\title{
Following the Roman Army between the Southern Foothills of the Cantabrian Mountains and the Northern Plains of Castile and León (North of Spain): Archaeological Applications of Remote Sensing and Geospatial Tools
}

\author{
Andrés Menéndez Blanco ${ }^{1, * \mathbb{C}}$, Jesús García Sánchez ${ }^{2}$, José Manuel Costa-García ${ }^{3}{ }^{(\mathbb{D}}$, \\ João Fonte ${ }^{4} \mathbb{D}$, David González-Álvarez ${ }^{5}$ (D) and Víctor Vicente García ${ }^{3}$ (D) \\ 1 Independent Researcher and Archaeologist, Ayande, 33880 Asturias, Spain \\ 2 Archaeology Institute of Mérida (CSIC-Government of Extremadura), Plaza de España 15, \\ 06800 Mérida, Extremadura, Spain; j.garcia@iam.csic.es \\ 3 Department of History, University of Santiago de Compostela, Praza da Universidade 1, \\ 15782 Santiago de Compostela, Galicia, Spain; josemanuel.costa@usc.es (J.M.C.-G.); \\ victor.vicente.garcia@usc.es (V.V.G.) \\ 4 Department of Archaeology, University of Exeter, Laver Building, North Park Road, Exeter EX4 4QE, UK; \\ j.fonte3@exeter.ac.uk \\ 5 Institute of Heritage Sciences, Spanish National Research Council (Incipit-CSIC), Avenida de Vigo, s/n, \\ 15705 Santiago de Compostela, Galicia, Spain; david.gonzalez-alvarez@incipit.csic.es \\ * Correspondence: andresmenendezblanco@gmail.com; Tel.: +34-680-718-734
}

Received: 19 October 2020; Accepted: 27 November 2020; Published: 2 December 2020

\begin{abstract}
Sixty-six new archaeological sites have been discovered thanks to the combined use of different remote sensing techniques and open access geospatial datasets (mainly aerial photography, satellite imagery, and airborne LiDAR). These sites enhance the footprint of the Roman military presence in the northern fringe of the River Duero basin (León, Palencia, Burgos and Cantabria provinces, Spain). This paper provides a detailed morphological description of 66 Roman military camps in northwestern Iberia that date to the late Republic or early Imperial eras. We discuss the different spatial datasets and GIS tools used for different geographic contexts of varied terrain and vegetation. Finally, it stresses out the relevance of these novel data to delve into the rationale behind the Roman army movements between the northern Duero valley and the southern foothills of the Cantabrian Mountains. We conclude that methodological approaches stimulated by open-access geospatial datasets and enriched by geoscientific techniques are fundamental to understand the expansion of the Roman state in northwestern Iberia during the 1st c. BC properly. This renewed context set up a challenging scenario to overcome traditional archaeological perspectives still influenced by the cultural-historical paradigm and the pre-eminence of classical written sources.
\end{abstract}

Keywords: Roman military archaeology; remote sensing; geosciences; archaeological survey; satellite imagery; aerial photography; airborne LiDAR; Iberian Peninsula

\section{Introduction}

By the time the Cantabrian Wars (29-19 BC) were over, the last territories in the Iberian Peninsula independent to the Roman state ceased to exist [1]. The first two decades of the 21st century revolutionised our knowledge of the Roman expansion and the role of the Roman army in northwestern Iberia. This is a dynamic research topic resulting from the technological developments and the 
accumulation of discoveries. Due to the large volume of new data, northwestern Iberia stands out among other European regions in the more recent discussions within the academic field of Roman military archaeology, as a relevant area for the experimentation of new methodological and theoretical proposals.

The growing interest in this area comes from several exceptional reasons within the European research context. Undoubtedly, the increasing availability of open access geospatial datasets in Spain and Portugal [2-5] have had a substantial impact on the development of innovative methods applied by interdisciplinary projects. Approaches making extensive use of remote sensing techniques and relying on spatial analyses have contributed not only to generate new data but also to understand them as a whole [6,7].

New and diverse methodological approaches have been adopted in the study area as a result of new technologies. We must emphasise new perspectives on asymmetrical conflicts between pre-modern societies and Mediterranean states, the consideration of active agencies for local indigenous actors -also recognizing their internal diversity - and the overcoming of the old and rigid 'Romanisation' concept after assuming post-colonial critiques [8-15]. Just a few decades ago, the study of the asymmetrical confrontation between the local indigenous communities in northwestern Iberia and the Roman army was mainly supported by the reading of ancient written sources [16]. Today, the archaeological datasets produced by up-to-date methods and techniques are the primary source to approach this historical process [17-19].

Particularly during the last decade, new research has led to the identification and analysis of a large number of new sites related to the presence of the Roman army in northwestern Iberia [20-25] (Figure 1). In addition, archaeological fieldwork projects were conducted in different territories, providing us with much novel information about Roman camps in this region [21,25-31]. These new data shed light on areas of northwestern Iberia where the presence of the Roman army was presumed to be limited, or even non-existent [32-34]. For instance, some routes recurrently used by large military contingents have been identified across the bordering, mountainous territories of modern-day Asturias and Galicia [30,35,36]. These routes reproduce geographical and strategical patterns previously documented to the east, in the mountains of Cantabria [37-40]. Also, Roman camps which could date from late Republican (late 2nd c. BC and 1st c. BC) or early Imperial (late 1st c. $\mathrm{BC}$ and early-1st c. AD) times have been recently detected in the gentler topographies of central and western Galicia, as well as northern Portugal [6,41].

Despite these advances, there are still extensive areas within northwestern Iberia where available archaeological data are scarce for assessing the Roman military presence. For example, the present-day provinces of León, Palencia, and Burgos (within the Spanish autonomous community of Castile and León) correspond with a void in the archaeological distribution of military sites. The phenomenon is particularly evident in the valley areas coming down from the southern foothills of the Cantabrian Mountains, or the vast plains of the Northern Spanish Plateau. The situation could be related to the lack of research, as well as the limited application of remote sensing techniques and digital methods adopted from Geosciences [42], which are deeply transforming Roman military archaeology in northwestern Iberia. This paper fills a noticeable gap through a spatial analysis of the northern territories of León, Palencia, and Burgos, as well as the southernmost area of Cantabria (Figures 2 and 3 ). Renewed research strategies provide us with the opportunity to evaluate the potential of methodologies previously developed by some of us in other areas within northwestern Iberia $[2,43,44]$. This way, we can assess the diversity of solutions adopted by the Roman army when deploying across these diverse landscapes. To achieve these objectives, we have applied a reliable, large-scale survey method in the study area using innovative geospatial datasets and tools. 


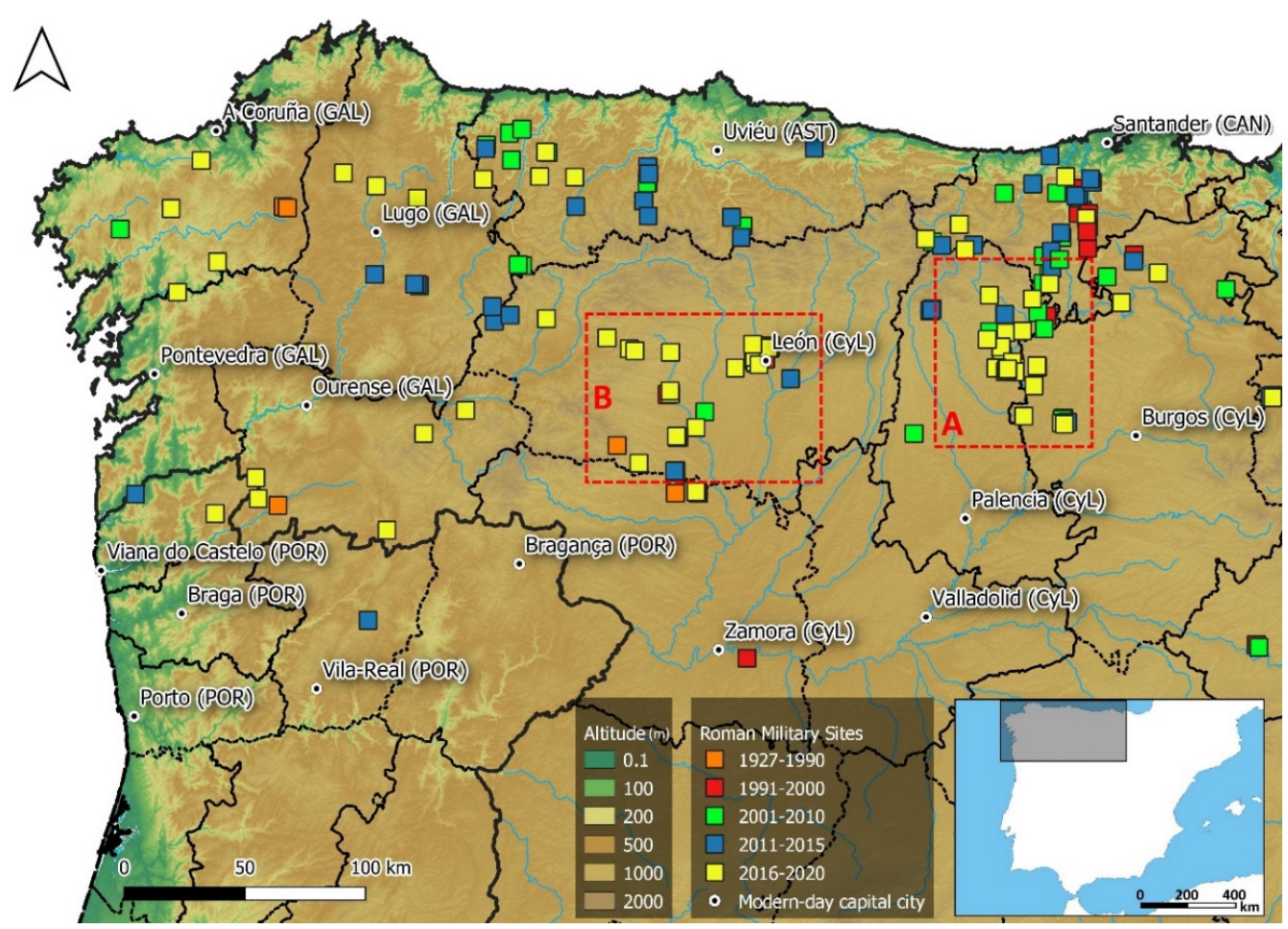

Figure 1. Roman military sites archaeologically attested in northwestern Iberia according to their discovery/publication date. The major administrative units mentioned in this paper are Galicia (GAL), Asturias (AST), Castile and León (CyL), Cantabria (CAN) and northern Portugal (POR). The Castilian (A) and Leonese (B) study areas delimited in red.

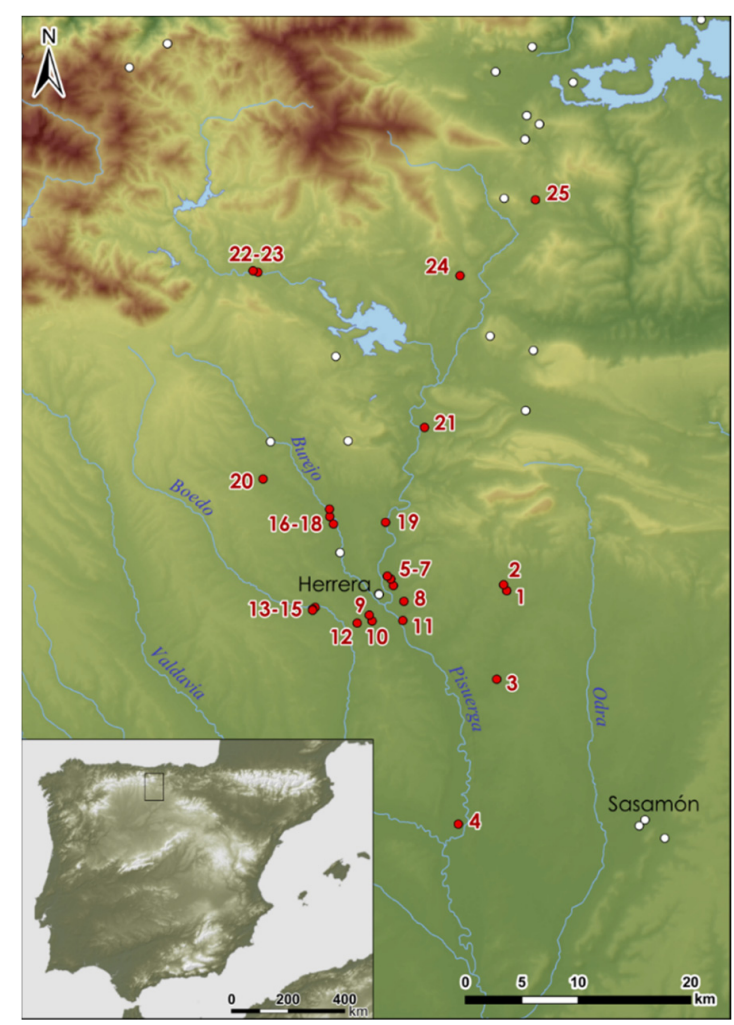

Figure 2. Roman military presence in northern Castile (study area 1). Sites included in this study coloured in red. The numbering follows their order of appearance in the text, also summarised in Tables 1 and 2. 


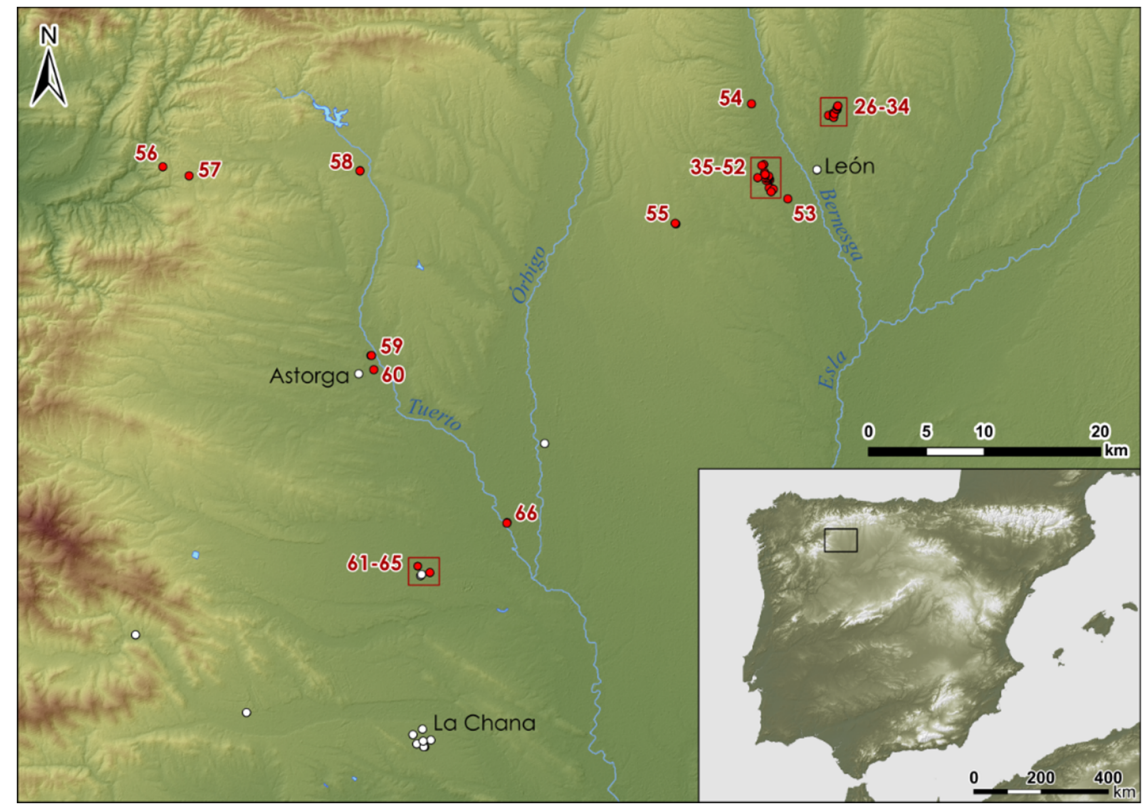

Figure 3. Roman military presence in León (study area 2). Coloured in red, sites included in this study. The numbering follows their order of appearance in the text, also summarised in Tables 1 and 3.

The increasing availability of open-access geospatial datasets is determinant for building up new archaeological narratives on the Roman conquest of northwestern Iberia. The availability of several open-access datasets (aerial photography, satellite imagery, and airborne LiDAR—Light Detection and Ranging) enable a different, but complementary, approach to those based on the extensive use of oblique aerial photography [19,45]. The use of UAVs (Unmanned Aerial Vehicle) for aerial data acquisition [46-48] and GIS for spatial analysis [49-51] were also incorporated to our landscape archaeology approach.

The extensive dataset presented and analysed here will allow us to transform our understanding of the Roman military deployment in northwestern Iberia. This new data will help us to interpret the movements of Roman troops across the landscape and examine the relationships they established with indigenous communities, named Vaccaei, Turmogi, Cantabri, Astures and Callaeci, according to the Greek and Latin sources (Strab. Geog. 3). To do so, we will first characterise and discuss the current knowledge regarding the archaeological investigation of Roman military sites in northwestern Iberia, briefly focusing on the relevance of remote sensing techniques and digital methods [52]. Later, we will present the materials and methods used in our investigation, in connection with the aims intended to be accomplished. The central and more extensive section in this paper will be the detailed description of the 66 new Roman military sites discovered in the study area. We will discuss their landscape context, morphological characteristics, state of preservation, and the implications of these findings for regional research. Finally, we will discuss the relevance and significance of our results and future research possibilities.

\section{Case Study and Research Context}

Only a handful of Roman military sites were known in northwestern Iberia by the late 1980s [53,54]. The development of urban archaeology led to the discovery of permanent military bases from early Imperial times in some cities of the Northern Spanish Plateau during the following decade, attracting the attention of a new generation of researchers [55,56]. The importance of sites such as Herrera de Pisuerga, León, or Astorga as pivotal points of the early Imperial military deployment will be discussed in the following sections.

However, a digital revolution was undergoing on the eve of the new century. The systematic archaeological survey of the eastern sector of the Cantabrian Mountains using conventional methods resulted in the location of temporary sites that could be linked with ancient war episodes $[37,57]$. 
Beyond their intrinsic importance, these findings spurred a new wave of discoveries in northwestern Iberia that continues to this day, fuelled by the potential of remote sensing techniques $[6,7,58]$. In short, the number of Roman military sites in the area has increased eightfold in less than 20 years, and the focus of research has gravitated from permanent sites to temporary fortifications.

However, the diverse landscape of northwestern Iberia has proved challenging for extensive archaeological prospection, since materials, methods, and sampling strategies have to be adapted to every sub-region. At the same time, this diversity brings quite different preservation and visibility conditions for archaeological materiality remaining from the Roman military sites, since temporary occupations usually left fragile and subtle traces on the surface [59]. The ditches or the earth and stone ramparts protecting these fortifications have been filled in and flattened, while other organic and inorganic materials resulting from military occupation have suffered heavily over time.

Recently, indigenous pre-Roman societies within northwestern Iberia have been characterised by scholars of Iron Age society by their diversity considering their cultural, productive and social traits [8,60-62], meaning that the interaction, conquest and further assimilation of their territories by the Roman state might have been accomplished through different processes at different times $[63,64]$. Moreover, fragmentation is also a characteristic of the archaeological traditions in Spain, where territorial isolation regarding scientific dynamics and heritage management set up another handicap for extensive research initiatives and broad discussions [65]. That explains the uneven progress of the discipline in the different territories and why our study area has suffered from this process.

Here, we focus on the transition zone between the plains within the northern Duero basin and the southern foothills of the Cantabrian Mountains. In the modern-day provinces of Burgos, Palencia and Cantabria we investigated some upper valleys within the Pisuerga basin, such as those formed by the Odra, Burejo, Boedo and Pisuerga rivers. At the same time, we also conducted research in the central area of the modern-day province of León, within some subsidiary valleys to the Esla basin, where we followed the central section of the Bernesga, Órbigo and Tuerto rivers. These valleys show a gentle topography in their ascent to the Cantabrian Mountains (to the north) and the Leonese Massif (to the west).

The northern Duero basin offers optimal conditions for aerial archaeology. Land division underwent a major reorganisation from 1952 onwards, leading to the transformation of small properties into more extensive estates. In addition, agriculture in this area is mostly oriented towards cereal crops, generating continuous and homogenous surfaces of vegetation sensitive to drought. That is precisely the kind of landscape that favours the detectability of underground structures by using remote sensing techniques [66-68]. However, other agricultural practices can be found across our study area, which generate more challenging landscapes for the use of remote sensing techniques in our archaeological surveys. Thus, irrigation and crop rotation generate more complex and variable landscapes along some irrigated fluvial valleys, including corn, legumes, and fodder cultivation, so cropmarks and soil marks related to archaeological sites may appear differently every agrarian season. Moreover, marginal agrarian zones across these landscapes are exploited for pastoralism, so shrubs and pastures are also present within our study area, acting as a clear limit to aerial and satellite archaeology. Finally, the foothills of the Cantabrian Mountains and the Leonese Massif underwent aggressive reforestation policies in the last decades, which might hide or even destroy the ancient traces left behind by the Roman legions.

To date, marching camps have been a relatively rare archaeological feature identified in the Northern Spanish Plateau. Although the analysis of historical, state-wide vertical aerial coverages provided some excellent results since the 1960s [69-71], the long-standing tradition of aerial photography in the River Duero basin is reliant on oblique aerial imagery. This has led to the detection of some temporary camps $[54,72,73]$ among other interesting archaeological sites, such as Iron Age enclosures, Roman rural settlements, and traces of Roman urban layouts [45,74-77]. However, the broad scope of such studies was detrimental to an in-depth understanding of local phenomena. Usually, aerial photography was a goal in itself, and a tool rarely supplemented with data acquired on the surface and through pedestrian survey. This aspect has proven essential when it comes to the study of the Roman military presence [19,78-80]. 
The potential of other datasets (such as recent vertical aerial coverages, satellite imagery or airborne LiDAR) to identify and study Roman military sites in this area has been explored [81-83], although never implemented systematically. Not surprisingly, LiDAR technology has proven its true potential in less anthropised, peripheral areas [25,84] similar to the mountainous zones that have capitalised the research in Roman military archaeology in the last decades. However, there were no apparent reasons for the lack of success of aerial and satellite imagery, beyond the absence of focused and sustained archaeological research and systematic survey.

After thoroughly mapping the evidence available to date of the Roman army in northwestern Iberia, we detected several gaps between areas of known active military presence during the Roman times. The lower density of Roman camps in large regions of the Northern Iberian Plateau or the foothills of the Cantabrian Mountains and the Leonese massif was particularly remarkable. A systematic survey of these territories was carried out in 2019-2020, aiming to identify new archaeological evidence to create a more detailed picture of Roman military activity in northwestern Iberia. The experience gathered as a result of the research strategies developed by members of our team in Asturias, Galicia, Northern Portugal, the mountains of León or the Odra-Pisuerga area (Burgos) within the last decade $[6,43,44]$ have supported this initiative.

As a result, more than 60 archaeological sites that can be related to the Roman army have been discovered in the study area. These data constitute a game-changing referent for the analysis of the Roman military presence in northwestern Iberia and can help the reassessment of the historical narratives on the conquest of an area inhabited in pre-Roman times by different indigenous groups, such as the Turmogi, the Vaccaei, the Cantabri, and the Astures. However, the in-depth understanding of the impact of the Roman expansion on these territories demands a more ambitious study whose theoretical framework feeds on the contributions of conflict and postcolonial archaeologies [85-87].

\section{Materials and Methods}

In recent decades, the increasing accessibility to new geospatial datasets has supported the development of innovative remote sensing approaches in this region (Table 1). Following INSPIRE European policies (INfrastructure for SPatial InfoRmation in Europe: https://inspire.ec.europa.eu/), the Spanish national and regional governments have provided public access to several series of aerial coverages generated within the framework of the PNOA programme (Plan Nacional de Ortofotografía Aérea: http://pnoa.ign.es/), supported by the IGN (Instituto Geográfico Nacional: http://www.ign.es/). This includes diverse RGB (Red, Green, and Blue) and NIR (Near Infrared) series of airborne orthophotography with 25-50 cm resolution, taken between 2004 and 2018 at different times of the year, depending on the region. Besides, some historical aerial coverages are accessible: USAF (United States Air Force) Series A (1945-1946) and B (1956-1957), Interministerial Flight or IRyDA (Instituto Nacional de Reforma y Desarrollo Agrario) (1973-1986), Nacional Flight (1980-1986), and Quinquenal Flight (1998-2003) (resolution and specifications: http://pnoa.ign.es/pnoa-historico). Although they were not explicitly designed for archaeological purposes, these datasets sustain diachronic approaches to the study of archaeological landscapes.

Other online platforms such as Google Earth, Bing Maps, and Apple Maps have gained popularity in archaeological research by granting access to satellite imagery (and some specific aerial coverages) generated by private companies (GeoEye, Pleiades or QuickBird) $[88,89]$. The overall quality, actualisation rate, and global coverage of these datasets allowed researchers to extract information from across unprecedented scales. UAV-based aerial data acquisition is another recent development. However, it favours the in-depth documentation of single sites, not being yet suitable for exploratory research programmes over large areas [46-48,90].

Finally, airborne LiDAR technology is one of the latest scientific additions to an already extensive range of technical solutions. For the moment, there is one LiDAR coverage available for Castile and León (2010) and another one for Cantabria (2012) (https://pnoa.ign.es/estado-del-proyecto-lidar). These data have an average ground returns of 0.5 points $/ \mathrm{m}^{2}$. Despite its potential for the detection and characterisation of Roman military sites elsewhere [2,91-94], the technology shows certain limitations in zones with anthropogenic landscape modifications and extensive agricultural areas [81,83]. 
Table 1. Geospatial datasets used in this work and its effectiveness to detect archaeological features considering the following areas: Odra Pisuerga (1), Boedo-Ojeda (2), Montaña palentina (3), Bernesga (4), Tuerto (5), Villamontán (6), Sariegos, Trobajo, Sueros and Astorga (7).

\begin{tabular}{|c|c|c|c|c|c|c|}
\hline Source & Source Type & Date & GSD $^{4}$ & Open Access & Effectiveness & 5 Provider \\
\hline Google Earth (2) & Satellital & 17 June 2019 & $42 \mathrm{~cm}$ & Yes & $1,2,3$ & GeoEye (sat.) \\
\hline $\begin{array}{l}\text { Lidar 1st } \\
\text { Coverage (2) }\end{array}$ & Airborne LiDAR & 2010-2011 & $0.5 \mathrm{pt} / \mathrm{m}^{2}$ & Yes & 1,3 & CNIG \\
\hline PNOA RGB $(2,3)$ & $\begin{array}{c}\text { Airborne } \\
\text { orthophoto }\end{array}$ & 2009 & $22 \mathrm{~cm}$ & Yes & $1,2,3$ & CNIG \\
\hline PNOA NIR (3) & $\begin{array}{c}\text { Airborne } \\
\text { orthophoto }\end{array}$ & 2009 & $22 \mathrm{~cm}$ & Yes & 1,3 & CNIG \\
\hline PNOA RGB $(2,3)$ & $\begin{array}{l}\text { Airborne } \\
\text { orthophoto }\end{array}$ & 2017 & $35 \mathrm{~cm}$ & Yes & $1,2,4,5$ & CNIG \\
\hline PNOA RGB $(2,3)$ & $\begin{array}{l}\text { Airborne } \\
\text { orthophoto }\end{array}$ & 2014 & $45 \mathrm{~cm}$ & Yes & $2,3,6$ & CNIG \\
\hline PNOA RGB $(2,3)$ & $\begin{array}{c}\text { Airborne } \\
\text { orthophoto }\end{array}$ & 2011 & $45 \mathrm{~cm}$ & Yes & 2,7 & CNIG \\
\hline PNOA RGB $(2,3)$ & $\begin{array}{c}\text { Airborne } \\
\text { orthophoto }\end{array}$ & 2007 & $45 \mathrm{~cm}$ & Yes & 2 & CNIG \\
\hline PNOA RGB $(2,3)$ & $\begin{array}{c}\text { Airborne } \\
\text { orthophoto }\end{array}$ & 2006 & $50 \mathrm{~cm}$ & Yes & 4,5 & CNIG \\
\hline PNOA RGB $(2,3)$ & $\begin{array}{c}\text { Airborne } \\
\text { orthophoto }\end{array}$ & 2008 & $25 \mathrm{~cm}$ & Yes & 4,5 & CNIG \\
\hline PNOA RGB $(2,3)$ & $\begin{array}{l}\text { Airborne } \\
\text { orthophoto }\end{array}$ & 2010 & $50 \mathrm{~cm}$ & Yes & 4 & CNIG \\
\hline Google Earth (4) & Satellital & 13 September 2017 & $<50 \mathrm{~cm}$ & Yes & 4 & CNIG \\
\hline Google Earth (4) & Ortho & 08 September 2011 & $<50 \mathrm{~cm}$ & Yes & 4 & Maxar Tech. \\
\hline Interministerial (2) & $\begin{array}{c}\text { Airborne } \\
\text { orthophoto }\end{array}$ & 1973-1986 & 50 & Yes & 4,5 & CNIG \\
\hline Bing (6) & Ortho & Not provided & $<30 \mathrm{~cm}$ & Yes & 4,5 & Airbus (sat.) \\
\hline Google Earth (4) & Ortho & 07 June 2016 & $<50 \mathrm{~cm}$ & Yes & 4 & CNIG \\
\hline $\operatorname{SigPac}(2,3)$ & $\begin{array}{c}\text { Airborne } \\
\text { orthophoto }\end{array}$ & 2002 & $50 \mathrm{~cm}$ & Yes & 4,5 & $\mathrm{CNIG}$ \\
\hline Serie B (2) & $\begin{array}{l}\text { Airborne } \\
\text { orthophoto }\end{array}$ & 1956 & $125 \mathrm{~cm}$ & Yes & 4,5 & $\mathrm{CNIG}$ \\
\hline Nacional (2) & $\begin{array}{l}\text { Airborne } \\
\text { orthophoto }\end{array}$ & 1984 & $65 \mathrm{~cm}$ & Yes & 4 & CNIG \\
\hline Google Earth (4) & Satellital & 11 August 2007 & $<50 \mathrm{~cm}$ & Yes & 4 & CNIG \\
\hline Google Earth (4) & Satellital & 18 March 2020 & $<50 \mathrm{~cm}$ & Yes & 4 & Maxar Tech. \\
\hline Serie A (5) & $\begin{array}{l}\text { Airborne } \\
\text { orthophoto }\end{array}$ & 1945-1946 & $1-2 \mathrm{~m}$ & Yes & 5 & CNIG \\
\hline PNOA RGB $(2,3)$ & $\begin{array}{l}\text { Airborne } \\
\text { orthophoto }\end{array}$ & 2004 & $50 \mathrm{~cm}$ & Yes & 5 & CNIG \\
\hline Google Earth (4) & Satellital & 12 June 2009 & $<50 \mathrm{~cm}$ & Yes & 5 & Maxar Tech. \\
\hline Google Earth (4) & Satellital & 29 May 2009 & $<50 \mathrm{~cm}$ & Yes & 5 & Maxar Tech. \\
\hline Google Earth (4) & Satellital & 13 September 2017 & $<50 \mathrm{~cm}$ & Yes & 5 & Maxar Tech. \\
\hline Google Earth (4) & Satellital & 19 September 2010 & $<50 \mathrm{~cm}$ & Yes & 5 & Maxar Tech. \\
\hline Google Earth (4) & Satellital & 23 August 2007 & $<50 \mathrm{~cm}$ & Yes & 5 & Maxar Tech. \\
\hline Google Earth (4) & Satellital & 1 June 2009 & $<50 \mathrm{~cm}$ & Yes & 5 & Maxar Tech. \\
\hline Google Earth (4) & Satellital & 16 June 2015 & $<50 \mathrm{~cm}$ & Yes & 5 & Maxar Tech. \\
\hline UAV (7) & $\begin{array}{l}\text { Photogrammetric } \\
\text { Flights }\end{array}$ & June 2020 & $<5 \mathrm{~cm}$ & No & 4,5 & $\begin{array}{c}\text { J. M. } \\
\text { Costa-García }\end{array}$ \\
\hline
\end{tabular}


Given their temporary nature and the ephemeral and almost invisible materiality that makes up the Roman military camps [57], these technologies are particularly suited for their identification. However, the variable potential and limitations of these tools and datasets for the survey of archaeological landscapes explain why the articulation of multi-scalar methodologies involving their combined use is critical to document these sites in northwestern Iberia. Moving from our previous research experiences $[2,18,43,44,95]$, this survey has developed that kind of methodological approach (see Figure 4).

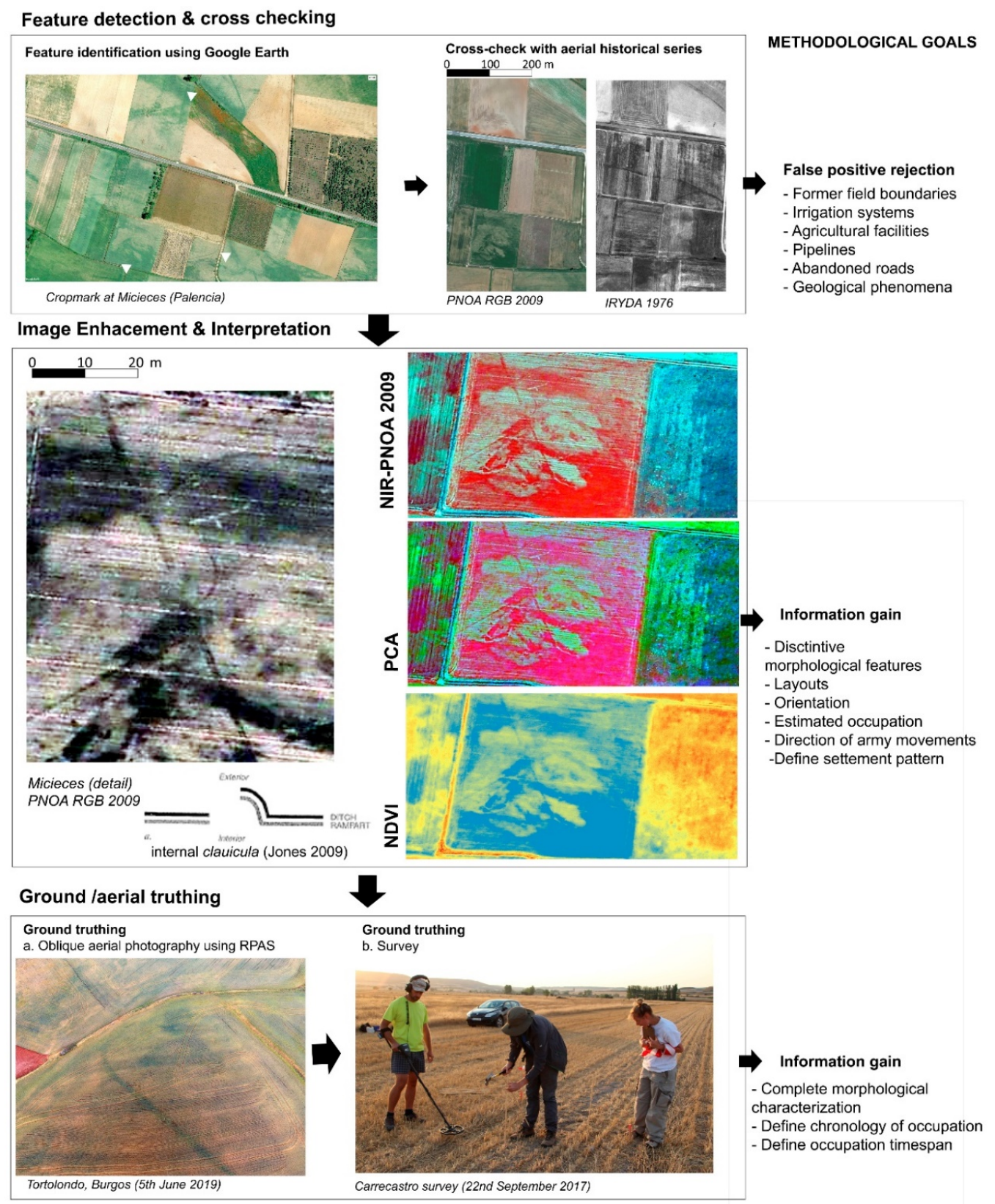

Figure 4. Methodological workflow.

Despite the limitations already noted, we processed the available LiDAR cloud points provided by the IGN (Instituto Geográfico Nacional, the Spanish National Geographic Institute), supporting the generation of $1 \mathrm{~m}$ digital terrain models (DTMs) and different derived visualisations using LAStools (rapidlasso GmbH), SAGA GIS 2.1.4 and Relief Visualization Toolbox (RVT) 2.2.1 (ZRC SAZU) software [96-102]. Unfortunately, the airborne LiDAR has low-ground returns, varying from 0.5 to 2 returns per $\mathrm{m}^{2}$. Low ground visibility often proves challenging for archaeological prospection [2]. 
However, the models assisted the detection of some archaeological structures in upland areas or zones characterised by its dense vegetation cover $[98,103]$. Here, archaeological microtopographies have survived to a certain degree [2].

The use of heavy machinery for forestry activities in mountainous areas has impacted negatively on the preservation of the archaeological features, to the point that many of them have been completely razed in the last decades. Historical aerial photos and satellite archival imagery [104-106] are instrumental for the reconstruction of archaeological landscapes significantly altered by different anthropogenic activities. This is sometimes the only option to digitally retrieve the lost materiality. That is the case of several zones in El Bierzo area (León), where factors such as the opening of firebreaks and tracks or the reforestation activities have contributed negatively to the preservation of the archaeological sites [25,69].

In open areas with more intense agricultural activity such as the Duero basin, aerial photography, and satellite imagery with different temporal, spatial and spectral resolution, have allowed us to identify numerous Roman military sites. In these zones, the archaeological remains do not have a positive topographical expression on the ground. Since the structures have been completely erased, the only way to identify them is by the marks formed within the different crops, named cropmarks.

Two main factors contribute to the formation of cropmarks [107-111]. The first one is the differential growth of crops caused by soil moisture deficit, which accentuates the visibility of buried archaeological remains. This phenomenon varies considerably according to soil's pedology: the better the drainage, the more likely the appearance of cropmarks. Second, the type of crop can influence the formation of these traces. Cereals are the most positive contributors in this respect, but industrial crops and pastures also produce sharp images of buried remains in aerial and satellite imagery. Depending on the time of acquisition of the aerial or satellite images, the living cycle of the crop and the conditions mentioned above, these cropmarks might be more or less visible-if not visible at all.

Even considering its limitations regarding image resolution and data actualisation rate, imagery provided by Google Earth has proven useful for archaeology in similar agricultural contexts [112,113]. In Burgos and Palencia, the latest available satellite coverage became essential for the detection of previously unnoticed features, since the pictures were taken during an optimal moment of the phenological cycle of cereal crops (17 June 2019)—just a few days after our UAV-based aerial survey took place [43]. Its combined use with other datasets has proven to be effective in the plains and open valleys of the Northern Iberian Plateau. This way, the historical aerial photography-namely the USAF and IRYDA flights-served as a master key for discarding the traces of former land parcelling while the PNOA series-both the RGB and NIR bands-helped to dismiss more recent agrarian transformations.

We also explored multispectral imagery using the datasets from the PNOA series and different spectral bands [114]. The combined use of RGB and NIR bands, allowed us to highlight the visibility of archaeological features through the calculation of vegetation indexes-such as NDVI (Normalised Difference Vegetation Index)-or image statistics like PCA (Principal Component Analysis) [115,116]. To this end, we enhanced the visualisation of NIR and RGB orthophotographs by equalising the histograms to the raster extent [77]. Far from being mere cross-checking tools, some aerial series enhanced feature detection. That is the case of PNOA RGB-NIR 2009 coverage, which allows us to use a broader range of the electromagnetic spectrum to spot cropmarks [117]. Another method explored in a particular case-study (Tortolondro, Burgos) is to combine our UAV-derived orthophotography with PNOA NIR images [118,119].

The morphological analysis of the evidence, based on the available archaeological data and our research experience $[6,17,59,120-123]$, led to the identification and characterisation of some Roman military sites. A complete record of these findings is summarised in the results section. Several discarded features, products of recent anthropogenic activities, were also stored in separate libraries as false-positive traces. Due to their similarity to the ancient structures, they could contribute to training computer-assisted detection systems in future machine-learning projects [124-126].

All the features analysed in this paper were processed in a GIS environment (using QGIS 3.12 and ArcGIS 10.7.). These anomalies were digitized, measured, and classified using morphometrical 
categories (such as total dimensions, defensive perimeter length, total estimated surface, orientation, or the presence of recognisable entrances). LiDAR-derived DTMs and visualisations (namely local relief model, resampling filter, and multi-directional hillshade [96,97]) supported the development of basic spatial analyses to characterise the settlement pattern of the sites [6,122].

Ground-truthing was a crucial step in data validation, and this process was enhanced by high-detail photogrammetric surveys [127]. Thousands of vertical and oblique aerial photographs were taken using UAVs to support the generation of digital surface models (DSM) and orthoimages $[46,117,128,129]$. However, these preliminary observations made in the field constitute the first phase of an in-depth archaeological study already developed at other sites [27,36,43], but not yet here. This methodological approach is complemented with different archaeological scientific techniques involving intra and off-site surveying, often comprising metal-detecting [130,131], geophysics (GPR, magnetometer [91,132-134]), and targeted keyhole test pits or evaluation trenches to obtain samples for absolute dating and palaeoenvironmental sampling $[27,135]$.

\section{Results}

Among many other archaeological features, 66 possible Roman military sites were detected in the study areas during our survey (Figures 2 and 3). We briefly describe them in the section, although further morphotypological and planimetric details can be found in Tables 2 and 3 as well as Figure 5 .

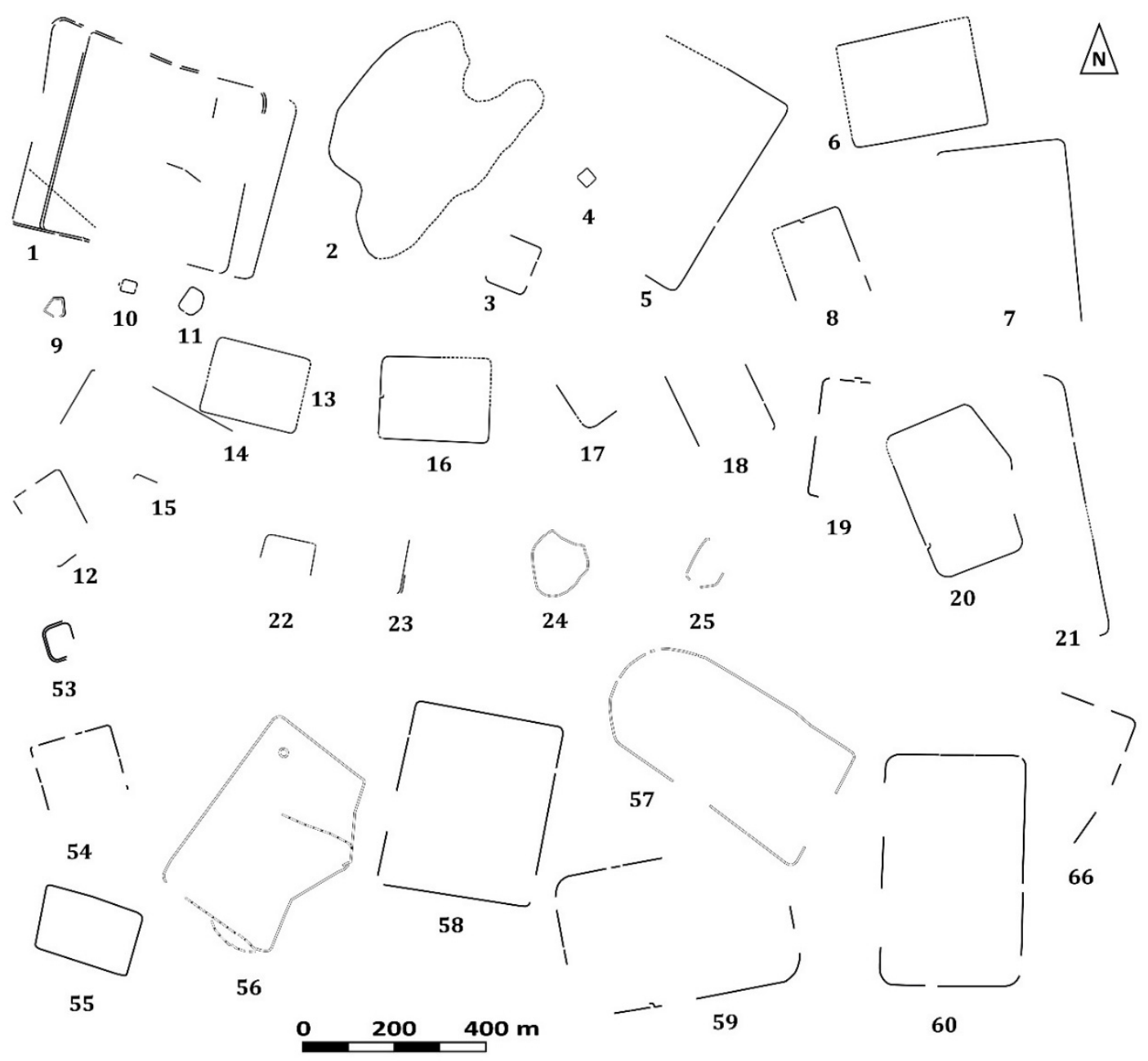

Figure 5. Comparative planimetry of the some of the sites analysed in this study (the major clusters have been represented separately: Figures 9, 13, 14 and 17). The numbering follows their order of appearance in the text, also summarised in Tables 2 and 3. 
Table 2. Roman military sites in northern Castile (study area 1).

\begin{tabular}{|c|c|c|c|c|c|c|c|c|c|c|}
\hline $\mathrm{N}^{\circ}$ & Name & Layout & $\begin{array}{c}\text { Dimensions } \\
(\mathrm{m})\end{array}$ & Size (ha) & $\begin{array}{c}\text { Defensive } \\
\text { Perimeter }(\mathrm{m})\end{array}$ & $\begin{array}{c}\text { Slope (Mean } \\
\text { in Degrees) }\end{array}$ & Defences & Ditches & Gates & $\begin{array}{l}\text { Hypothetical } \\
\text { Garrison }\end{array}$ \\
\hline \multirow{2}{*}{1} & Tortolondro (int) & Irregular playing-card & $457 \times 421$ & 18.18 & 1641 & 4.55 & Cropmark & 2 & - & $8900-11,500$ (min) \\
\hline & Tortolondro (ext) & Irregular playing-card & $570 \times 470$ & 23.87 & 1930 & 4.16 & Cropmark & 2 & - & $11,500-15,100(\mathrm{~min})$ \\
\hline 2 & Matimocha & Irregular & $505 \times 354$ & 13.30 (est) & 1555 & 1.93 & Cropmark & 1 & - & $6500-8500$ \\
\hline 3 & La Calzada & Playing-card & $113 \times 93$ & 0.94 & 273 & 2.09 & Cropmark & 1 & - & $450-600$ \\
\hline 4 & San Andrés & Square & $33 \times 32$ & 0.1 & 121 & 4.01 & Cropmark & 1 & - & $50-60$ \\
\hline 5 & Herrera 1 & Playing-card & $482 \times 318$ & $9.4(\min )$ & $860(\min )$ & 2.16 & Cropmark & 1 & - & $3100-6000$ (min) \\
\hline 6 & Herrera 2 & Playing-card & $405 \times 284$ & $11.13(\min )$ & $676(\min )$ & 1.74 & Cropmark & 1 & - & $5400-7000(\mathrm{~min})$ \\
\hline 7 & Herrera 3 & Playing-card & $304 \times 240$ & 7.02 (est) & 1032 (est) & 1.27 & Cropmark & 1 & - & $3400-4500$ \\
\hline 8 & Herrera 4 & Playing-card & $206 \times 160$ & 3.2 (est) & 707 (est) & 2.93 & Cropmark & 1 & 1 (Int. clauicula) & $1500-2000$ \\
\hline 9 & Las Pardas 1 & Playing-card & $33 \times 27$ & 0.08 & 109 & 1.54 & Cropmark & 1 & 1 (Titulus) & $140-150$ \\
\hline 10 & Las Pardas 2 & Irregular playing-card & $57 \times 46$ & 0.22 & 174 & 4.59 & Cropmark & 1 & 1 & $100-140$ \\
\hline 11 & Valdemiranda & Pentagonal & $43 \times 27$ & $0.08(\mathrm{~min})$ & $72.3(\mathrm{~min})$ & 1.4 & Cropmark & 1 & - & $40-55(\min )$ \\
\hline 12 & Calahorra de Boedo & Irregular playing-card & $185 \times 123$ & 2.6 (est) & 571 (est) & 2.7 & Cropmark & 1 & - & $1250-1650$ \\
\hline 13 & Páramo de Boedo 1 & Playing-card & $216 \times 169$ & 3.6 & 471 & 1.09 & Cropmark & 1 & - & $1700-2300$ \\
\hline 14 & Páramo de Boedo 2 & Playing-card & $340 \times 176$ & $5.2(\mathrm{~min})$ & 474 & 1.19 & Cropmark & 1 & - & $2500-3300$ (min) \\
\hline 15 & Páramo de Boedo 3 & Playing-card (?) & $52 \times 12$ & $0.06(\mathrm{~min})$ & 58 & 1.32 & Cropmark & 1 & - & - \\
\hline 16 & La Vid de Ojeda 1 & Playing-card & $245 \times 183$ & 4.37 & 820 & 1.54 & Cropmark & 1 & 1 (Int. clauicula) & $2100-2800$ \\
\hline 17 & La Vid de Ojeda 2 & Playing-card (?) & $119 \times 74$ & $0.92(\min )$ & 189 (min) & 1.51 & Cropmark & 1 & - & $450-600$ (min) \\
\hline 18 & La Vid de Ojeda 3 & Playing-card & $200 \times 171$ & $3.43(\mathrm{~min})$ & $517(\min )$ & 1.45 & Cropmark & 1 & - & $1700-2200(\mathrm{~min})$ \\
\hline 19 & La Charcona & Playing-card (?) & $258 \times 109$ & $2.54(\mathrm{~min})$ & 376 (min) & 1.96 & Cropmark & 1 & 1 (Titulus) & $1200-1600$ (min) \\
\hline 20 & Micieces & Irreg. Playing-card & $345 \times 246$ & 7.43 & 1069 & 1.73 & Cropmark & 1 & 1 (Int. clauicula) & $3500-4500$ \\
\hline 21 & La Capilla & Playing-card? & $416 \times 33$ & - & $433(\mathrm{~min})$ & 1.7 & Cropmark & 1 & - & - \\
\hline 22 & Ligüérzana 1 & Playing-card? & $116 \times 70$ & $0.76(\mathrm{~min})$ & 223 (min) & 1.2 & Cropmark & 1 & - & $350-500$ \\
\hline 23 & Ligüérzana 2 & Unknown & $122 \times 11$ & - & $120(\min )$ & 1.59 & Cropmark & 2 & - & - \\
\hline 24 & Nestar & Irregular & $150 \times 126$ & 1.23 & 417 & 7.62 & Earthwork & - & - & $600-800$ \\
\hline 25 & Matarrepudio & Unknown & $106 \times 74$ & 0.6 & 203 & 6.56 & Earthwork & - & - & $300-400$ \\
\hline
\end{tabular}


Table 3. Roman military sites in León (study area 2).

\begin{tabular}{|c|c|c|c|c|c|c|c|c|c|c|}
\hline $\mathbf{N}^{\circ}$ & Name & Layout & $\begin{array}{l}\text { Dimensions } \\
(\mathrm{m})\end{array}$ & Size (ha) & $\begin{array}{c}\text { Defensive } \\
\text { Perimeter (m) }\end{array}$ & $\begin{array}{l}\text { Slope (Mean } \\
\text { in Degrees) }\end{array}$ & Defences & Ditches & Gates & $\begin{array}{l}\text { Hypothetical } \\
\text { Garrison }\end{array}$ \\
\hline 26 & Villaquilambre 1 & Playing-card & $194 \times 89(\mathrm{~min})$ & 1.32 (min) & $318(\min )$ & 1.85 & Cropmark & 1 & - & $650-850(\mathrm{~min})$ \\
\hline 27 & Villaquilambre 2 & Playing-card & $231 \times 209$ (est.) & 4.90 (est.) & 877 (est.) & 1.91 & Cropmark & 1 & - & $1700-2200(\mathrm{~min})$ \\
\hline 28 & Villaquilambre 3 & Playing-card & $152 \times 129(\mathrm{~min})$ & 1.22 (min) & $174(\min )$ & 1.59 & Cropmark & 1 & - & $600-800(\mathrm{~min})$ \\
\hline 29 & Villaquilambre 4 & Playing-card & $210 \times 127$ (est) & 2 (est) & 649 (est) & 1.54 & Cropmark & 1 & - & $1000-1300$ \\
\hline 30 & Villaquilambre 5 & Playing-card & $102 \times 80$ & 0.77 & 342 & 1.7 & Cropmark & 1 & - & $400-500$ \\
\hline 31 & Villaquilambre 6 & Playing-card & $170 \times 106$ (est.) & 1.65 (est) & 531 (est) & 1.56 & Cropmark & 1 & - & $800-1050$ \\
\hline 32 & Villaquilambre 7 & Playing-card & $63 \times 65$ (est.) & 0.39 (est) & 245 (est) & 1.42 & Cropmark & 1 & - & $200-250$ \\
\hline 33 & Villaquilambre 8 & Playing-card & $80 \times 77$ (est.) & 0.32 (est.) & 285 (est.) & 0.92 & Cropmark & 1 & - & $150-200(\mathrm{~min})$ \\
\hline 34 & Villaquilambre 9 & Playing-card & $203 \times 149$ (est.) & 2.98 (est.) & 677 (est.) & 1.17 & Cropmark & 1 & - & $850-1100(\mathrm{~min})$ \\
\hline 35 & Trobajo 1 & Playing-card & $109 \times 75$ & 0.80 & 345 & 1.41 & Cropmark & 1 & - & $400-500$ \\
\hline 36 & Trobajo 2 & Playing-card & $133 \times 90$ & 1.18 (est.) & 429 (est.) & 0.57 & Cropmark & 1 & - & $600-750(\mathrm{~min})$ \\
\hline 37 & Trobajo 3 & Playing-card & $110 \times 15(\mathrm{~min})$ & 0.16 (min) & $122(\mathrm{~min})$ & 1.33 & Cropmark & 1 & - & $80-100(\mathrm{~min})$ \\
\hline 38 & Trobajo 4 & Playing-card & $113 \times 75(\mathrm{~min})$ & 0.83 (min) & $252(\min )$ & 0.92 & Cropmark & 1 & - & $700-950$ \\
\hline 39 & Trobajo 5 & Playing-card & $107 \times 45(\mathrm{~min})$ & 0.46 (min) & $294(\min )$ & 1.12 & Cropmark & 1 & - & $650-850$ \\
\hline 40 & Trobajo 6 & Playing-card & $133 \times 85(\mathrm{~min})$ & $1.03(\mathrm{~min})$ & $208(\min )$ & 0.76 & Cropmark & 1 & - & $500-650$ (min) \\
\hline 41 & Trobajo 7 & Playing-card & $151 \times 96$ & 1.44 & 478 & 0.91 & Cropmark & 1 & - & $700-900$ \\
\hline 42 & Trobajo 8 & Playing-card & $85 \times 64$ & 0.53 (est) & 288 (est) & 1.52 & Cropmark & 1 & - & $250-350$ \\
\hline 43 & Trobajo 9 & Playing-card & $213 \times 128(\mathrm{~min})$ & $2.43(\mathrm{~min})$ & $429(\mathrm{~min})$ & 1.41 & Cropmark & 1 & - & $1300-1700$ \\
\hline 44 & Trobajo 10 & Playing-card & $105 \times 92(\min )$ & 1.07 (min) & $158(\min )$ & 0.99 & Cropmark & 1 & - & $500-650$ \\
\hline 45 & Trobajo 11 & Playing-card & $91 \times 70(\mathrm{~min})$ & 0.68 (min) & $154(\min )$ & 0.95 & Cropmark & 1 & - & $350-450$ \\
\hline 46 & Trobajo 12 & Playing-card & $100 \times 26(\mathrm{~min})$ & 0.54 (min) & 130 (min) & 0.86 & Cropmark & 1 & - & $250-350$ \\
\hline 47 & San Andrés 1 & Playing-card & $173 \times 139(\mathrm{~min})$ & 2.44 (min) & 296 (min) & 0.74 & Cropmark & 1 & - & $1200-1550$ \\
\hline 48 & San Andrés 2 & Playing-card & $166 \times 124$ & 2.06 & 563 & 1.41 & Cropmark & 1 & - & $1000-1300$ \\
\hline 49 & Oteruelo 1 & Playing-card & $206 \times 154$ & 3.17 (est) & 702 (est) & 1.63 & Cropmark & 1 & - & 1550-2000 \\
\hline 50 & Oteruelo 2 & Playing-card & $137 \times 102$ & 1.38 (est) & 466 (est) & 1.35 & Cropmark & 1 & - & $650-900$ \\
\hline
\end{tabular}


Table 3. Cont

\begin{tabular}{|c|c|c|c|c|c|c|c|c|c|c|}
\hline $\mathrm{N}^{\mathrm{o}}$ & Name & Layout & $\begin{array}{c}\text { Dimensions } \\
(\mathrm{m})\end{array}$ & Size (ha) & $\begin{array}{c}\text { Defensive } \\
\text { Perimeter }(\mathrm{m})\end{array}$ & $\begin{array}{c}\text { Slope (Mean } \\
\text { in Degrees) }\end{array}$ & Defences & Ditches & Gates & $\begin{array}{c}\text { Hypothetica } \\
\text { Garrison }\end{array}$ \\
\hline 51 & Oteruelo 3 & Playing-card & $71 \times 70$ & 0.50 (est) & 274 (est) & 0.8 & Cropmark & 1 & - & $250-300$ \\
\hline 52 & Oteruelo 4 & Playing-card & $75 \times 57$ & 0.43 (est) & 253 (est) & 1.53 & Cropmark & 1 & - & $200-250$ \\
\hline 53 & Oteruelo-Armunia & Playing-card & $84 \times 63$ & $\begin{array}{l}0.45 \text { (int) } \\
0.54 \text { (ext) }\end{array}$ & $\begin{array}{l}179 \text { (min) (int.) } \\
145 \text { (min) (ext) }\end{array}$ & 2.77 & Cropmark & 2 & - & $200-250$ \\
\hline 54 & Sariegos & Playing-card & $179 \times 144(\mathrm{~min})$ & $2.56(\mathrm{~min})$ & 461 (min) & 2.12 & Cropmark & 1 & - & $1250-1650$ \\
\hline 55 & $\begin{array}{l}\text { San Miguel del } \\
\text { Camino }\end{array}$ & Playing-card & $215 \times 145$ & 3.07 & 697 & 0.81 & Cropmark & 1 & - & $1500-1950$ \\
\hline 56 & La Silva 1 & $\begin{array}{c}\text { Irreg. } \\
\text { Playing-Card }\end{array}$ & $441 \times 320$ (est) & 12.37 & 1415 (est) & 5.02 & $\begin{array}{c}\text { Earthwork } \\
\text { (razed) }\end{array}$ & - & $\begin{array}{c}1 \\
\text { (Corridor) }\end{array}$ & $6000-7850$ \\
\hline 57 & La Silva 2 & $\begin{array}{c}\text { Irreg. } \\
\text { Playing-Card }\end{array}$ & $536 \times 275$ (est) & 13.74 & 1495 (est) & 3.43 & $\begin{array}{c}\text { Earthwork } \\
\text { (razed) }\end{array}$ & - & $1 ?$ & $6700-8700$ \\
\hline 58 & Sueros & Playing-card & $406 \times 334$ & 13.49 & 1447 & 0.58 & Cropmark & 1 & - & $6600-8600$ \\
\hline 59 & La Veiga & Playing-card & $505 \times 316$ & 15.73 (est) & 1542 (est) & 1.68 & Cropmark & 1 & $\begin{array}{l}1 \text { (int. } \\
\text { clauicula) }\end{array}$ & $7650-10,000$ \\
\hline 60 & San Justo & Playing-card & $507 \times 311$ & 15.59 & 1574 & 1.40 & Cropmark & 1 & - & $7600-9900$ \\
\hline 61 & $\begin{array}{l}\text { Villamontán de la } \\
\text { Valduerna } 1\end{array}$ & Playing-card & $287 \times 205$ & 5.90 & 969 & 0.66 & Cropmark & 1 & 2 & $2900-3750$ \\
\hline 62 & $\begin{array}{l}\text { Villamontán de la } \\
\text { Valduerna } 2\end{array}$ & Playing-card & $243 \times 164$ & 3.92 & 790 & 0.61 & Cropmark & 1 & $\begin{array}{c}1 \\
\text { (Titulus) }\end{array}$ & $1900-2500$ \\
\hline 63 & $\begin{array}{l}\text { Villamontán de la } \\
\text { Valduerna } 3\end{array}$ & Playing-card & $77 \times 46$ & 0.34 & 229 & 0.46 & Cropmark & 1 & - & $150-200$ \\
\hline 64 & $\begin{array}{l}\text { Villamontán de la } \\
\text { Valduerna } 4\end{array}$ & Playing-card (?) & $408 \times 206(\mathrm{~min})$ & $9.4(\min )$ & $638(\mathrm{~min})$ & 0.74 & Cropmark & 1 & - & $4600-6000$ \\
\hline 65 & $\begin{array}{l}\text { Villamontán de la } \\
\text { Valduerna } 5\end{array}$ & Playing-card & $145 \times 142$ & 2.25 (est) & 577 (est) & 0.95 & Cropmark & 1 & - & $1100-1400$ \\
\hline 66 & $\begin{array}{l}\text { Huerga de } \\
\text { Garaballes }\end{array}$ & Irr. Playing-Card & $299 \times 185$ & 4.66 (est) & 489 (est) & 2.18 & Cropmark & 1 & - & $2250-2950$ \\
\hline
\end{tabular}


As we stated before, the majority of Roman military fortifications were temporary sites [59] [59,136]. The most prominent structures were the defences, which commonly were earth ramparts surrounded by one or more ditches. Military occupation can be also traced thanks to the recovery of other material remains, generally metallic objects [130]. Unlike other archaeological sites, pottery is not an element to be found in abundance in many cases, while organic elements -leather used for tents, textiles for clothing or wooden artefacts- are often not well preserved.

By detecting the ancient and ramparts we can easily recognise the general layout of these sites, as well as calculate both the size and the total length of the defensive perimeter. The playing-card shape has been recognised as one of the most characteristic features of the marching camps of late Republican and early Imperial times [57,59]. Nevertheless, these typological models were adapted where necessary. Previous archaeological analyses in the study area have revealed the degree of variability in marching camp layouts which are impacted by local topography [17,122]. This way, the deformation of those canonical squared and rectangular layouts was usual, from slightly variations to openly irregular shapes. In order to check if there is a direct relationship between these two factors, we calculated the mean slope of these sites by using a 5m LiDAR-derived DEM provided by the IGN.

Ancient writers stated that one of the most important rules when setting a camp was to provide enough space for tent pitching without compromising its defensibility by enlarging the ramparts excessively (Ps.-Hyg. 56). The garrison occupying the fortification had to be strong enough to man it. The model escalated exponentially: the bigger the site, the larger the inner space to set tents for the troops. However, the defensive perimeter grew linearly using regular planimetric models. In short: the bigger the site, the easier to defend it.

Several scholars have discussed about the best way to calculate the occupation of these sites, making use of diverse historical and archaeological sources [120,137-139]. This debate exceeds the goals of this paper, so suffice to say that we have obtained an estimated manpower value for these sites by using the most suitable models in any case, chronologically and typologically speaking. As we have already discussed elsewhere [6], this variable might be also important to define the functionality of these enclosures. A legion-like unit would have a different impact in the landscape than a small detachment. Due to logistic and strategic reasons, the presence of the former tended to be shorter in time than that of the latter. Finally, we assessed the state of conservation of the defences to determine whether they are visible on the ground or if the only way to document them is remotely. Although the existence of a rampart/earthwork is assumed [57], it seems to have been razed to the ground in the majority of cases. Only occasionally its trace is recognisable as cropmark or soilmark. Since the presence of multi-ditched camps is not frequent in northwestern Iberia [122], we also recorded this variable regarding the enclosures' defences. Last but not least, we collected information regarding the presence of entrances and the existence of defensive features guarding them. The claviculae-curving length of rampart-and the titulus (or titulum) — short, advanced rampart-are two of the most common solutions in a Roman camp $[123,140,141]$, but other interesting features are reported here.

\subsection{Northern Castile (Burgos and Palencia Provinces)}

Since 2007, our research has explored the articulation of the archaeological landscapes in the Odra-Pisuerga watershed (Burgos-Palencia) between the Late Iron Age and Late Roman periods (ca. 5th c. BC to 4th c. AD) [142]. More recently, the project has focused on the study of the territory of the modern-day town of Sasamón (Burgos), where an indigenous oppidum-large hillfort-(Cerro Castarreño), a Roman town (Segisamo), and various Roman camps can be found [43].

However, the evidence related to the Roman army's presence around Sasamón was disconnected from other important clusters of military activity located some kilometres northwards. That is the case of the legionary base at Pisoraca (Herrera de Pisuerga), which was occupied between late 1st c. BC and mid-1st c. AD [143], or the series of camps related to the Augustan campaigns against the Cantabri (26-19 a. C.) located elsewhere in the southern foothills of the Cantabrian Mountains [7,17,40,144,145]. Being aware of the strategic thinking and logistical needs of the Roman army [59], the starting point 
for this research was to explore the possible existence of missing links that could help us understand the military deployment better. In accordance with the Heritage Laws, all the relevant territorial administrations have been informed of the discovery of the following archaeological sites: Servicio Territorial de Cultura y Turismo de Palencia (Reg. 200110249757, on 25/06/2020, with one brief addition: 200117149072 -16/10/2020-); Servicio Territorial de Cultura y Turismo de Burgos (Reg. 200111007638, 5/07/2020); and Dirección General de Cultura de Cantabria (Reg. REGAGE20ee00002540244, 30/06/2020).

\subsubsection{Odra-Pisuerga Region (Burgos)}

Three new sites were incorporated into the ensemble of Roman military sites in this area. Two of them were documented northwest of the village of Sotresgudo, one located at Tortolondro and the other at Matimocha (Figure $6(1,2)$ ). The former was first discovered by Alfonso Bourgon de Izarra and is presently under study by Ignacio Ruiz Vélez. The available data allows us to classify it as a multi-enclosure camp, a recurrent phenomenon in the Cantabrian Mountains [39,146]. The UAV-derived orthophotography allowed us almost to complete its northern outline (Figure 7A), revealing the existence of a slightly irregular playing-card shaped camp exceeding 20 ha and protected by a double ditch (fossa duplex) in some areas. The integration of a small but prominent hilltop (917 masl) within the perimeter of the camp is equally noteworthy.

The camp of Matimocha is another example of the morphological diversity and layout irregularity adapted to local topography in northwestern Iberia [122]. This phenomena usually dated back to the late Republican and early Imperial periods [120]. The site takes advantage of the defensive position provided by the small plateau located between the Tovares and Olmillos streams (900 masl). Adapted to the local topography to avoid depressions, it draws a curved, sinuous outline in the process. Far from being unique, this morphological solution and settlement pattern had been documented at El Alambre (Fuencaliente de Lucio, Burgos), a Roman camp located only $15 \mathrm{~km}$ to the north [38]. Matimocha is, however, slightly bigger (13.3 ha).
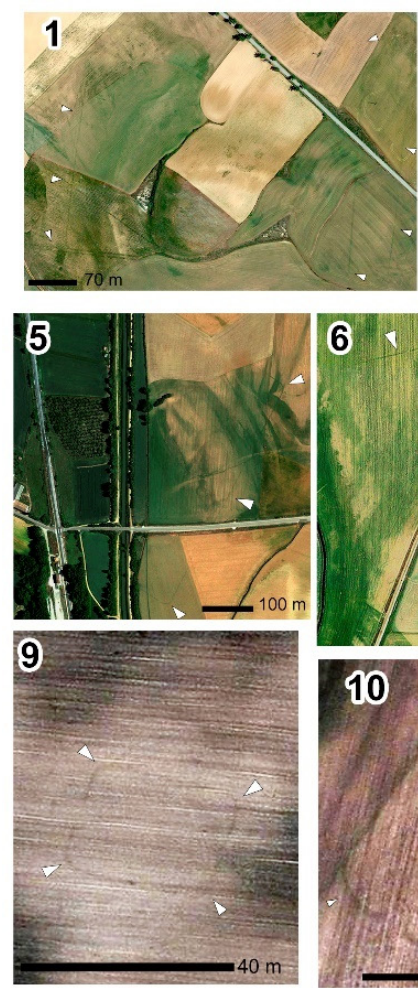
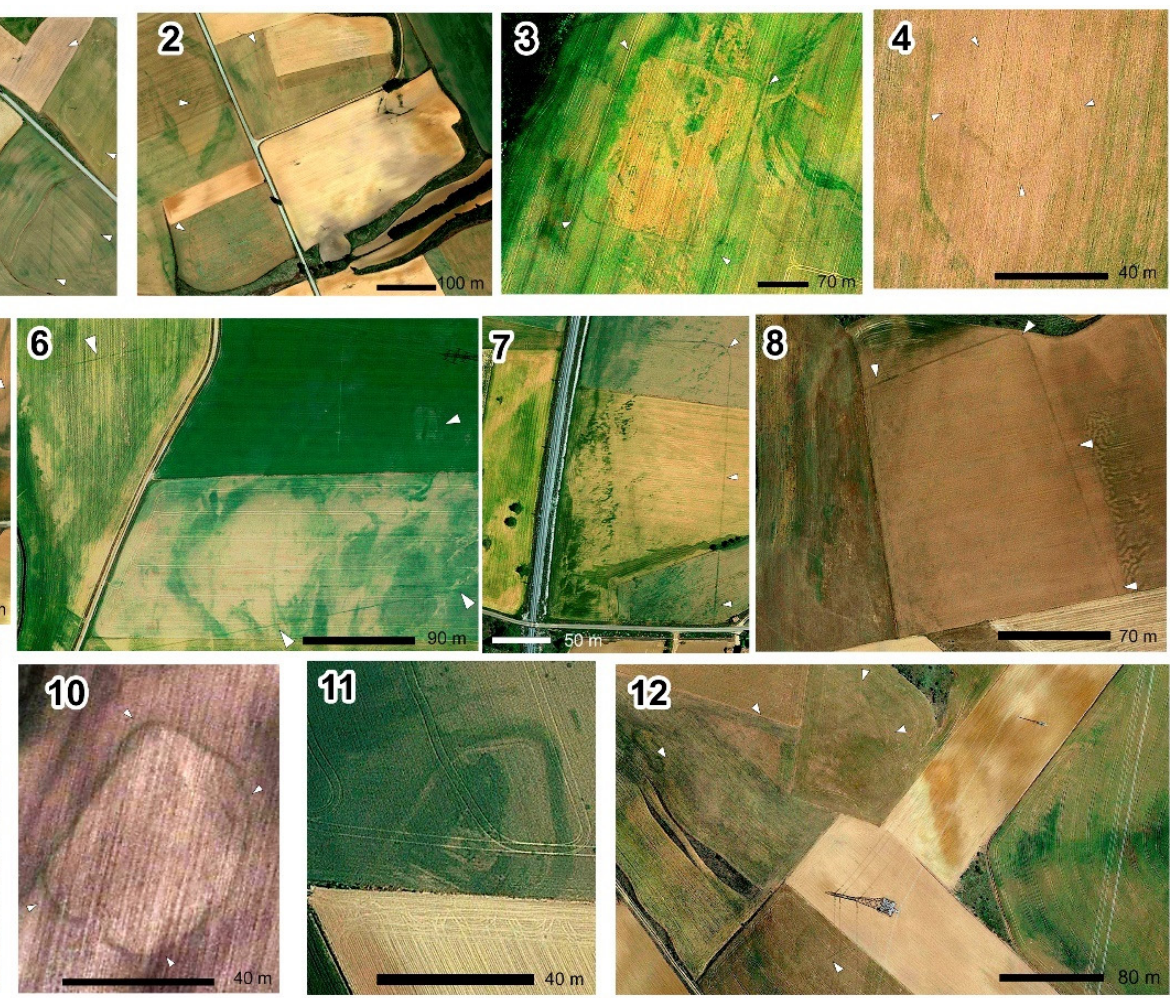

Figure 6. Archaeological features in northern Castile-southern Cantabria as seen on the satellite imagery provided by Google Earth. The numbering follows their order of appearance in the text, also summarised in Table 2. 

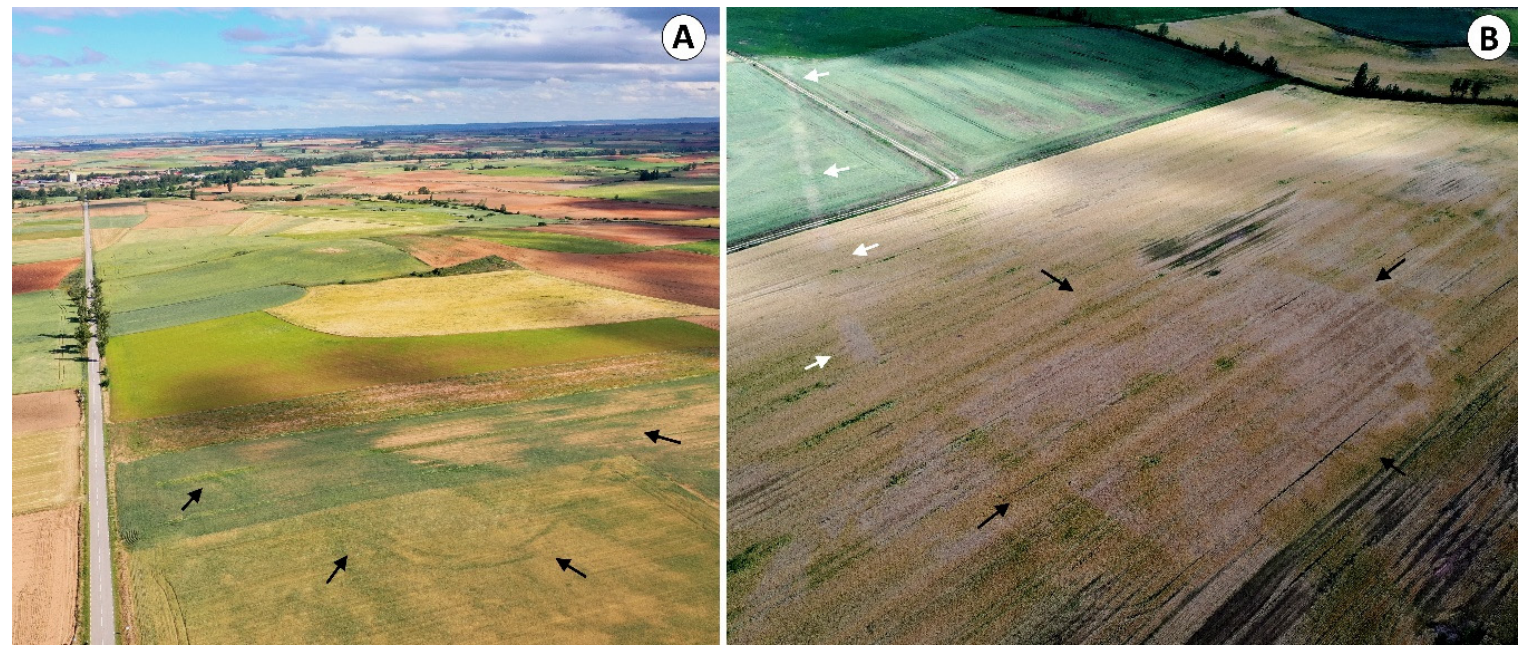

Figure 7. Aerial photographs of the camp of Tortolondro (black) (A), the Roman road (white) and the camp (black) at Quintanilla de Riofresno (B).

The Riofresno and Las Huelgas streams-tributaries of the River Pisuerga-converge approximately $2 \mathrm{~km}$ to the south of the village of Quintanilla de Riofresno (Figure 6(3), Figures 7B and 8A) (municipality of Sotresgudo). A small, playing-card shaped camp (0.94 ha) was established on a hilltop located here (830 masl). Not surprisingly, the morphology of this little plateau forces the orientation of the fortification and conditions its defensive system, to the point where no defensive modifications were made to the western side. The slope makes it unnecessary at this point. Quite interestingly, the camp also controls a significant section of the Roman road between Segisamo and Pisoraca [147], hence the place name La Calzada (the road).
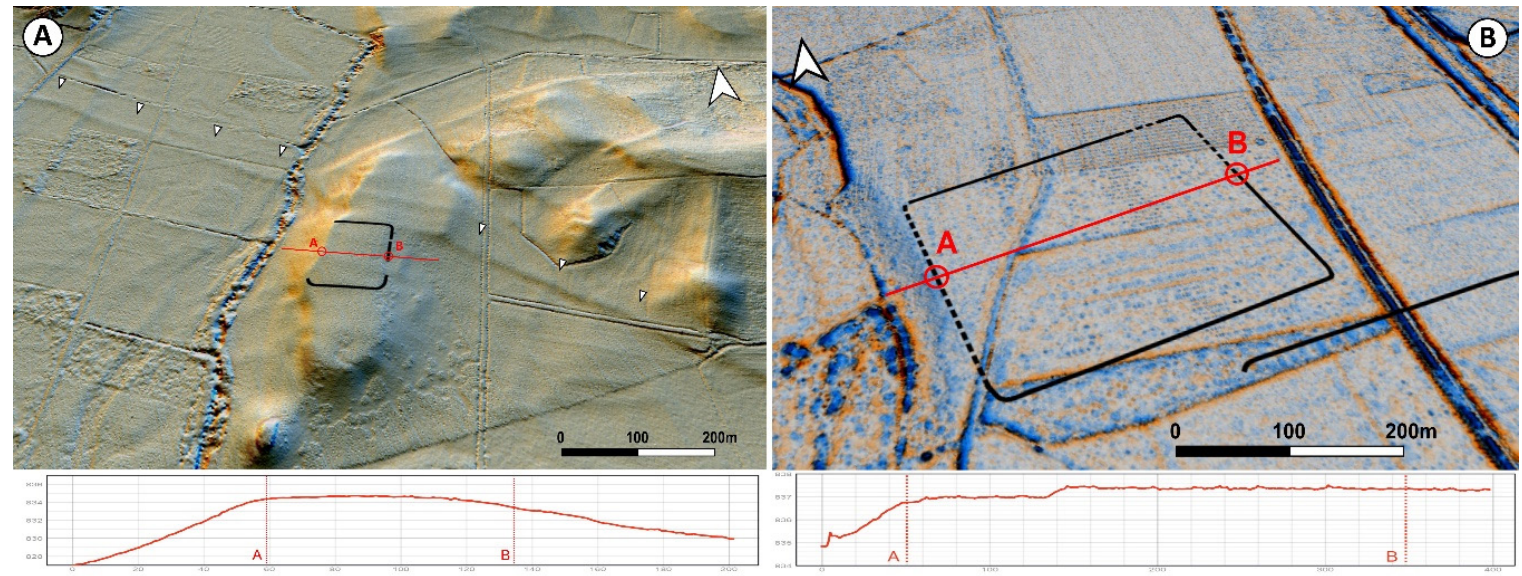

Figure 8. La Calzada (A) and Herrera 3 (B) enclosures. Location and traverse terrain profile. Note the presence of the Roman road in the first case (white arrows). Oblique 2.5D view from the $1 \mathrm{~m}$ LiDAR-DTM using the PNOA data. Visualisation techniques: SAGA GIS resampling filter (A) and multi-directional hillshade RVT (ZRC SAZU).

The last site is located at the southern end of the study area, not far from Melgar de Fernamental and about $600 \mathrm{~m}$ to the east of the River Pisuerga. This small, square enclosure ( $820 \mathrm{sq} \mathrm{m}$ ) was built on flat terrain-San Andrés, 791 masl-today is dedicated to cereal farming (Figure 6(4)). Given the similarities with other small enclosures described in this paper, we assume that it could be a Roman fortlet $[80,148]$. The Roman road De Italia in Hispanias (From Italy to Spain) crosses the Pisuerga not far from here [149]. 


\subsubsection{Boedo-Ojeda Region (Palencia)}

Urban archaeology revealed that the modern-day town of Herrera de Pisuerga was built on top of several permanent Roman military sites [143,150-152]. Evidence sustains that Pisoraca was the operational base of the legio IIII Macedonica (ca. 19 BC-39/43 AD), the ala I Parthorum and the cohors I Gallica (mid-1st-early 2nd c. AD) during their stay in Hispania. Aerial archaeology had identified the existence of a large marching camp in the area of La Virgen/Las Huelgas [19], henceforth Herrera 1 (Figure 6(5)). Our survey adds four new sites to this account, all of them placed on the eastern bank of the River Pisuerga.

Satellite imagery led to the discovery of two playing-card shaped camps approximately $1.3 \mathrm{~km}$ northeast of the town of Herrera de Pisuerga, in a meadow area on the eastern bank of the River Pisuerga. At Camino Hondo (834 masl) two linear sections and two rounded corners form an inverted $\mathrm{L}$, revealing the former existence of an enclosure (Herrera 2) (Figure 6(6)). Even if it is not possible to reconstruct the defensive perimeter in its entirety, the camp exceeded 11 ha and followed a south-north alignment. Another site (Herrera 3) is located only $40 \mathrm{~km}$ to the north of the former, at a place named Barrialba (Figure 6(7)). Although its western defensive line is not recognisable, we can infer its position thanks to the location and development of one of the rounded corners as well as the particular morphology of the terrain (a gentle step) (Figure 8B). This way, it is possible to discern a mid-sized, playing-card shaped camp (ca. 7 ha) following an east-west axis.

Herrera 4 was identified over a soft hill (870 masl) $1.8 \mathrm{~km}$ to the east of Herrera de Pisuerga, immediately to the south of the Valdehorno Stream (Figure 6(8)). This settlement pattern not only seeks to reinforce the defences of the camp but also to control an extensive section of the valley of the River Pisuerga. Once again, the defensive perimeter cannot be recognised entirely, but its playing-card layout is clear. Besides, the morphology of the hill allows us to limit its extension to c. 3 ha. The internal clavicula-type entrance detected on its northwestern side could be indicative of its orientation.

Several structures were documented less than $2 \mathrm{~km}$ to the southwest of Herrera (Figure 9). The PNOA-RGB 2007 coverage allowed the detection of some straight lines and curved angles, but the determination of individual enclosures is not an easy task due to their proximity and the presence of recent, underground structures, such as drainage pipes. It is possible to identify two fortlets to the south, controlling Las Pardas valley. Las Pardas 1 is a small, playing-card shaped enclosure located on a hilltop (860 masl) to the north of this area (Figure 6(9)). The presence of a titulus guarding the western side reinforces its characterisation as a Roman military site. Las Pardas 2 shows an almost identical settlement pattern ( 855 masl) to the south of this area. While three of its sides form a playing-card, shaped enclosure, the last one adapts to the local relief describing a curved trace (Figure 6(10)). An indication of an entrance is recognised in its southernmost side.

One last feature was documented $2.5 \mathrm{~km}$ to the south of Herrera de Pisuerga, at the confluence of the River Pisuerga and the Valdemiranda Stream (820 masl) (Figure 6(11)). Archaeological remains dating from Roman times have been recovered in the area for decades [153]. Pentagonal in shape, its eastern half resembles the familiar playing-card layout, while the western one projects pointedly towards the river basin. The cropmarks allow us to differentiate between an external, darker outline and an internal, lighter enclosure. They presumably correspond with a ditch and an earthwork. The interior shows traces of what could be archaeological structures. Given its small size, we hypothesise that those are the remains of a fortlet similar to others identified in northwestern Iberia [6].

Besides the evidence gathered around Herrera de Pisuerga, only the two Roman camps of Los Majuelos and Los Ávilas were known in the remaining Boedo-Ojeda region to date [40]. They are part of an undergoing archaeological project "Cántabros y Astures frente a Roma en Castilla y León", supervised by Esperanza Martín Hernández and funded by the Castile and León autonomous government. Our survey documented up to nine possible Roman military sites. All of these enclosures were located on the banks of the River Pisuerga tributaries, revealing a similar settlement and mobility pattern (Figure 2). 


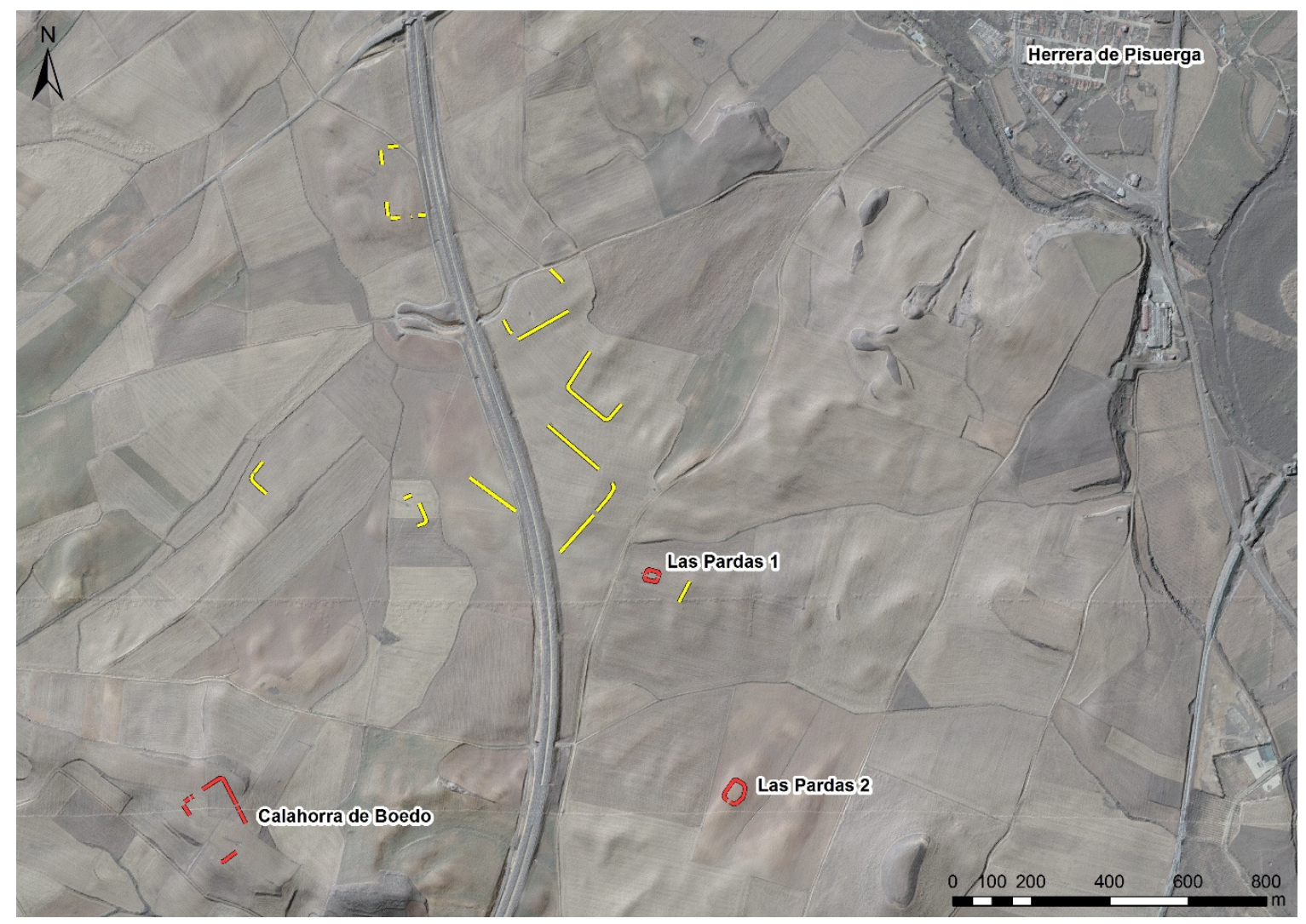

Figure 9. Enclosures (red) and possible features (yellow) detected to the southwest of Herrera de Pisuerga. Hillshade visualisation from 1m LiDAR-DTM using the PNOA data.

At Calahorra de Boedo, just $2.6 \mathrm{~km}$ to the southwest of Herrera de Pisuerga, another enclosure was discovered on a hilltop (911 masl) between the Boedo and Pisuerga valleys (Figure 6(12)). This small trapezoidal enclosure with rounded corners has a great vista across the surrounding landscape. Westward, a set of three was identified at La Vega, a plain situated on the southern bank of the River Boedo (870 masl), close to the modern-day village of Páramo de Boedo. The most recognisable feature (Páramo de Boedo 1) is a 3.6 ha playing-card shaped enclosure whose eastern side is now partially lost to a path (Figure 10(13)). Immediately to the south of this camp, a dark linear trace follows a WNW-ESE direction for $200 \mathrm{~m}$. A second linear feature is visible $130 \mathrm{~m}$ to the west of the former, developing a rounded corner at its northern end (Figure 10(14)). We have interpreted these two alignments as part of a bigger enclosure (Páramo de Boedo 2, at least 5.2 ha) whose layout is not completely clear, but maybe it was a variation of the playing-card plan. Archaeological evidence is even scarcer when it comes to the last feature identified at La Vega: just two linear cropmarks united by a rounded corner (Páramo de Boedo 3) (Figure 10(15)).

A similar anomaly is attested in the surroundings of La Vid de Ojeda. Satellite imagery allowed us to document three playing-card shaped enclosures on both banks of the River Burejo (865-875 masl). Once again, their degree of preservation is uneven, with several sections of their defensive perimeter now lost to ploughing or infrastructure building. The outline of the first site (La Vid 1) is 70\% complete (Figure 10(16)), revealing the former existence of a medium-sized camp (4.37 ha) in the open area to the east of the village (named Santa María, Los Pontones or Calzada). Its major axis follows an E-W orientation, and its western side shows an internal clavicula.

Another feature (La Vid 2) is recognisable to the north, at Fresnillo, already on the eastern bank of the river (Figure 10(17)). Unfortunately, our data only allows documenting a rounded corner and two short linear sections of this enclosure, making it difficult to estimate the actual shape and size of this site. The situation is slightly better at Los Yazgos, where the River Burejo and the Valgrande 
Stream converge. Two linear, parallel cropmarks -one of them also drawing a rounded corner-delimit a small-sized (at least 3.43 ha), playing-card shaped enclosure (La Vid 3, Figure 10(18)). Similarly to La Vid 2, the camp orientation follows a NW-SE axis.
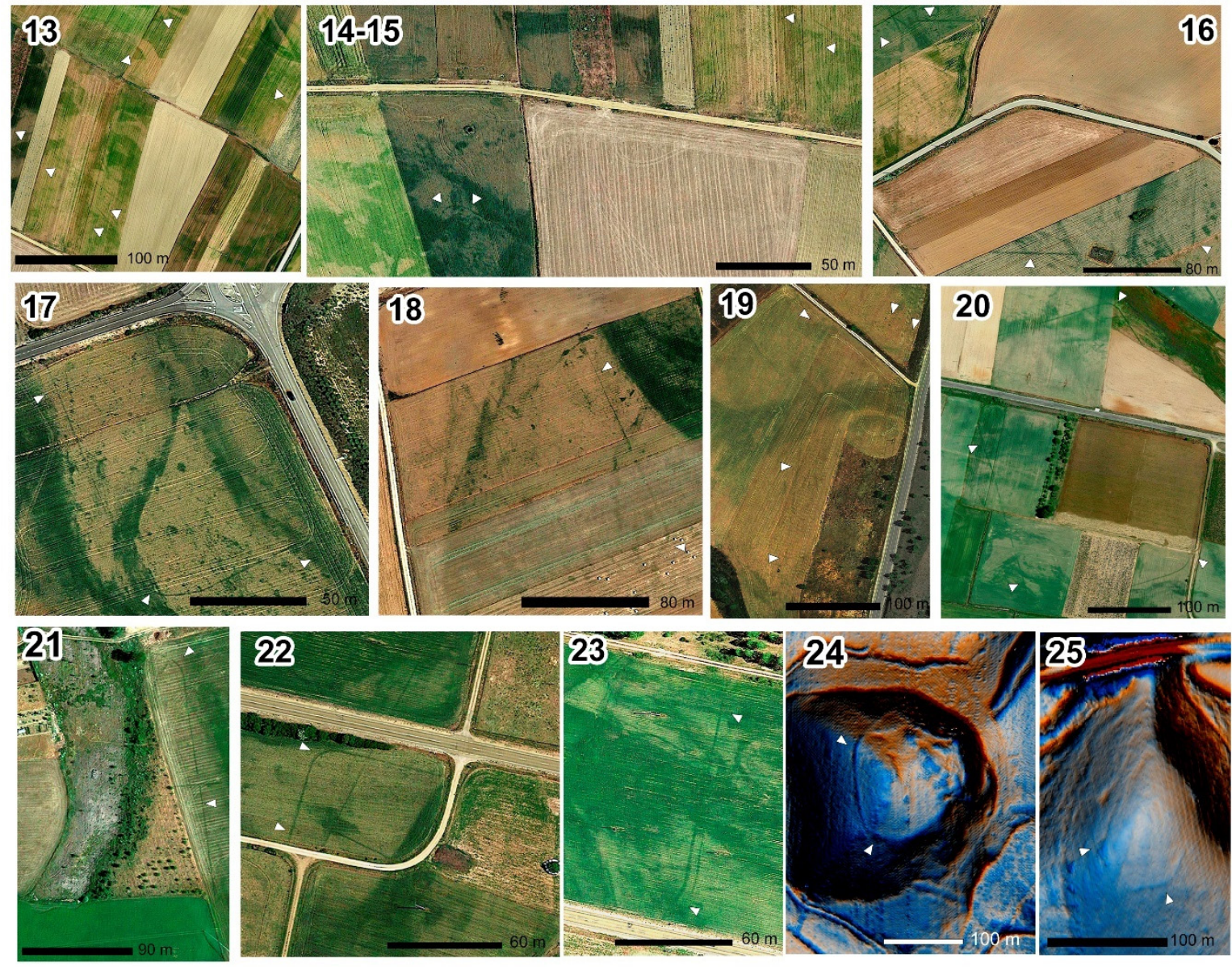

Figure 10. Archaeological features in northern Castile and southern Cantabria as seen on the satellite imagery provided by Google Earth and $1 \mathrm{~m}$ LiDAR-DTM using the PNOA data (visualisation techniques: SAGA GIS resampling filter). The numbering follows their order of appearance in the text, also summarised in Table 2.

The enclosure of La Charcona (Alar del Rey), is located about $6 \mathrm{~km}$ to the north of Herrera de Pisuerga, on a plain area controlling the interfluve of the River Pisuerga and Fuente de Palacio Stream (865 masl). This is a small-sized camp ( $\mathrm{min} .2 .5 \mathrm{ha}$ ) whose main axis runs in an N-S direction (Figure 10(19)). The traces of two rounded corners and three sides are still recognisable, as well as a titulus guarding its northern entrance.

The last camp is located $800 \mathrm{~m}$ to the east of the modern-day village of Micieces de Ojeda, at the confluence of the River Villavega (a tributary of the River Burejo) and the Parijuelo Stream (930 masl) (Figure 10(20)). According to the cadastre, different areas of this meadow are named La Fuentecilla, La Cuenca or Lomillano. Although the presence of a road and recent land consolidation works have contributed to the deterioration of this marching camp, its defensive perimeter is still recognisable from the air. Except for the northeastern side, which is significantly projected towards the exterior, it tends to draw a playing-card layout. The southwestern wall also shows a clavicula-type entrance. Other traces of dubious interpretation are visible in its surroundings of this mid-sized fortification (7.43 ha). 


\subsubsection{Montaña Palentina Region (Palencia)}

The survey of the upper course of the River Pisuerga lead to new archaeological data in an area previously explored by several archaeologists $[7,144]$. The remnants of a marching camp are still visible at La Capilla (876 masl), $90 \mathrm{~m}$ to the east of Santa María de Mave (municipality of Aguilar de Campoo) (Figure 10(21)). The presence of a $400 \mathrm{~m}$-long alignment ending in rounded corners indicates that the enclosure presumably developed westwards, now lying under the modern-day village, and taking advantage of the gentle slope towards the River Pisuerga. Although the exact morphology and full extent of this camp are unknown, evidence supports the former existence of a vast playing-card shaped enclosure.

At the moment, Javier Quintana is carrying out an archaeological project in the area (Personal communication from Javier Quintana (Junta de Castilla y León), on 01/09/2020). This research has revealed the traces of a large Roman vicus -small town- related to the oppidum of Monte Cildá. Although there are no signs of Roman military activity in the area currently under archaeological excavation, we cannot forget about the ephemeral archaeological record Roman camps usually left behind [57] and the strategic location of a temporary camp in the route towards the mountains is undeniable.

Another argument could be used against the characterisation of the traces mentioned above as part of a Roman camp. The northern side of the enclosure is located on a wetland plain that used to be a meandering river. The PNOA 2009 NIR image shows clearly the palaeo-bed of the river, and this meander was possibly a development that took place after Roman times (Figure 11). Otherwise, neither the camp nor the vicus could have ever existed.

Some interesting, but fragmentary traces have been documented near Ligüérzana (municipality of Cervera de Pisuerga). The confluence of the River Pisuerga and the Gramedo Stream formed a small platform (968 masl), the only possible natural defence at the bottom of this valley. At Santibáñez, two linear features join to form a rounded corner, while some dim traces further east could also belong to this small enclosure (Figure 10(22)). At La Cañada (Figure 10(23)), two linear features run parallel from north to south, resembling a double ditch. One of them shows a rounded corner in its southern end.

The landscape becomes mountainous in the northernmost area of the province of Palencia. About $1 \mathrm{~km}$ to the east of Nestar (municipality of Aguilar de Campoo) a hill (966 masl) stands controlling the small valley of the Reilaja Stream. It is here that LiDAR visualisations and satellite imagery reveal the existence of a rampart surrounding the top of this elevation (Figure 10(24)). Even if its layout is irregular, there is a tendency to draw straight lines and rounded corners, following a morphological pattern already documented in several Roman castella -fortified outposts- in northwestern Iberia [122]. However, the characterisation of this small enclosure (1.23 ha) demands an in-depth archaeological exploration.

\subsubsection{Valdeolea Region (Southern Cantabria)}

A similar anomaly to that seen in Nestar occurs at Ventas, $800 \mathrm{~m}$ to the northeast of the village of Matarrepudio (municipality of Valdeolea). A trapezoidal rampart delimits the top of a hill (981 masl), controlling the course of the Henares Stream (Figure 10(25)). From here is also a wide visibility over the main pass of the Cantabrian mountain range. Through the nearby mountain pass of El Pozazal it is possible to access the region of Campoo and, from there, the Atlantic coast of modern-day Cantabria. The small castella are not a rare feature in the vicinity [154,155], but once again, further research is needed. 


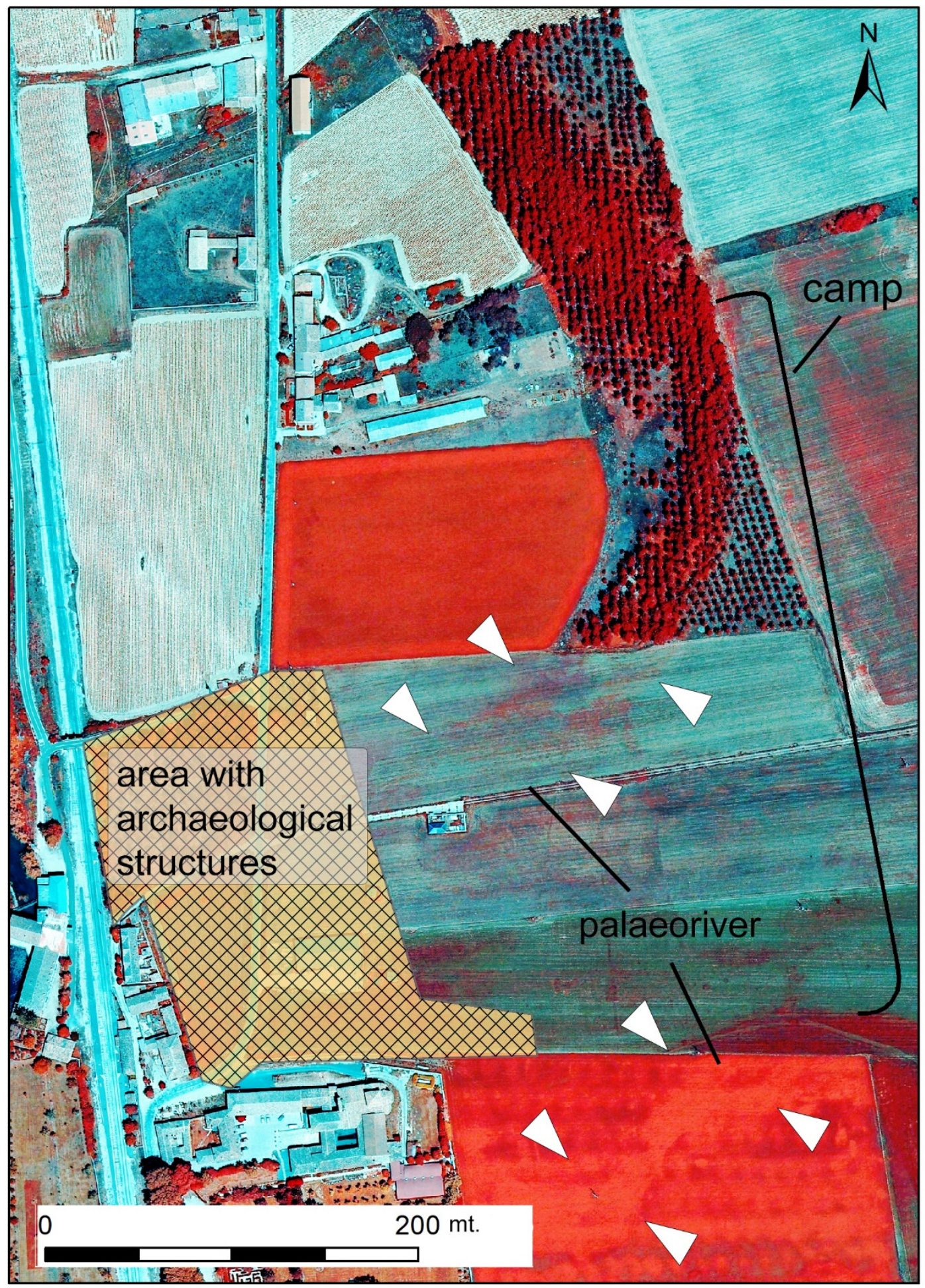

Figure 11. River Pisuerga meander/palaeochannel at La Capilla (Santa María de Mave) as seen on PNOA-NIR coverage. The camp and the archaeological structures, predating the formation of meander, are highlighted.

\subsection{Leonese Region}

The experience acquired in Palencia and Burgos contributed to define new research areas in the province of León (Figure 3). The lack of previous research in these territories had generated regional distribution maps in archaeological literature regarding the Roman military presence that 
a renewed methodological approach might transform [17]. As it happened in our first study area, the Leonese territory shows upland areas to the north and west and extensive sedimentary plains in its southeast quarter. Connecting these two different landscapes, we can find an area formed by open valleys separated from each other by low elevations, often plateaus, similar to those located in northern Palencia.

From an archaeological perspective this is a poorly understood area, despite being the place where some of the first Roman camps were identified in northwestern Iberia [69,70]. In this paper, we present the results of our survey in the central area of the province of León, distributed among the middle sections of the Bernesga, Órbigo and Tuerto river basins. In accordance with the Heritage Laws, the Servicio Territorial de Cultura y Turismo de León has been informed of these discoveries (Reg. 200110251132, on 25/06/2020, with one brief addition, Villamontán 5, Reg. 202090000001634, on 3/10/2020). On 31/07/2020 the Autonomous Government of Castile and León positively answered to our formal request (28/06/2020) for the development of a scientific project focused on the characterisation and cataloguing of the archaeological evidence related to the Roman army in the province of León (Exp. 20/211-LE). Once again, we documented several enclosures in fertile plains, revealing the preferential use of valley bottoms for transit by the Roman army.

\subsubsection{River Bernesga Basin-Surroundings of León}

It seemed unlikely that no enclosures existed in the area surrounding the legionary fortress of León [156-158]. The use of remote sensing technologies has contributed to filling this void because we were able to locate two important clusters totalling 27 camps, as well as three other isolated sites. Other military-related remains may have existed around this city, completely disappearing in the last decades. The surroundings of León have witnessed a major transformation due to urban and industrial developments. In fact, many of the enclosures revealed by our survey show only partial traces of their perimeters, often being affected by recent landscape transformations.

\section{Villaquilambre Cluster}

A cluster of at least nine enclosures was identified in Villaquilambre, a village $4 \mathrm{~km}$ to the NNE of the city of León (Figure 12). All of them are located on two wide, flat terraces to the west of the River Torío, some $10 \mathrm{~m}$ above the watercourse (840-860 masl). Different aerial and satellite coverages were used to this end.

Villaquilambre 1 is situated on the highest terrace, SW of the complex. Two rounded corners and the remains of three alignments form a possible playing-card layout. Further to the SE, on the lower terrace, there are several discontinuous traces and two well-preserved rounded corners, which we interpret as part of a possible medium-sized enclosure, Villaquilambre 2.

On the same terrace, $80 \mathrm{~m}$ further north, three overlapping enclosures (Villaquilambre 3, 4 and 5) are visible. The first two are rectangular camps under 3 ha whose orientation is dissimilar. Villaquilambre 5 is an even smaller enclosure since its perimeter delimits a space of less than 1 ha. This overlapping behaviour replicates at Villaquilambre 6 and 7 (Figure 13(31)), as well as Villaquilambre 8 and 9, which are respectively located 300 and $380 \mathrm{~m}$ to the north.

According to surface area and morphology, we can identify two types of enclosures within this complex. First, there are small to medium-sized sites, with areas between approximately 1.7 and 5 ha showing a playing-card layout; these are the predominant type (e.g., Villaquilambre 2, 3, 4, 6 and 9). In addition, there are even smaller sites with less than 1 ha whose layout is squared or slightly rectangular but have rounded corners (e.g., Villaquilambre 5, 7 and 8). The case of Villaquilambre 1 is a particular one since only the eastern half of its perimeter has been preserved. However, we believe that it could belong to the first group stated above.

The degree of visibility and conservation of these sites is uneven. The diachronic use of different historic aerial coverages allowed us to document the progressive anthropogenic pressure in this 
periurban area, with the recent loss of some remains. For instance, we documented the partial destruction of Villaquilambre 1 between 2008 and 2010 and that of Villaquilambre 2 since the 1970s.

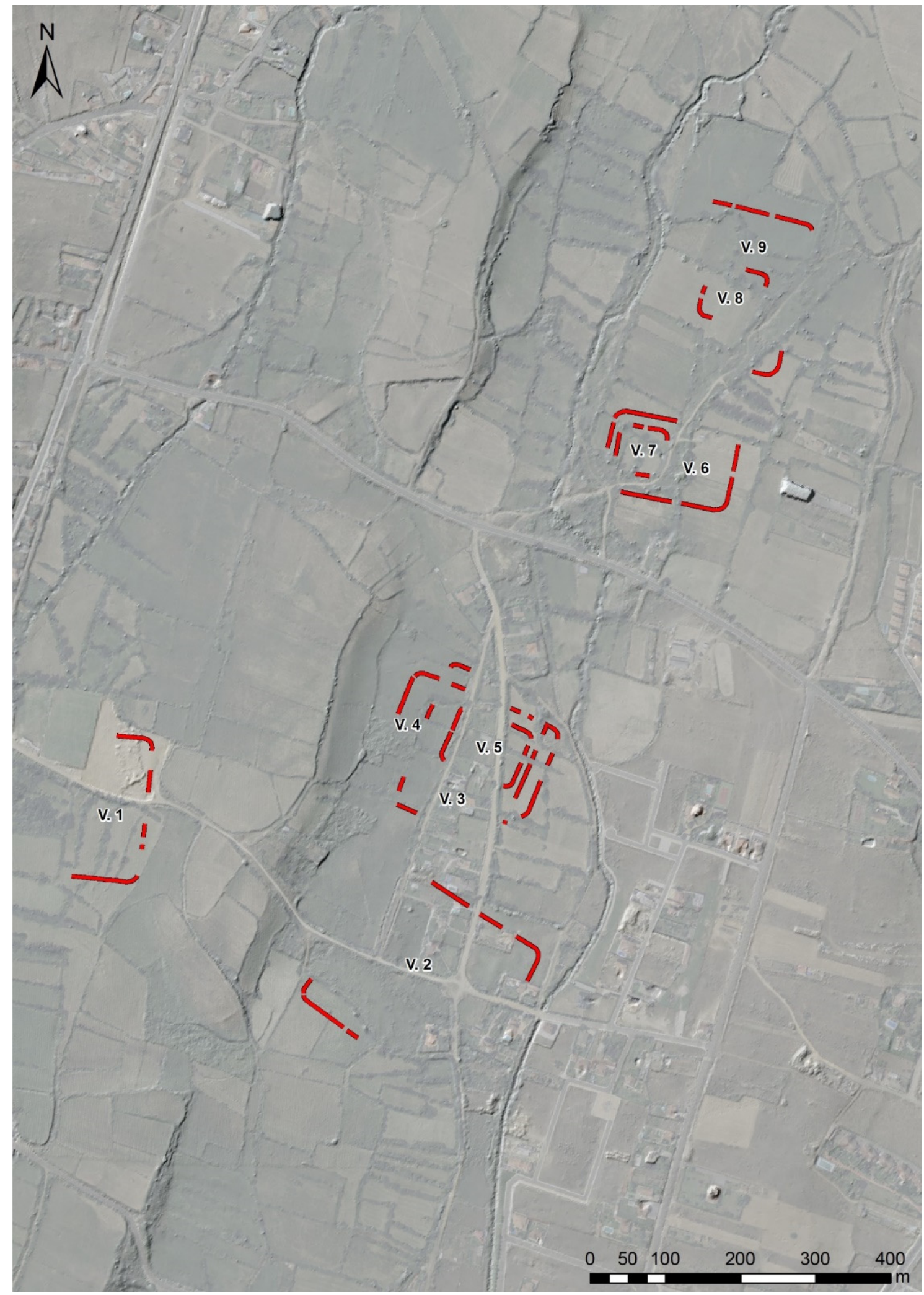

Figure 12. Enclosures (red) detected in Villaquilambre. Hillshade visualisation of the $1 \mathrm{~m}$ LiDAR-DTM using the PNOA data. 

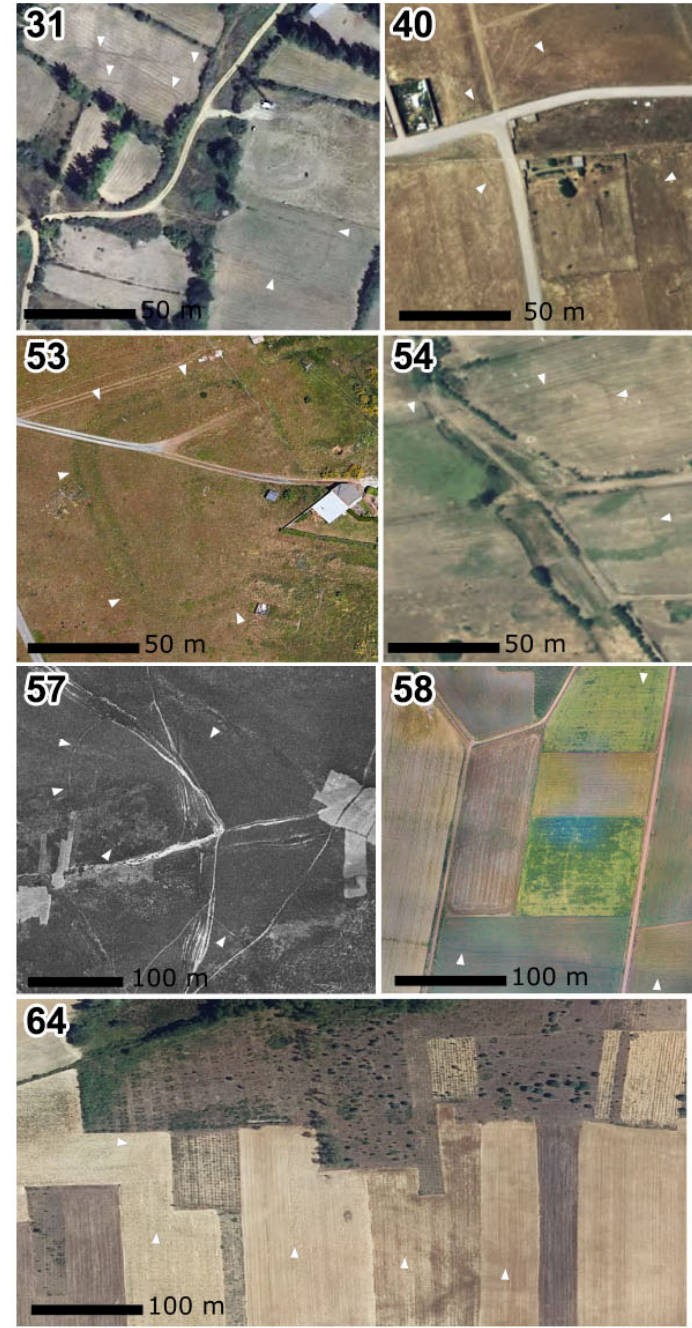
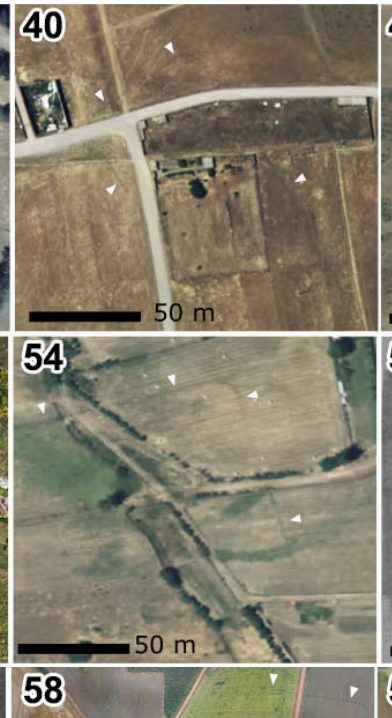
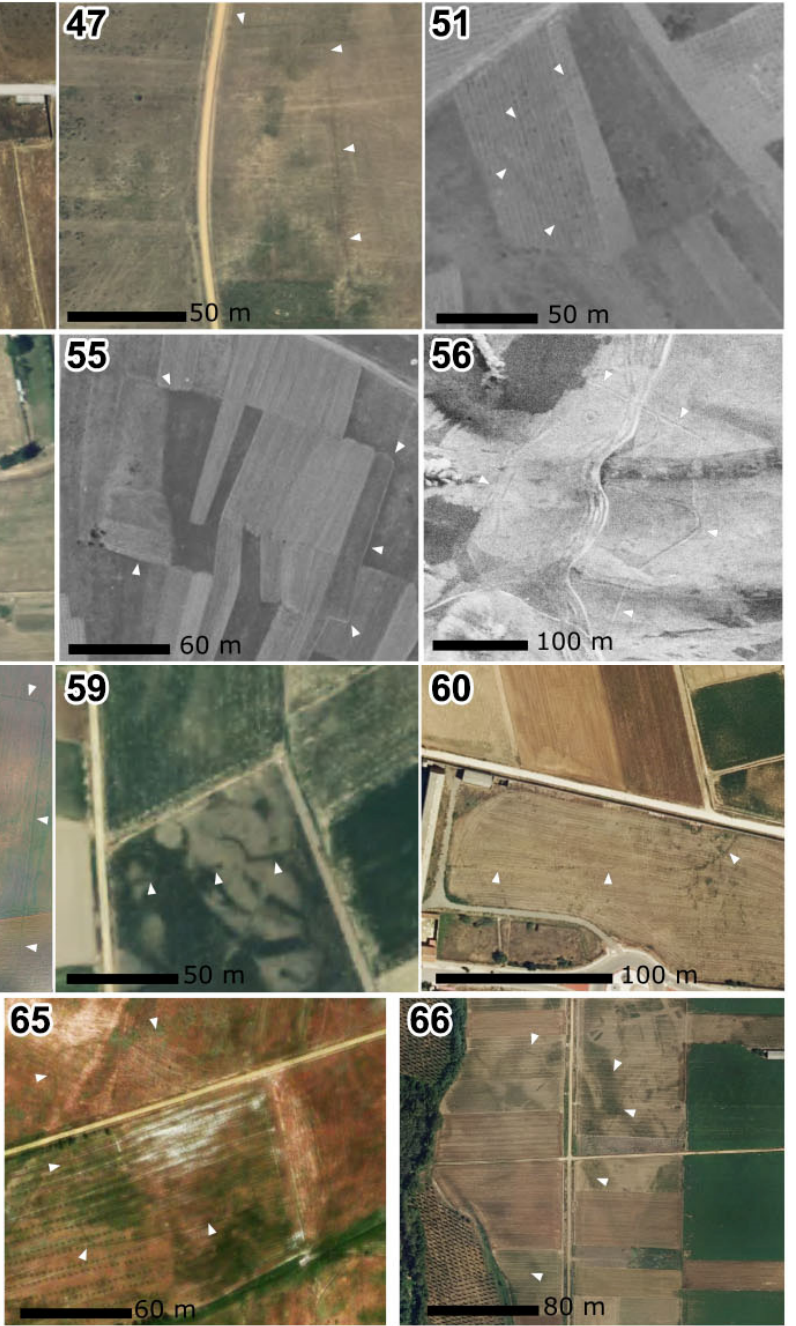

Figure 13. A selection of the archaeological features documented in the Leonese area as seen on the satellite imagery provided by Google Earth and Bing, the PNOA and historical aerial coverages.

The numbering follows their order of appearance in the text, also summarised in Table 3.

Oteruelo, Trobajo and San Andrés Cluster

We documented another concentration of camps $4 \mathrm{~km}$ to the west of León following the Roman road to Astorga and next to another possible ancient route heading north $[159,160]$. They were built on a plateau elevated about $20 \mathrm{~m}$ above the River Bernesga (860-890 masl). Administratively speaking, the sites lay between the towns of Oteruelo de la Valdoncina, Trobajo del Camino and San Andrés del Rabanedo.

We have been able to identify up to 18 sites with a different degree of preservation and visibility (Figure 14). The greatest concentration of structures was documented in the Trobajo area located to the south of the modern-day N-120 road. The development of an industrial estate during the last decades has surely destroyed other archaeological features we are not aware of. Unfortunately, aerial photography coverage previous to these developments does not have enough spatial resolution to offer complete documentation of this area.

From south to north, we identified at least twelve sites near the village of Trobajo del Camino and two more in San Andrés (municipality of San Andrés del Rabanedo) (Figure 13(40,47)). These are not the only ancient traces documented in the area, since there are other linear structures visible through remote sensing, although those do not show morphologies that are clearly recognizable as Roman military structures. However, the overall articulation and 
interpretation of those alignments remain problematic. After the notification of these findings to the provincial and regional Heritage management bodies and while writing this paper, the local press (Diario de León, on 17 July 2020, retrieved from: https:/www.diariodeleon.es/articulo/cultura/mayorcampamento-romano-leon/202007170132182030687.html, on 21 July 2020) reported the development of an archaeological project carried out by another research group to study these sites. Out of respect for our colleagues, we will not go into detail in the description or study of these enclosures pending their scientific, in-depth publication. Only two camps (Trobajo 1 and San Andrés 1) exceed 2 ha, while the rest of enclosures with recognisable areas are between 0.5 and $1.5 \mathrm{ha}$, showing quadrangular perimeters with rounded corners (Figure 15). No fortified accesses have been identified in any of them.

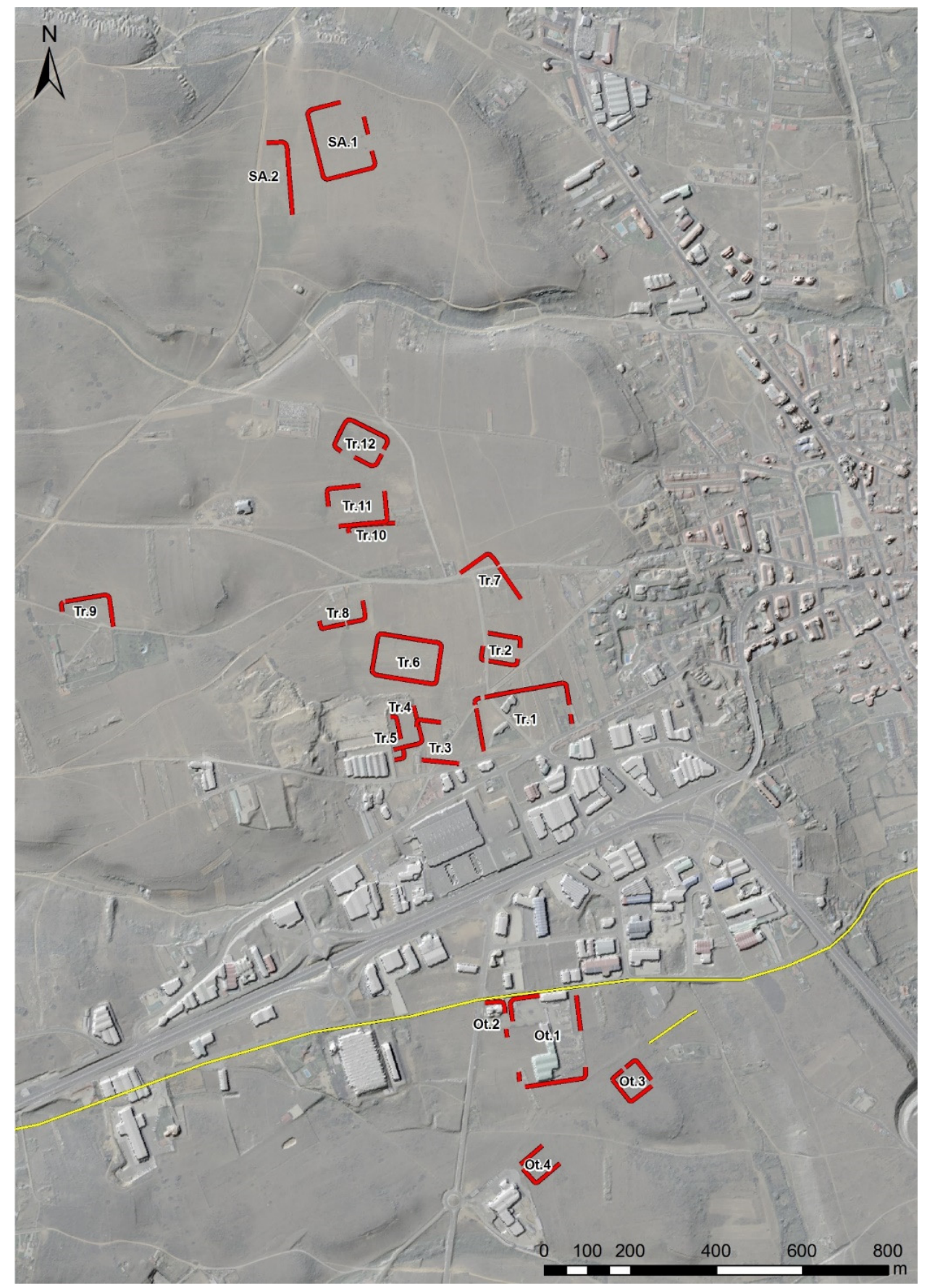

Figure 14. Enclosures (red) and possible roads (yellow) detected in Oteruelo, Trobajo and San Andrés. Hillshade visualisation of the $1 \mathrm{~m}$ LiDAR-DTM using the PNOA data. 


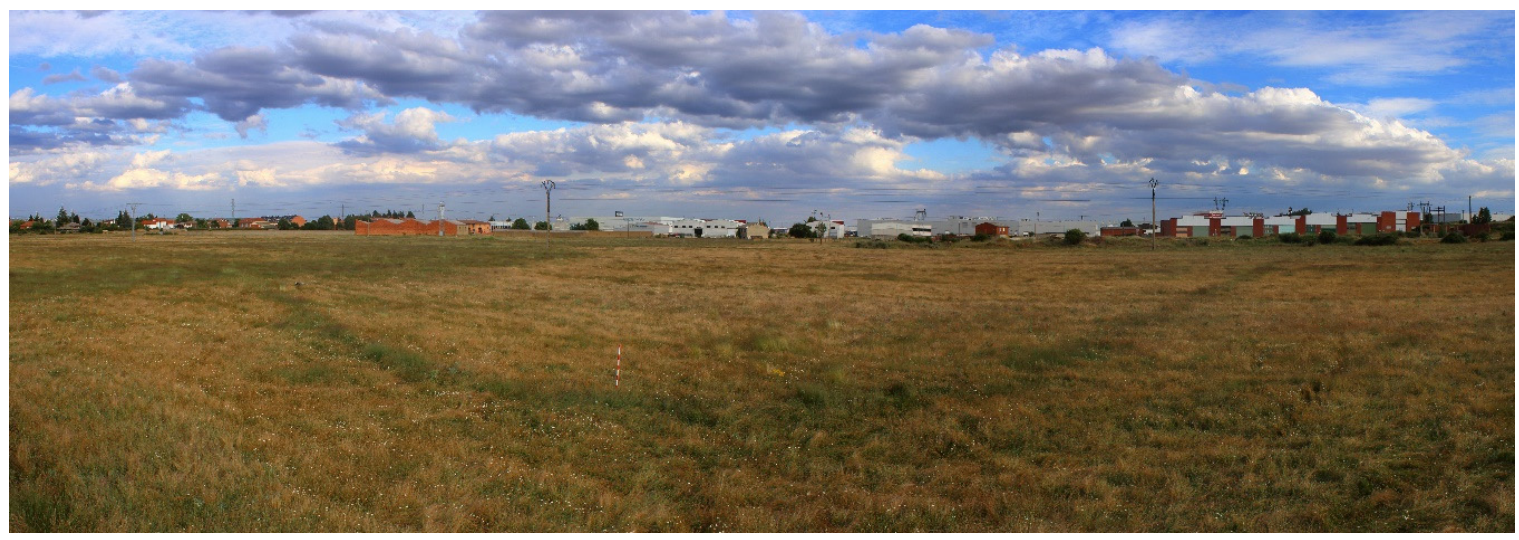

Figure 15. Round corner of the Trobajo 9 camp as seen in the field. The measuring rod (1 m) allows us to appreciate the size of the feature.

The four enclosures located near Oteruelo de la Valdoncina (municipality of León) constitute the southern end of this significant cluster, although they are separated from the other camps by the above-mentioned industrial state and the LE-20 highway. While the playing-card shaped layout of Oteruelo is recognisable, but today Oteruelo 2 is practically razed. However, the northern sides of both enclosures are parallel to the old road that connected León and Astorga. The colouring and differential growth of the vegetation allows us to identify Oteruelo 3 and 4 (Figure 13(51,52) and Figure 15). These smaller enclosures are also aligned with a traditional route connecting León and Fresno del Camino, to the southwest. The construction technique of this path resembles that of Roman roads in the region [161]: over an elevated platform, a transit surface was built using small stones.

\section{Oteruelo-Armunia Fortlet}

This site is located approximately $1.4 \mathrm{~km}$ to the SE from the previous group, on the border of two villages: Oteruelo de la Valdoncina and Armunia. Its location is adapted to the edge of the same plateau, controlling the Bernesga valley from its position ( 857 masl). The cropmarks here reveal the presence of a double ditch delimiting a small playing-card shaped enclosure (Figure 13(53)). However, modern land parcelling has affected its southeastern corner, while only one trench can be identified in the northwestern section of the site. Both its locational pattern and the significant effort invested in the construction of its defences suggest that the site was rather a fortlet subordinated to the military base of León than a temporary or practice camp linked to an army on the move.

\section{Sariegos}

Traces of another Roman military camp were documented next to the village of Sariegos, just $7 \mathrm{~km}$ to the NW of León. It is located on a flat meadow area (870 masl), on the western bank of the River Bernesga. Two rounded corners connect the discontinuous alignments forming its eastern, northern and western sides, revealing the former existence of a small-sized enclosure (min. 2.5 ha) (Figure 13(54)). Its location could answer to N-S movements along the valley or the Bernesga-Orbigo interfluve.

\section{San Miguel del Camino}

The River Órbigo follows a N-S direction, parallel to the River Bernesga in central León, forming a broad valley that connects the Northern Iberian Plateau and the Asturian Mountains [159,162]. An intense military presence has been attested in the latter mountainous area without a clear connection with the Roman military sites documented in the Leonese region $[19,21,22,36,163,164]$. Despite the importance of the Órbigo valley as mobility axis in N-S directions, only one Roman camp in Huerga de Frailes had been documented in the area so far [82]. 
The location of another site between the Bernesga and Órbigo river basins may help to plan future research in this practically uncharted zone. It is placed $1.3 \mathrm{~km}$ to the west of the village of San Miguel del Camino, on a flat area slightly elevated (933 masl) over some stream basins to the west (Figure 13(55)). The traditional land parcelling has fossilised the perimeter of this possible camp, which is also close to the road connecting León and Astorga [160]. Both aerial photography and the airborne LiDAR data allowed us to document its altered playing-card shaped layout. Unfortunately, there are no traces yet of other elements that could help to strengthen its Roman origin, such as fortified accesses.

\subsubsection{River Tuerto Basin-Surroundings of Astorga}

Astorga is an important town to understand the expansion of the Roman state in northwestern Iberia in early Imperial times. In fact, its foundation by military forces was attested a few decades ago, dating back to the last quarter of the 1st c. BC [165]. Despite the fact that some scholars have wondered if the Roman army may have occupied this location during the Cantabrian Wars, there is no strong evidence to support this. The city is located in the River Tuerto basin, a tributary of the River Órbigo. This constitutes a central geographical position in relation to the transit between the Duero and Sil basins. However, our knowledge about its broader geographical connection with Roman military movements is still uncertain. Until now, some military sites had been detected pinpointing E-W routes across the Leonese-Galician mountains, and therefore towards the Galician Atlantic coast [23,25,26]. Nevertheless, those sites are quite far away, having no clear connection with the eight new sites we recently documented. These sites in the Tuerto valley are less than two days march from Astorga. The eight new sites, described below from north to south, provide some of the first evidence of Roman military occupations in the area. Previously, other Roman military sites were already discovered and briefly described in Villamontán de la Valduerna, to the south of Astorga [166].

\section{La Silva}

The mountainous area surrounding La Silva village divides the headwaters of the River Tuerto from the basin of the River Sil. Two important routes from Astorga to the region of El Bierzo come together here: one through the pass of El Campu las Monas (Brañuelas) and the other through El Puertu Braña (Manzanal del Puerto) [160,167]. The traces of two large Roman camps can be identified on some historical aerial coverages prior to the aggressive reforestation activities carried out from 1970s onwards. Their structures have been razed to the point they cannot be detected using airborne LiDAR.

La Silva 1 is located on an elevation (1133 masl) belonging to the Sil watershed. From this location on the border between the villages of La Silva, La Granja and Tremor de Abajo, the vista over the surrounding landscape is splendid. The camp tends to form a playing-card layout, but its south-eastern side draws curves in order to avoid two depressions (Figure 13(56)). This enclosure shows a corridor entrance, a feature also documented in northwestern Iberia [23]. Another circular structure (c. $20 \mathrm{~m}$ in diameter) was documented within the site, close to its northern corner. This structure recalls a similar archaeological feature documented in the camp of Valdemeda [69].

La Silva 2 is located in a flat, elevated area (1095-1110 masl), dividing the Tuerto and Sil basins. Once again, the defensive perimeter resembles a playing card, although its northwestern side projects outwards, drawing a semi-circle (Figure 13(57)). This is an anomaly already attested in other Roman camps, such as El Chao [20] or El Picu L.lagüezos [29]. An interruption of the defensive line at this point could respond to an access to the enclosure.

Sueros

The village of Sueros is located halfway between La Silva and Astorga, on the old road that linked them through Brañuelas through the River Tuerto valley. That implies a day's walk away from both places. The Roman camp was built on an elevated plain (950 masl) $500 \mathrm{~m}$ to the $\mathrm{W}$ of the village. Terrain is suitable for a large squared, playing-card shaped enclosure like this one (Figure 13(58) and 
Figure 16A). The proposed outline of the Roman road that runs through the valley also traverses the enclosure [160].

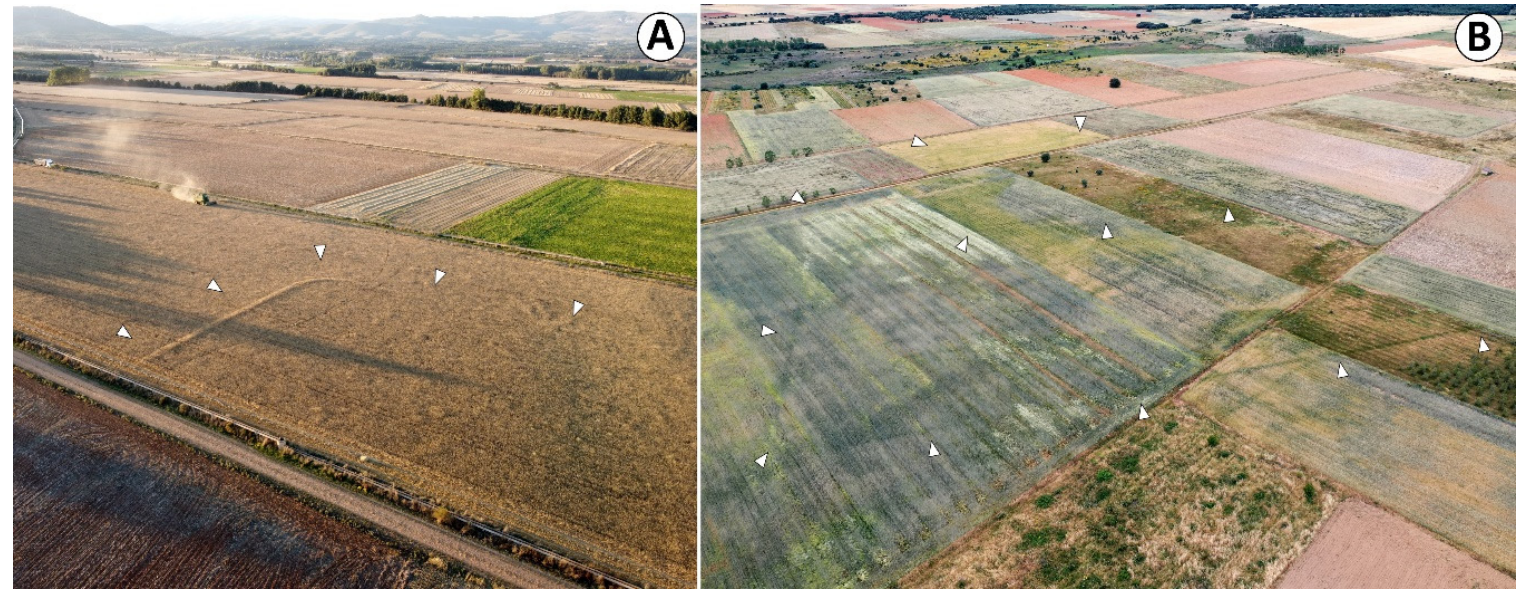

Figure 16. Oblique aerial photo of the camps of Sueros (A) and Villamontán 1 and 2 (B).

\section{Astorga Cluster}

In addition to the above-mentioned camp of Astorga, two large sites were documented to the east of the modern-day town, on the plains (840-850 masl) delimited by the River Tuerto and the channel of La Moldera. They were discovered after an inspection of the satellite images provided by Google Earth and documented again on the UAV-derived orthophotographs generated by us in June 2020 . The intense agricultural activity and its condition of periurban area have had a negative impact on both the archaeological structures and the environment, but the presence of elements of such an entity in the area can be undoubtedly linked with large-scale military operations.

La Veiga camp was built $1.4 \mathrm{~km}$ west of the town of San Román de la Vega. The degree of visibility of the archaeological traces varies due to different crops present on each land parcel (Figure 13(59)). To reconstruct its playing-card layout it was necessary to collage several aerial photographic coverages. The orientation of its major axis is W/SW-N/NE. On its southern side, an inner clavicula entrance was detected.

About $800 \mathrm{~m}$ to the south, there is another camp administratively divided between the towns of San Justo de la Vega and Astorga. Playing-card shaped, its perimeter is almost entirely recognisable through different series of aerial photography combined with UAV-derived orthophotography (Figure 13(60)). Morphologically similar to that of La Veiga, its orientation (N-S) differs.

\section{Villamontán Complex}

In 2015, several archaeological features were found south of the village of Villamontán, next to the road that linked Astorga and Braga through Chaves (iter 17) [160,168]. They are located in a flat area ( 825 masl) halfway between the valleys of La Valduerna and Jamuz. The best-documented enclosures are the two medium-sized, overlapped camps of Villamontán 1 and 2 [166] (Figure 16B). Two gaps in the defensive perimeter of the first enclosure seem to correspond to entrances, while the second one clearly shows a titulus on its northern side. In addition to these features, several alignments and a small playing-card shaped enclosure were identified in Villamontán 3. These three enclosures share the same WNW-ESE orientation.

Our review of the different aerial coverages available open access revealed two other camps within this cluster (Figure 13(64,65) and Figure 17). Two perpendicular lines connected by a rounded corner can be documented northeast of the above-mentioned features probably belonged to a large camp which may be partially lost (Villamontán 4). To the northwest, another medium-sized, playing card enclosure can be reconstructed in accordance with some cropmarks (Villamontán 5). 


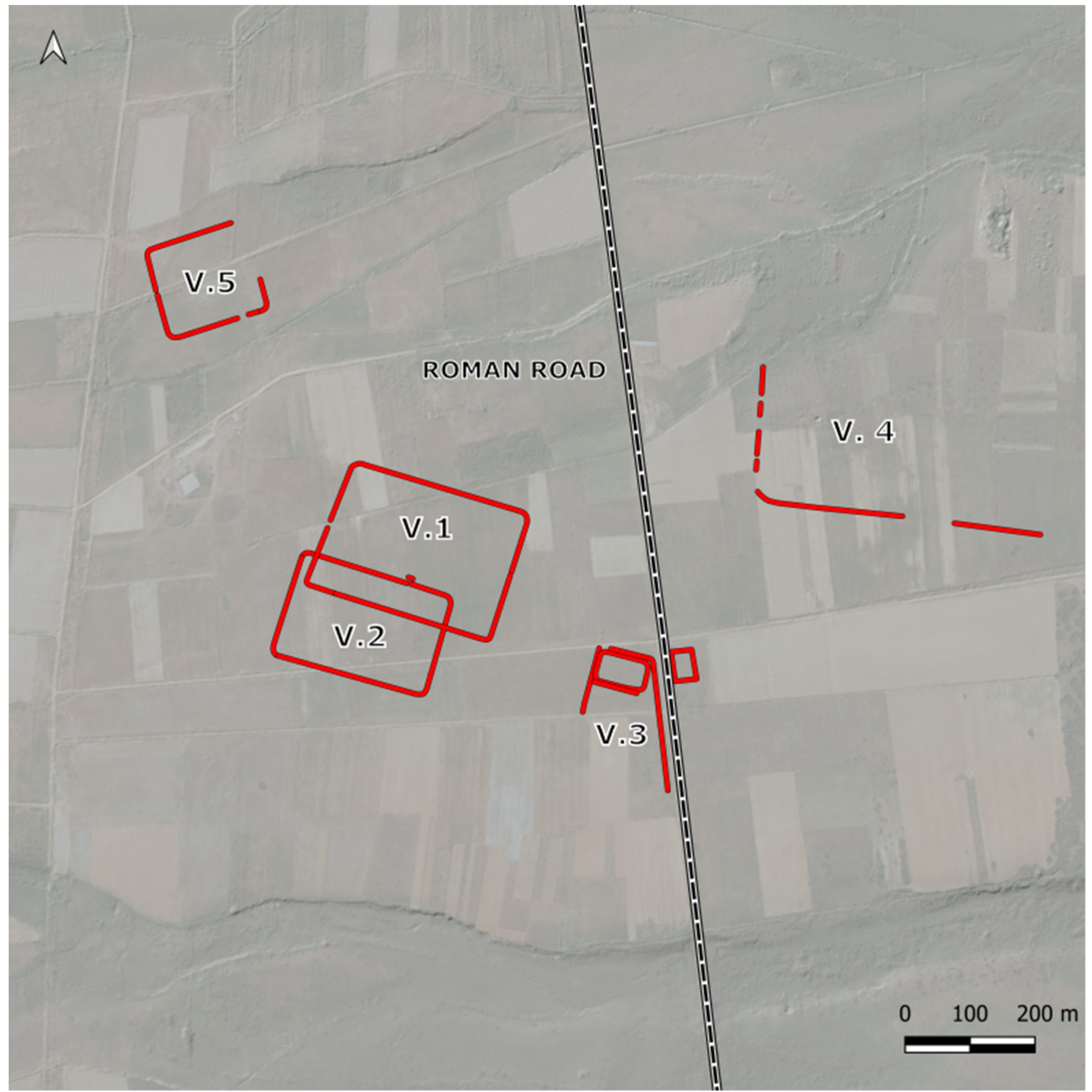

Figure 17. Archaeological enclosures (red) and Roman road (b/w) documented near Villamontán de la Valduerna. Sites 1-3 were already known, while sites 4 and 5 are recent discoveries.

\section{Garaballes}

Huerga de Garaballes is located $17 \mathrm{~km}$ southeast of Astorga, close to the point where the River Tuerto runs into the Órbigo. In this area, two alignments connected by a rounded corner on a flat plain (780 masl) were documented about $400 \mathrm{~m}$ southwest of the village (Figure 13(66)). Since the course of the River Tuerto does not allow further development of these structures and no traces could be detected on the western bank, we may consider that the watercourse was delimiting the enclosure in this area. This behaviour has been previously documented in other Roman military sites in the River Duero basin [73].

\section{Discussion}

\subsection{Defining Mobility and Settlement Patterns}

The upland areas of the Cantabrian Mountains contain the highest density of Roman camps in northwestern Iberia. In these zones, archaeological evidence shows recurrent mobility and settlement patterns following the summits of the mountain ranges [6,7]. It comes as no surprise that many of 
these routes were already in use since prehistoric times [162]. The rural communities inhabiting these territories still travel on them while moving their flocks and herds within traditional transhumance strategies [169], proving their cost-effectiveness.

In contrast, the tracking of Roman military activities in lower valleys and the northern Iberian Plateau has been challenging, as distribution maps of marching camps show $[7,17,170]$. These open landscapes have been crucial crossroads since prehistoric times, and to delve into this archaeological palimpsest is never an easy task. Besides, the data available on the Roman army in this area were scarce, fragmentary and heterogeneous. In terms of mobility, the connection of some marching camps with major Roman roads has been repeatedly stressed, and it is even possible that the locations of the former shaped the routes of the latter [168]. The proximity to rivers could also reflect their importance as mobility axes, but data scarcity did not allow us to go beyond mere hypotheses [19,40,82]. Of course, the positions partially surrounded by watercourses or close to river confluences are incredibly valuable in open areas, since these natural elements could enhance artificial defences and reinforce vulnerable sections of the perimeter [122].

The data gathered in our study allow us to dig into this debate by understanding better the settlement pattern followed by the Roman army when moving across those transitionary areas between the northern Iberian Plateau and the Cantabrian Mountains to the north, and the Leonese Massif to the west. Frequently, we documented a preference for both the valley bottoms and soft-sloped riversides for camp pitching (Figure 18). In many cases, we have to discard the general terrain flatness as a deterministic explanation, since there was higher, and sometimes more defensible, ground to choose in the vicinity. Although it is possible to point out the tactical use of watercourses in some cases (e.g., Herrera 1 and 2, Micieces, Huerga de Garaballes, La Veiga, San Justo), the choosing of these locations may also be determined by logistical or mobility reasons we are still unable to calibrate due to limited evidence available.

Of course, there are examples of military settlements where an intentional use of the local terrain serves to enhance both the defensibility and visual control of these fortifications. Matimocha and Herrera 4 were placed over elevations partially or completely bordered by steep slopes (Figures 18A and 19). La Calzada at Quintanilla de Riofresno makes intelligent use of the steep riverside slope, so the western side of the camp does not show artificial defences (Figure 6(3), Figures 7B and 8A). The heart of the massive camp in Tortolondro is a hilltop from which is possible to control the whole surrounding area (Figure 7A). Quite interestingly, both Matimocha and Tortolondro are oriented facing the ubiquitous mountain of Peña Amaya, where a Roman military outpost was placed in Augustan times [171]. These two camps could be somehow related to another nearby indigenous settlement, the oppidum of Ulaña [172].

The five Roman military sites located northwest of the province of León constitute an example of the transition between plain, open areas and mountainous landscapes (Figure 20). Starting from the surroundings of Astorga, they follow the course of the River Tuerto to end up entering the mountain range known as the Leonese Massif. These large enclosures (ca. 12-15 ha) could have been used by units similar in size, if not by the same army on the move. They may have been pinpointing a military route connecting the northern Iberian Plateau and the Bierzo area that would later became a Roman road [173], hinting at a correlation between terrain flatness and planimetric regularity (See Table 3). 

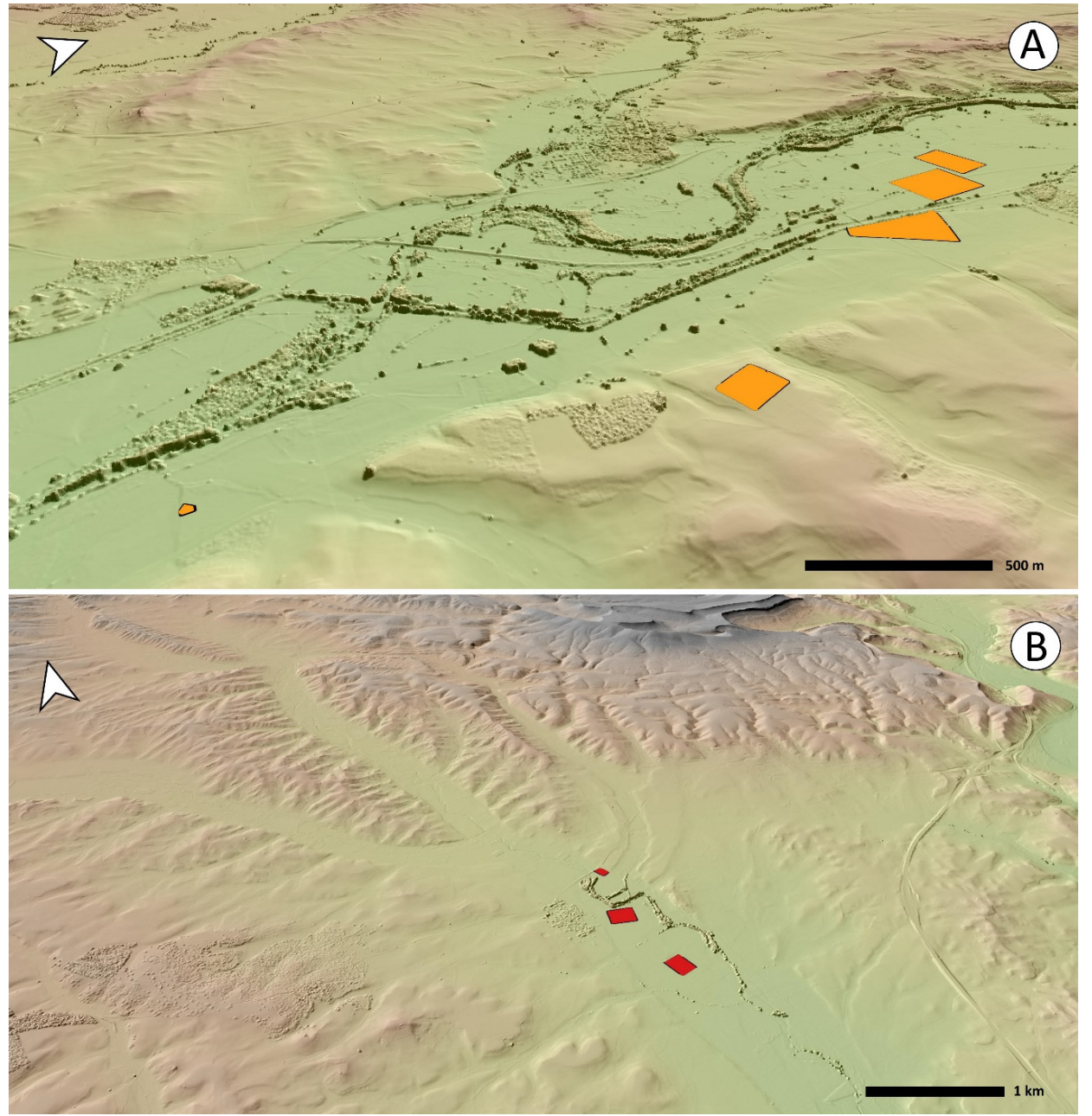

Figure 18. The recurrent use of the river valleys to set camps in Herrera de Pisuerga (A) and La Vid de Ojeda (B). Oblique 2.5D view generated using the $5 \mathrm{~m}$ LiDAR-DTM provided by the PNOA. Visualisation technique: GDAL hillshade included in the QGIS suite.

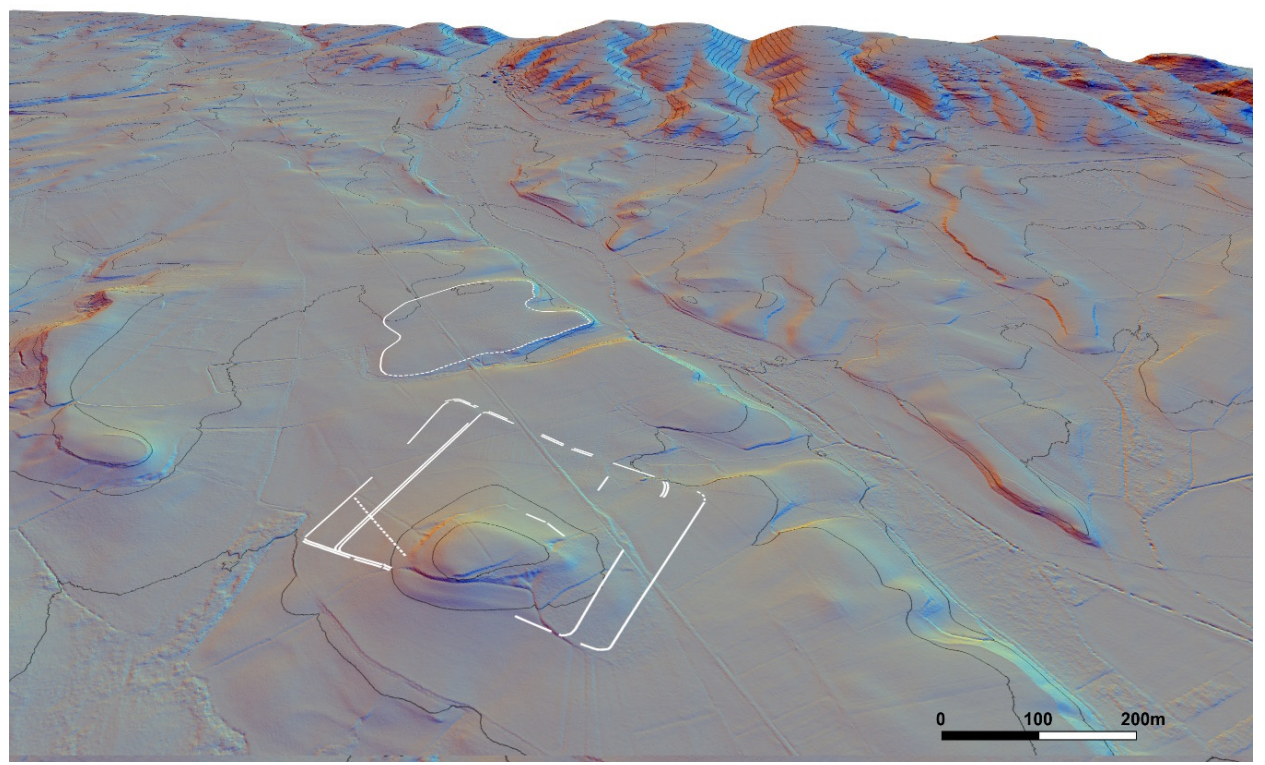

Figure 19. Tortolondro (front) and Matimocha (back) enclosures. Oblique $2.5 \mathrm{D}$ view from the $1 \mathrm{~m}$ LiDAR-DTM using the PNOA data. Visualisation technique: multi-directional hillshade RVT (ZRC SAZU). 


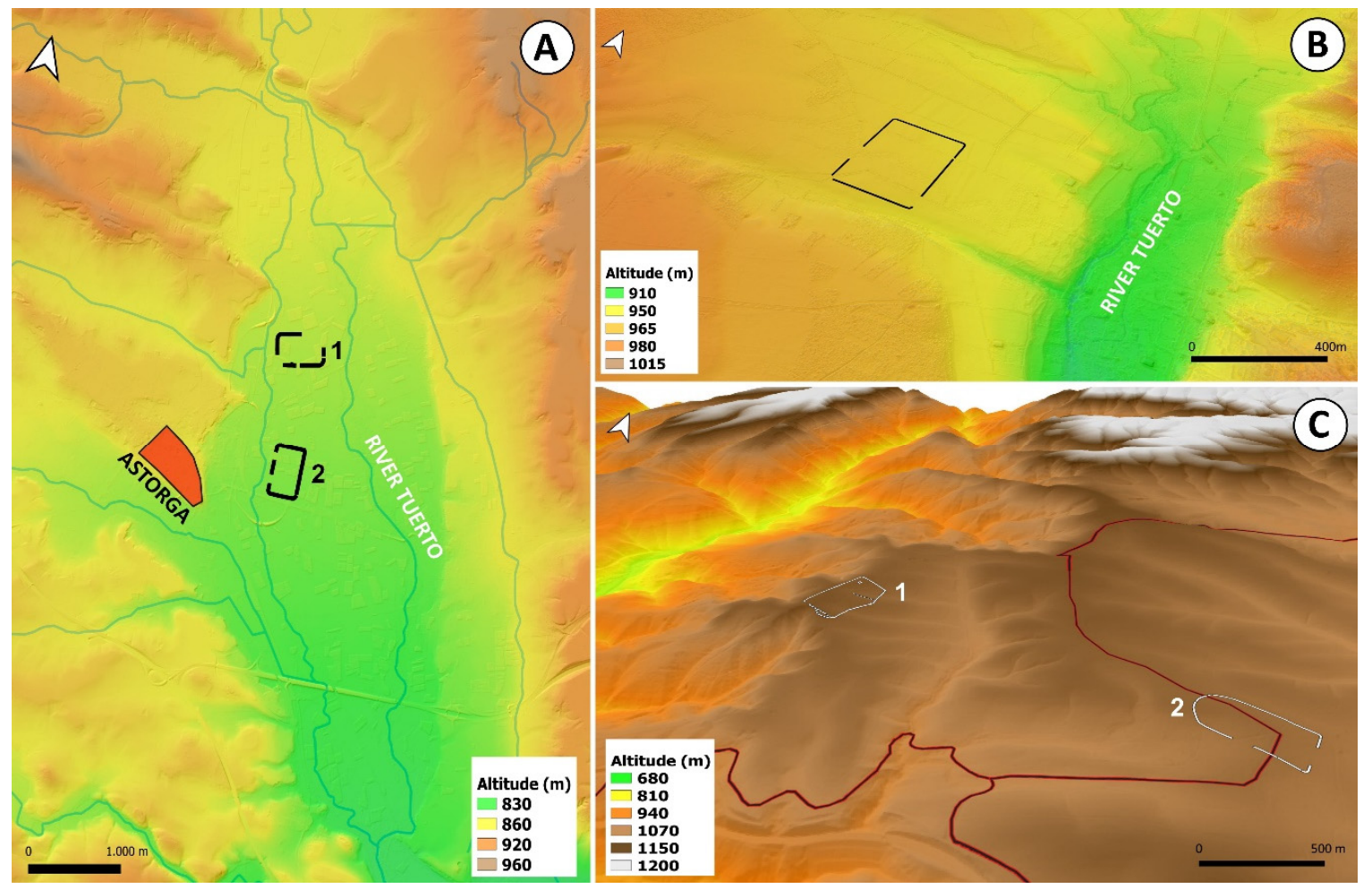

Figure 20. Different settlement patterns: (A) San Justo (1) and La Veiga (2), top view; (B) Sueros, oblique view; and (C) La Silva 1 (1) and La Silva 2 (2) close to the intersection of two Roman roads (red), oblique view.

This way, the playing-card shaped camps of La Veiga and San Justo were built in a floodplain between the River Tuerto and La Moldera Stream, a precise bottom-of-the-valley location. Further north, the squared enclosure of Sueros occupies an easily defensible position: a soft-sloped plateau that ascends towards the west and it is delimited to the north and south by tributaries of the River Tuerto. Finally, the two sites of La Silva are excellent examples of a repeatedly documented anomaly in mountainous areas of northwestern Iberia [35,122]: the adaptation of the playing-card shaped layouts to the irregular topography in an attempt to preserve enough space for tent pitching without compromising the defensive perimeter.

The overall distribution pattern of the camps is consistent in the provinces of Burgos and Palencia, as within both areas the sites are found within the main river valleys (e.g., Pisuerga, Burejo or Boedo) descending from the Cantabrian Mountains (Figure 2). Some camps (e.g., La Vid, Ligüerzana or Santa María de Mave) could be related to troops movements between the plains of the northern Spanish Plateau, where rear-guard military activity is concentrated, and the uplands of northern Castile and Cantabria, where several south-north penetration routes have been already attested [7,17]. That does not exclude the possibility of another important east-west mobility axis, as the location of sites such as Tortolondro or Páramo de Boedo could suggest.

Although the poor state of preservation in several sites of the case study makes it impossible to recreate their defensive perimeter and determine their actual size, the remaining marching camps can be classified into small (1-3.5 ha), medium (4-8 ha), large (10-15 ha) and extra-large (15+ ha) sites [6]. Considering that, we believe that the large and extra-large enclosures could have garrisoned several thousands of men, a number of troops that has to be linked with historical episodes involving massive troop deployments. Many of these sites could be related to the Augustan campaigns against Astures and Cantabri (26-19 a. C) or the years immediately after, when several legions and auxiliary units were deployed in the area $[7,174]$. However, we cannot disregard other military operations in the area during the Late Republic, episodes not always entirely transmitted by ancient written sources [175]. 
The presence of small temporary fortifications could also point out the wide range of actions carried out by the Roman army in the area during early Imperial times (namely between late 1st c. $\mathrm{BC}$ and early 1st c. AD), including infrastructure building, territorial reconstruction, and logistic or peacekeeping operations $[55,176]$. In order to define the chronology and actual purpose of these temporary sites, in-depth archaeological studies exceeding the goal for this paper are needed. Despite the efforts made by the Roman military archaeology in the last decades [177], we cannot properly track the deployment of auxiliary units in northwestern Iberia during early Imperial times. These infantry and cavalry battalions were several hundreds' strong, a number that could fit many of the smaller camps described in this paper.

Another interesting category is that of even smaller fortifications controlling the flat areas around the prominent hills in which they are located examples include: Las Pardas 1 and 2, Nestar, Matarrepudio and Oteruelo-Armunia (Figure 10(23,24)). This pattern is not uncommon when it comes to castella (small outposts) in northwestern Iberia as they prefer easily fortifiable sites with a high range of visibility from medium to long distances [122]. Matarrepudio fits with this castella pattern, while Nestar could be either a large outpost or a small camp. Similarly to Herramélluri 1 in La Rioja [80], Las Pardas 1 and 2, Valdemiranda and Oteruelo-Armunia could be considered as fortlets subsidiary to major military bases $[148,178,179]$. Although many of these enclaves could be related to the first occupation of the territory, during and after the military conquest, we cannot rule out a later chronology. The latter option may be related to the expansion and effective control of the landscape by the Roman estate within the next few years after the conquest.

\subsection{The Recurrent Use of Space}

The recurrent use of space is well documented in some areas of northwestern Iberia. For instance, the number and size of the structures identified at Herramélluri (La Rioja) correspond with an intense military activity in an area that might be an essential logistic node halfway between the Duero and Ebro basins $[19,80]$. Only three enclosures were known in Villamontán de la Valduerna to date [166], but the detection of other structures described in this paper reveals that the Roman army was rather fonder of this location than we thought. Interestingly, it is possible to reach both Astorga and Rosinos de Vidriales in a day's march following the Roman road included in the Antonine Itinerary [168]. In these sites, the archaeological record has shown traces of Roman military occupation in early Augustan times [180].

Later on, Rosinos de Vidriales became the permanent base of the legio X Gemina (ca. 20-15 BC-63 AD) and the ala II Flavia (75-late 3rd c. AD) [181,182]. This significant military presence could explain the camp cluster documented at La Chana, a relatively barren land located $8 \mathrm{~km}$ to the north of Rosinos de Vidriales following the Roman road known as iter XVII [70,72,83]. All the enclosures documented here are small (1.5-3.3 ha), and their positioning indicates that they are not synchronous elements. In fact, some of them show multiple defensive lines that are clear signs of enlargements and reductions. Similar trends and changes in legionary bases have been documented in Europe [139,183,184]. These structures reveal the interest of the Roman army in training the troops on camp building techniques (castra metatio or castra munitio) that could be of use during military campaigns.

At this point, it is important to address the surroundings of León [156,158] and Herrera de Pisuerga [143,151], known permanent military bases in early Imperial times. The clusters documented in Trobajo-San Andrés-Oteruelo and Villaquilambre are close to the legionary fortresses of the VI Victrix and VII Gemina legions (between 4 and $6 \mathrm{~km}$ away), and the majority of these enclosures are less than 2 ha in size. Their layout and disposition resemble those of practice works. Isolated camps documented at San Miguel del Camino and Sariegos seem to correspond with different military logics. The former was placed halfway between León and Astorga, close to a Roman road that is connecting those important nuclei [160]; the latter was located upstream on the River Bernesga, probably pinpointing a route that connects León with the mountain passages leading to the via Carisa, to the north of the Cantabrian Mountains [162,185]. 
Although on a less impressive scale, similar trends have been documented in Herrera de Pisuerga. We believe that the structures documented following the course of the River Pisuerga probably belong to actual camps. Some of them are too large to be considered practice works (Herrera 1, 2 and 3), while the settlement pattern in other cases leaves little room for doubt (Herrera 4). Whether they are earlier than the foundation of the base of legio III Macedonica at Herrera de Pisuerga or not is something we cannot determine at the current time. Regarding the traces documented on the plains to the southwest of Herrera de Pisuerga, their density and layout are better related to practice works. However, the settlement pattern and morphology of the enclosures of Calahorra de Boedo and Las Pardas makes them candidates for places with extended occupation.

What about clusters such as Páramo de Boedo and La Vid de Ojeda? Although we cannot discount other options, evidence points to a similar anomaly to the one documented in Villamontán de la Valduerna: the recurrent diachronic use of the same place by several military units differing in size. Current data from both Cantabria and northern Castile reveals that this area was a hotspot in early Imperial times, and the diachronic presence of fortifications at the same spot has been proved archaeologically [186]. While many of the bigger enclosures have to be linked with large-scale military operations, others could be related to low density or policing activities.

\subsection{Creating Holistic Narratives on the Roman Military Deployment in Northwestern Iberia and the Indigenous Response}

As we noted at the beginning of this paper, the latest developments in Roman military archaeology, supported by geosciences, are transforming our perceptions about the scale of Roman military deployment in northwestern Iberia. The growing evidence-expanded by the results of our research-let us to assess the huge effort invested by the Roman state to conquer, explore, and effectively control these territories between late 1st c. BC and early 1st c. AD.

The Roman army was the fundamental pillar to drive this process of expansion, as many scholars have already pointed out $[7,15,58,187,188]$. These military contingents would be at the forefront of the encounters with the local inhabitants of these territories. Therefore, the more extensive information we gather about the Roman military presence in this region, the better position we will be in to create balanced narratives about the changes produced in local social and cultural landscapes. In addition, we will be capable to explore the agency of indigenous communities in this process, taking into account their inner diversity at different levels.

Recent discussions among the scholars devoted to the Iron Age societies in this region also emphasise the existence of regionalised cultural and social traits among the indigenous communities $[8,60,61,189,190]$. Considering this may prevent us to assume a uniform narrative about the Roman conquest of northwestern Iberia [170]. Traditionally, the attitudes deployed by the Roman state towards different territories within this region were assumed to reflect a diversified 'Romanisation' process, depending on the economic or productive interests shown by the conquerors [33,191]. However, learning from postcolonial critiques $[86,87,192,193]$, we should consider a connection between these diverse attitudes and the response of local communities to the external aggression. There is a potential correlation between the different native reactions to contact with the Roman army and their diverging historical trajectories, enabling different outcomes [193]. In this regard, epigraphic documents such as the Bierzo Edict seem to reveal the existence of reward-punishment policy applied by the Roman state soon after the conquest [194].

New data gathered concerning the Roman military deployment in the study area will be relevant to fulfil these goals, although those aims are still pending tasks to be faced as soon as possible within future research initiatives. This way, we should evaluate the existence of different patterns in the Roman military deployment across the study area. Both the archaeological and spatial evidence provided by the Roman military sites, and the archaeological accounts available within the indigenous hillforts should be consider, aiming at producing holistic interpretations on the expansion of the Roman state in northwestern Iberia. 
Meanwhile, we might be able to produce some preliminary considerations concerning the spatial relationships between the Roman military sites discovered by our research and the indigenous settlements (Iron Age hillforts) located in their vicinity. Having not completed yet such study, we can observe the vast majority of the Roman camps were built disregarding the location of local indigenous sites. As we have already described, the Roman army was establishing their temporary camps in close attention to connectivity in a wide geographical scale (accessibility to wide basins/valleys connecting neighbouring regions, mountain passes, etc.), while the smaller outposts served to reinforce the control over these transit zones. Considering the 66 new sites presented in this paper, none of them seem to be showing an active role in surveilling or sieging an indigenous hillfort. In this regard, most of the evidence linked with these phenomena is also limited to the easternmost $[144,145,195-197]$ and southernmost [24] territories within our study area. In several cases, these episodes are directly linked with the assault and ulterior occupation of large hillforts -oppida- sites that played a prominent role in the articulation of the Late Iron age landscapes. This situation differs from what it is archaeologically attested in areas such as the Asturian or eastern Galicia mountains [6,35,36]; although it is possible to trace the penetration routes used by the Roman army with some ease. The transit through these territories followed the mountain ranges and was never conditioned by the presence of native settlements; these are to be found on less elevated, more habitable ground.

If we discard a strict topographic determinism -as we should- and set aside other logistic constraints, different behaviours show how the Roman army responded to the diverse ways of understanding conflict by native communities. In this sense, even the ancient Latin and Greek writers conveyed the existence of different reactions to the Roman expansion: from a coordinated military response -characteristic of proto-state societies- to guerrilla warfare solutions -typical of asymmetrical conflicts- [198].

In the plains of the northern River Duero basin these episodes of "fossilised violence" have been elusive to us so far. Is this in any way related to the settlement pattern and social organisation of the indigenous communities who inhabited this area? Is it due to a lack of a systematic archaeological approach to the last stages of the Iron Age in the region? This is a promising line of enquiry that should be accomplished considering the whole region, with clearly goes beyond our current scope with this article. However, we have to acknowledge that this is an urgent matter to narrow disciplinary boundaries between Roman Military Archaeology and the study of Iron Age, fields which are somehow distant these days within archaeological traditions in Spain [10].

\section{Conclusions: More than New Dots on A Map!}

This work has sought to map and contextualise 66 recently discovered sites that can be related to the Roman military presence in modern-day provinces of León, Burgos, Palencia and Cantabria. Roman military archaeology has recently flourished in northwestern Iberia after the methodological renovation process resulting from the confluence with other European theoretical and methodological approaches [57,199], as well as an increased access to new digital tools and geospatial datasets [6,170]. The varied landscapes found in this broad region have been a challenge for archaeological research, encouraging the development and enhancement of multi-scalar and multi-disciplinary approaches to maximise data acquisition, processing and analysis [18,200,201].

Our optimism cannot hide the fact that there is still much work to be done. We aim to build up a new research paradigm that truly values the significant contribution of geospatial data for increasing archaeological knowledge. This paper emphasizes just that, the importance of using geospatial datasets and tools to improve our understanding of the expansion of the Roman army. The development of this discipline has to be based on principles of data quality, homogeneity and representativeness. The different techniques and resources used here have repeatedly shown the potential of open-access and geospatial data, but also their limitations. In our case, LiDAR was not reliable in anthropised areas or extensively exploited agricultural lands [2,81]. Also, the data has low ground returns. High-resolution satellite coverage is rarely produced taking into account optimal 
conditions for revealing archaeology, and only a few series randomly end up on easily accessible engines and platforms such as Google Earth or Bing Maps. Even considering the full range of available datasets and the considerable potential of these landscapes for developing remote sensing approaches, the detection of archaeological features only came under particular conditions $[66,68]$. Leaving aside the fact that those datasets were not generated for archaeological purposes, the phenological phenomena answer to a crop selection strategy, as well as to soil and climate conditions. In short, what is perfectly distinguishable in one place at a given time being can be completely invisible when one of those variables changes.

The results presented in this paper are convincing proof of the critical importance of Geosciences and remote sensing approaches to expand the archaeological knowledge about the expansion of the Roman state in the Iberian Peninsula. In the last two decades, the combined use of the various remote sensing techniques and geospatial datasets described here has decisively contributed to generate a critical mass of archaeological data, big enough to shatter the old debates and theories based solely on the use of ancient literary sources, epigraphy or a traditional archaeological approach [6,7]. On the other hand, new evidence allows us to identify behaviours and patterns followed by the Roman legions, reflecting the rationale behind the Roman army deployments on the ground. Far from being mere accumulative information, these data support the development of more precise methodological guidelines, and even predictive models, for surveying other areas where similar historical phenomena took place. In the years to come, the increasing access to new geospatial datasets and the enhancement of archaeological methodologies will forever change our views on the Roman conquest of northwestern Iberia. Ultimately, this will also allow us to build a more informed and holistic historical narratives on the processes of interaction between the native communities and Rome on the western fringes of the Empire [202,203].

Author Contributions: Conceptualisation, A.M.B. and J.M.C.-G.; Methodology, A.M.B., J.G.S., J.M.C.-G., D.G.-Á. and J.F.; Data Acquisition A.M.B., J.G.S., J.F. and V.V.G.; Data Analysis, A.M.B., J.M.C.-G. and D.G.-Á.; Writing-Original Draft Preparation, A.M.B., J.G.S., J.M.C.-G. and J.F.; Writing-Review \& Editing, J.G.S., J.M.C.-G., D.G.-Á. and J.F.; Graphic Material, A.M.B., J.M.C.-G., J.G.S. and V.V.G.; Project-Management, J.G.S. and J.M.C.-G.; Supervision, J.M.C.-G. and D.G.-Á. All authors have read and agreed to the published version of the manuscript.

Funding: The Warscapes project, focused on the archaeological exploration of Sasamón and Olmillos de Sasamón and managed by J. García Sánchez and José M. Costa-García, received funding from the Autonomous Government of Castile and León (Exp. B2020/003546), and the Provincial Council of Burgos (Exp. P037500G). J. García is a postdoctoral researcher from CSIC-Junta de Extremadura (TA18060); J. M. Costa-García is a postdoctoral I2C researcher of the Autonomous Government of Galicia (Grant Agreement ED481D 2019/006). J. Fonte is funded with a Marie Skłodowska-Curie Individual Fellowship (Grant Agreement No 794048) under the European Union's Horizon 2020 research and innovation programme. D. González-Álvarez is a postdoctoral researcher at the Incipit-CSIC under the Juan de la Cierva-Formación programme, funded by the Spanish Ministry of Science (Grant agreement FJCI-2017-33731).

Acknowledgments: We are very grateful to Ignacio Ruiz Vélez for the information about Tortolondro and to Christopher Smart for helping us to add Calahorra de Boedo to the repertoire. English language and style reviewed by James Brownlee and Christopher Smart. Special thanks are due to the three anonymous reviewers for their relevant suggestions and insightful comments that greatly improved our manuscript.

Conflicts of Interest: The authors declare no conflict of interest.

\section{References}

1. Bolado del Castillo, R.; Gutiérrez Cuenca, E.; Hierro Gárate, J.Á. Las guerras cántabras. In Cántabros. Origen de un Pueblo; Ocejo Herrero, Á., Bolado del Castillo, R., Gutiérrez Cuenca, E., Hierro Gárate, J.Á., Cabria Gutiérrez, J.C., Eds.; Ediciones Tantín: Santander, Spain, 2012; pp. 95-202.

2. Costa-García, J.M.; Fonte, J. Scope and limitations of airborne LiDAR technology for the detection and analysis of Roman military sites in Northwest Iberia. In Archaeology and Geomatics. Harvesting the Benefits of 10 Years of Training in the Iberian Peninsula (2006-2015); Mayoral Herrera, V., Parcero-Oubiña, C., Fábrega-Álvarez, P., Eds.; Sidestone Press: Leiden, The Netherlands, 2017; pp. 57-73. 
3. Cordero Ruiz, T.; Cerrillo Cuenca, E.; Pereira, C. Detección de un nuevo campamento romano en las inmediaciones de Mérida mediante tecnología LiDAR. Saguntum 2017, 49, 197-201. [CrossRef]

4. Berrocal-Rangel, L.; Paniego Díaz, P.; Ruano, L.; Manglano Valcárcel, G.R. Aplicaciones LiDAR a la topografía arqueológica: El Castro de Irueña (Fuenteguinaldo, Salamanca). Cuad. Prehist. Arqueol. 2017, 43, 195-215. [CrossRef]

5. Fernández-Lozano, J.; Gutiérrez-Alonso, G.; Fernández-Morán, M.Á. Using airborne LiDAR sensing technology and aerial orthoimages to unravel roman water supply systems and gold works in NW Spain (Eria valley, León). J. Archaeol. Sci. 2015, 53, 356-373. [CrossRef]

6. Costa-García, J.M.; Fonte, J.; Gago, M. The reassessment of the Roman military presence in Galicia and Northern Portugal through digital tools: Archaeological diversity and historical problems. Mediterr. Archaeol. Archaeom. 2019, 19, 17-49. [CrossRef]

7. Peralta Labrador, E.J.; Camino Mayor, J.; Torres-Martínez, J.F. Recent research on the Cantabrian Wars: The archaeological reconstruction of a mountain war. J. Roman Archaeol. 2019, 32, 421-438. [CrossRef]

8. González Ruibal, A. The politics of identity: Ethnicity and the economy of power in Iron Age northern Iberia. In Landscape, Ethnicity and Identity in the Archaic Mediterranean Area; Cifani, G., Stoddart, S., Eds.; Oxbow Books: Oxford, UK, 2012; pp. 245-266.

9. Currás, B.X.; Sastre, I.; Orejas, A. Del castro a la civitas: Dominación y resistencia en el Noroeste hispano. In Celebração do Bimilenário de Augusto. Ad Nationes. Ethnous Kallaikon; Morais, R., Navarro Caballero, M., Eds.; Câmara Municipal de Braga: Braga, Portugal, 2016; pp. 125-135.

10. Costa-García, J.M. Rediscovering the Roman Conquest of the North-western Iberian Peninsula. In Conflict Archaeology. Materialities of Collective Violence from Prehistory to Late Antiquity; Fernández-Götz, M., Roymans, N., Eds.; Routledge: Oxford, UK, 2017; pp. 141-151.

11. Sastre Prats, I. Las Formaciones Sociales de la Asturia Romana; Ediciones Clásicas: Madrid, Spain, 2001.

12. Marín Suárez, C.; González-Álvarez, D. La romanización del occidente cantábrico: De la violencia física a la violencia simbólica. Férvedes Revis. Investig. 2011, 7, 197-206.

13. Fernández Ochoa, C.; Morillo Cerdán, Á. Astures y romanos. Claves para una interpretación historiográfica de la romanización en Asturias. In Astures y Romanos: Nuevas Perspectivas; Fernández-Tresguerres, J., Ed.; Real Instituto de Estudios Asturianos: Oviedo, Spain, 2007; pp. 11-26.

14. Sastre, I.; Currás, B.X. Aggregation and Dispersal: Rural Landscapes of the Northwestern Iberian Peninsula from the Iron Age to the Early Roman Empire. In Coming Together: Comparative Approaches to Population Aggregation and Early Urbanization; Gyucha, A., Ed.; SUNY Press: Albany, NY, USA, 2019; pp. 295-320.

15. Fernández Ochoa, C.; Morillo Cerdán, Á. La romanización atlántica: Modelo o modelos de implantación romana en el noroeste peninsular. Portugalia 2015, 36, 183-197.

16. Morillo Cerdán, Á.; Martín Hernández, E. El ejército romano en la Península Ibérica: De la 'Arqueología Filológica' a la Arqueología Militar Romana. Estud. Humaníst. Hist. 2005, 4, 177-208. [CrossRef]

17. Camino Mayor, J.; Peralta Labrador, E.; Torres Martínez, J.F. (Eds.) Las Guerras Astur-Cántabras; KRK Ediciones: Gijón, Spain, 2015.

18. Menéndez Blanco, A.; González-Álvarez, D.; Costa García, J.M.; Fonte, J.; Gago Mariño, M.; Álvarez Martínez, V. Seguindo os passos do exército romano: Uma proposta metodológica para a deteção de assentamentos militares romanos no Noroeste Peninsular. In Genius Loci: Lugares e Significados | Places and Meanings; Rosas, L., Sousa, A.C., Barreira, H., Eds.; CITCEM-Centro de Investigação Transdisciplinar «Cultura, Espaço e Memória»: Porto, Portugal, 2017; Volume 2, pp. 67-79.

19. Didierjean, F.; Morillo Cerdán, Á.; Petit-Aupert, C. Traces des guerres, traces de paix armée: L'apport de quatre campagnes de prospection aérienne dans le nord de l'Espagne. In La Guerre et ses Traces. Conflits et Sociétés en Hispanie à L'époque de la Conquête Romaine (IIIe-Ier s. a.C.); Cadiou, F., Caballero, M.N., Eds.; Ausonius: Bordeaux, France, 2014; pp. 149-179.

20. Costa-García, J.M.; Menéndez Blanco, A.; González-Álvarez, D.; Gago Mariño, M.; Fonte, J.; Blanco-Rotea, R.; Álvarez Martínez, V. The Presence of the Roman Army in North-Western Hispania: New Archaeological Data from Ancient Asturias and Galicia. In Proceedings of the 23rd International Limes Congress in Ingolstadt 2015, Ingolstadt, Germany, 12-23 September 2015; Sommer, C.S., Matešić, S., Eds.; Nünnerich-Asmus: Mainz, Germany, 2018; Volume 2, pp. 903-910. 
21. Martín Hernández, E. El Mouro. Castrametación en la vía de la Mesa (Belmonte de Miranda/Grao, Asturias). In Las Guerras-Ástur-Cántabras; Camino Mayor, J., Peralta Labrador, E., Torres Martínez, J.F., Eds.; KRK Ediciones: Gijón, Spain, 2015; pp. 239-247.

22. Martín Hernández, E.; Camino Mayor, J.; El Picu, L. lagüezos, un nuevo campamento romano en la vía Carisa. In Excavaciones Arqueológicas en Asturias 2007-2012. En el Centenario del Descubrimiento de la Caverna de La Peña de Candamo; Consejería de Educación, Cultura y Deporte del Principado de Asturias: Oviedo, Spain, 2013; pp. 267-276.

23. Costa-García, J.M.; Fonte, J.; Gago Mariño, M.; Menéndez Blanco, A.; Álvarez Martínez, V. Hallazgos arqueológicos recientes para el estudio de la presencia militar romana en el oriente gallego. Gallaecia 2017, 35, 39-70. [CrossRef]

24. Hierro Gárate, J.Á.; Vidal Encinas, J.M.; Peralta Labrador, E.; Gutiérrez Cuenca, E.; Bolado del Castillo, R. Primeras evidencias arqueológicas del asedio romano al castro de Las Labradas-El Marrón (Arrabalde, Zamora) durante el Bellum Astvricum. Estud. Humanist. Hist. 2018, 17, 1-27.

25. Vidal Encinas, J.M.; Costa-García, J.M.; González-Álvarez, D.; Menéndez Blanco, A. La presencia del ejército romano en las montañas de El Bierzo (León): Novedades arqueológicas. An. Arqueol. Cordob. 2018, 29, 85-110. [CrossRef]

26. Orejas, A.; Sánchez-Palencia, F.J.; Beltrán, A.; Ron, J.A.; López, L.F.; Currás, B.X.; Romero, D.; Zubiaurre, E.; Pecharromán, J.L.; Arboledas, L. Conquista, articulación del territorio y explotación de recursos en el límite entre el convento lucense y el de los ástures (Proyecto IVGA). In Las Guerras Astur-Cántabras; Camino Mayor, J., Peralta Labrador, E., Torres Martínez, J.F., Eds.; KRK Ediciones: Gijón, Spain, 2015; pp. 247-260.

27. Costa-García, J.M.; Menéndez Blanco, A.; Fonte, J.; Alonso Toucido, F. A Penaparda (A Fonsagrada, Lugo-Santalla, Asturias): Intervención arqueológica en un recinto campamental romano en el Occidente de la Cordillera Cantábrica. CEH 2020, 67, 45-74. [CrossRef]

28. Blanco Vázquez, L.; Suárez Manjón, P. Campamento romano de Moyapán (Allande). Actuación arqueológica. In Excavaciones Arqueológicas en Asturias 2007-2012. En el Centenario del Descubrimiento de la Caverna de La Peña de Candamo; León Gasalla, P., Ed.; Consejería de Educación, Cultura y Deporte: Oviedo, Spain, 2014; pp. 419-422.

29. Martín Hernández, E.; Camino Mayor, J. Investigaciones arqueológicas en el cordal de La Carisa. Los campamentos de L. Lagüezos y La Cuaña Carraceo. In Excavaciones Arqueológicas en Asturias 2013-2016; León Gasalla, P., Ed.; Consejería de Educación y Cultura, Principado de Asturias-Ediciones Trabe: Oviedo, Spain, 2018; pp. 293-306.

30. Camino Mayor, J. La línea de operaciones de la vía Carisa (Asturias y norte de León). In Las Guerras Astur-Cántabras; Camino Mayor, J., Peralta Labrador, E., Torres-Martínez, J.F., Eds.; KRK Ediciones: Gijón, Spain, 2015; pp. 217-237.

31. Menéndez Granda, A.; Sánchez Hidalgo, E. Campaña de sondeos arqueológicos en el campamento de época romana del Pico El Outeiro Zarrado (Taramundi-Villanueva de Oscos). In Excavaciones Arqueológicas en Asturias 2013-2016; León Gasalla, P., Ed.; Consejería de Educación y Cultura, Principado de Asturias-Ediciones Trabe: Oviedo, Spain, 2018; pp. 283-292.

32. Morillo Cerdán, Á. El territorio galaico durante las guerras cántabras: Nuevas perspectivas. In Celebração do Bimilenário de Augusto. Ad Nationes. Ethnous Kallaikon; Morais, R., Navarro Caballero, M., Eds.; Câmara Municipal de Braga: Braga, Portugal, 2016; pp. 54-72.

33. Santos Yanguas, N. La conquista de Asturias por Roma: Una nueva perspectiva. Gerión 2017, 37, 151-162. [CrossRef]

34. Orejas, A.; Sánchez-Palencia, F.J. Arqueología de la conquista del noroeste de la Península Ibérica. In II Congreso de Arqueología Peninsular: Zamora, del 24 al 27 de septiembre de 1996. Tomo IV: Arqueología Romana y Medieval; De Balbín Behrmann, R., Bueno Ramírez, P., Eds.; Universidad de Alcalá-Fundación Rei Afonso Henriques: Madrid, Spain, 1999; Volume Tomo IV, pp. 23-37.

35. Menéndez Blanco, A.; Álvarez Martínez, V.; González-Álvarez, D.; Jiménez Chaparro, J.I. La Sierra de Penouta y el cordal d'Ouroso: Una línea de avance del ejército romano en el occidente cantábrico. In Las Guerras-Ástur-Cántabras; Camino Mayor, J., Peralta Labrador, E., Torres Martínez, J.F., Eds.; KRK Ediciones: Gijón, Spain, 2015; pp. 261-268. 
36. Menéndez Blanco, A.; Costa-García, J.M.; González-Álvarez, D.; Álvarez Martínez, V.; Fonte, J. Los campamentos romanos de Cueiru y El Xuegu la Bola na vía de La Mesa. Resultaos de la campaña del 2016. In Excavaciones Arqueológicas en Asturias 2013-2016; León Gasalla, P., Ed.; Consejería de Educación y Cultura, Principado de Asturias-Ediciones Trabe: Oviedo, Spain, 2018; pp. 273-282.

37. Peralta Labrador, E. Arqueología de las Guerras Cántabras. Un campo de batalla en las sierras de Iguña y Toranzo. Revis. Arqueol. 1997, 198, 14-23.

38. Peralta Labrador, E.; Hierro Gárate, J.Á.; Gutiérrez Cuenca, E. Las monedas de los campamentos romanos de campaña de las guerras cántabras del asedio de la Loma, Castillejo y Alambre. Lucentum 2011, 30, 151-172. [CrossRef]

39. Peralta Labrador, E. La penetración del ejército romano por el interfluvio Pas-Besaya. In Las Guerras Astur-Cántabras; Camino Mayor, J., Peralta Labrador, E., Torres-Martínez, J.F., Eds.; KRK Ediciones: Gijón, Spain, 2015; pp. 131-148.

40. Vicente García, V. Los Campamentos de Campaña en el Bellum Cantabricum: Catálogo y Estado de la Cuestión. Master's Thesis, Universidad de Cantabria, Santander, Spain, 2019.

41. Blanco-Rotea, R.; Costa-García, J.M.; Fonte, J.; Gago, M.; Gonçalves, J.A. A Modern Age redoubt in a possible Roman camp. The relationship between two defensive models in Campos (Vila Nova de Cerveira, Minho Valley, Portugal). J. Archaeol. Sci. Rep. 2016, 10, 293-308. [CrossRef]

42. Tarolli, P.; Mudd, S. Remote Sensing of Geomorphology; Elsevier: Amsterdam, The Netherlands, 2020.

43. García Sánchez, J.; Costa-García, J.M. Del oppidum indígena a la ciudad romana. Evolución del paisaje de Segisamo (Sasamón, Burgos, España) a través de la fotografía aérea. Datos de la prospección aérea de 2019. Lucentum 2020, 39, 131-148. [CrossRef]

44. Menéndez Blanco, A.; González-Álvarez, D.; Álvarez Martínez, V.; Jiménez Chaparro, J.I. Propuestas de prospección de bajo coste para la detección de campamentos romanos de campaña. El área occidental de la Cordillera Cantábrica como caso de estudio. Munibe 2013, 64, 175-197.

45. Del Olmo Martín, J. Arqueología Aérea de las Ciudades Romanas en la Meseta Norte. Algunos ejemplos de urbanismo de la primera Edad del Hierro, segunda Edad del Hierro y Romanización. In Nuevos Elementos de Ingeniería Romana, III Congreso de lasObras Públicas Romanas; Junta de Castilla y León-Colegio de Ingenieros Técnicos de Obras Públicas: Astorga, Spain, 2006; pp. 313-340.

46. Campana, S. Drones in Archaeology. State-of-the-art and Future Perspectives. Archaeol. Prospect. 2017, 24, 275-296. [CrossRef]

47. Nex, F.; Remondino, F. UAV for 3D mapping applications: A review. Appl. Geomat. 2014, 6, 1-15. [CrossRef]

48. Adamopoulos, E.; Rinaudo, F. UAS-Based Archaeological Remote Sensing: Review, Meta-Analysis and State-of-the-Art. Drones 2020, 4, 46. [CrossRef]

49. Gillings, M.; Hacıgüzeller, P.; Lock, G. Archaeological Spatial Analysis: A Methodological Guide; Routledge: New York, NY, USA, 2020.

50. Verhagen, P. Spatial Analysis in Archaeology: Moving into New Territories. In Digital Geoarchaeology: New Techniques for Interdisciplinary Human-Environmental Research; Siart, C., Forbriger, M., Bubenzer, O., Eds.; Springer International Publishing: Cham, The Netherlands, 2018; pp. 11-25.

51. Mayoral Herrera, V.; Parcero-Oubiña, C.; Fábrega-Álvarez, P. Archaeology and Geomatics. Harvesting the Benefits of 10 Years of Training in the Iberian Peninsula (2006-2015); Sidestone Press: Leiden, The Netherlands, 2017.

52. Forte, M.; Campana, S. Digital Methods and Remote Sensing in Archaeology; Springer: Cham, The Netherlands, 2016.

53. Morillo Cerdán, Á. Fortificaciones campamentales de época romana en España. AESpA 1991, 64, $135-190$. [CrossRef]

54. Carretero Vaquero, S. El cuadrante noroeste peninsular en época romana: Los efectivos militares y sus establecimientos. Brigecio 1993, 3, 47-72.

55. Morillo Cerdán, Á. Conquista y estrategia: El ejército romano durante el periodo augusteo y julio-claudio en la región septentrional de la Península Ibérica. In Arqueología Militar Romana en Hispania; Morillo Cerdán, Á., Ed.; CSIC: Madrid, Spain, 2002; pp. 67-93.

56. Morillo Cerdán, Á. Los campamentos romanos de la Meseta Norte y el Noroeste: ¿un limes sin fronteras? In Los Finisterres Atlánticos en la Antigüedad: Época Prerromana y Romana; Fernández Ochoa, C., Fernández-Miranda, M., Eds.; Electra: Madrid, Spain, 1996; pp. 77-83.

57. Peralta Labrador, E. Los campamentos romanos de campaña (castra aestiva): Evidencias científicas y carencias académicas. Nivel Cero 2002, 10, 49-87. 
58. Morillo, Á.; Adroher, A.M.; Dobson, M.; Martín Hernández, E. Constructing the archaeology of the Roman conquest of Hispania: New evidence, perspectives and challenges. J. Roman Archaeol. 2020, 33, 36-52. [CrossRef]

59. Jones, R.H. Roman Camps in Britain; Amberley Publishing: Stroud, UK, 2012.

60. González-García, F.J.; Parcero-Oubiña, C.; Ayán-Vila, X. Iron Age Societies against the State: An Account of the Emergence of the Iron Age in North-Western Iberia. In Atlantic Europe in the First Millennium BC. Crossing the Divide; Moore, T., Armada, X.L., Eds.; Oxford University Press: Oxford, UK, 2011; pp. 285-301.

61. Parcero-Oubiña, C.; Criado-Boado, F. Social change, Social resistance. A long-term approach to the processes of transformation of social landscapes in the Northwest Iberian Peninsula. In The Prehistory of Iberia: Debating Early Social Stratification and the State; Cruz-Berrocal, M., García-Sanjuán, L., Gilman, A., Eds.; Routledge: New York, NY, USA, 2013; pp. 249-266.

62. Parcero Oubiña, C.; Armada Pita, X.L.; Ayán Vila, X. Castros en la escalera: El Noroeste entre la normalidad y la indiferencia. In La Protohistoria en La Península Ibérica; Celestino Pérez, S., Ed.; Itsmo: Madrid, Spain, 2017; pp. 813-878.

63. Vallori Márquez, B.; Bellón Ruíz, J.P.; Rueda Galán, C. Accampamenti, Guarnigioni e Assedi Durante la Seconda Guerra Punica e la Conquista Romana (Secoli III-I aC): Prospettive Archeologiche; Edizioni Quasar di Severino Tognon: Roma, Italy, 2019.

64. Almagro Gorbea, M. (Ed.) Historia Militar de España. Tomo I. Prehistoria y Antigüedad; Laberinto: Madrid, Spain, 2009.

65. González Ruibal, A. El desastre académico de la arqueología. In El Futuro de la Arqueología en España; Almansa, J., Ed.; JAS: Madrid, Spain, 2011; pp. 99-104.

66. Agapiou, A.; Hadjimitsis, D.; Themistocleous, K.; Papadavid, G.; Toulios, L. Detection of Archaeological Crop Marks in Cyprus Using Vegetation Indices from Landsat TM/ETM+ Satellite Images and Field Spectroscopy Measurements; SPIE: Toulouse, France, 2010; Volume 7831.

67. Ariño Gil, E.; Gurt Esparraguera, J.M.; Palet i Martínez, J.M. El pasado Presente: Arqueología de los Paisajes en la Hispania Romana; Universidad de Salamanca: Salamanca, Spain; Universitat de Barcelona: Barcelona, Spain, 2004.

68. Agapiou, A.; Lysandrou, V.; Lasaponara, R.; Masini, N.; Hadjimitsis, D.G. Study of the Variations of Archaeological Marks at Neolithic Site of Lucera, Italy Using High-Resolution Multispectral Datasets. Remote Sens. 2016, 8, 723. [CrossRef]

69. Sánchez-Palencia, F.J. El campamento romano de Valdemeda, Manzaneda (León). Numantia Arqueol. Castilla León 1986, 2, 227-234.

70. Loewinsohn, E. Una calzada y dos campamentos romanos del conuentus asturum. AESpA 1965, 38, $26-43$.

71. García Merino, C. Un nuevo campamento romano en la cuenca del Duero: El recinto campamental de Uxama (Soria). AESpA 1996, 69, 269-273. [CrossRef]

72. Del Olmo Martín, J. Arqueología aérea en tres núcleos campamentales romano de Zamora y León. Brigecio 1995, 4-5, 109-118.

73. Didierjean, F. Camps militaires romains et archéologie aérienne: Méthodologie et données nouvelles. SALDVIE 2008, 8, 95-115.

74. Del Olmo Martín, J. Arqueología aérea en Castilla y León. Patrim. Hist. Castilla León 2017, 61, 40-43.

75. Del Olmo Martín, J.; Rodríguez Jiménez, J. Arqueología Aérea en Castilla y León. Revis. Arqueol. 1993, 142, 6-7.

76. Domergue, C. L'utilisation des photographies aériennes dans l'étude des mines d'or romaines à ciel ouvert du nord-ouest de l’Espagne. Mélanges Casa Velázquez 1981, 17, 579. [CrossRef]

77. García García, M. Las Pozas (Casaseca de las Chanas, Zamora): Dos nuevos recintos de fosos calcolíticos en el Valle del Duero. Trab. Prehist. 2013, 70, 175-184. [CrossRef]

78. Ariño Gil, E.; Dahí, S.; García-García, E.; Liz Guiral, J.; Rodríguez, J.; Sala, R.; De Soto, M.R.; Tamba, R. Intensive survey in the territory of Salamanca: Aerial photography, geophysical prospecting and archaeological sampling. J. Roman Archaeol. 2015, 28, 283-301. [CrossRef]

79. Ariño Gil, E.; Didierjean, F.; Liz Guiral, J.; Sillières, P. Albocela (Villalazán, Zamora). Interpretación de la ciudad romana a partir de la fotografía aérea y la prospección intensiva. In Villes et Territoires Dans le Bassin su Douro à L'époque Romaine. Actes de la Table-Ronde Internationale (Bourdeaux, Septembre 2004); Navarro Caballero, M., Palao Vicente, J.J., Magallón, M.A., Eds.; Diffusion de Boccard: Paris, France, 2007; pp. 171-193. 
80. Ariño, E.; Ezquerro, A.; Roger, S.; González-Tablas, J.; García Sánchez, J. La ciudad de Libia (Herramélluri, España) y su territorio: Arqueología del paisaje y prospección intensiva. Agri Centuriati Int. J. Landsc. Archaeol. 2019, 16, 117-138.

81. Costa-García, J.M.; Casal García, R. Fotografía aérea histórica, satelital moderna y LiDAR aéreo en algunos recintos militares romanos de Castilla y León. Portugalia 2015, 36, 143-145.

82. Menéndez Blanco, A.; González-Álvarez, D.; Jiménez Chaparro, J.I.; Álvarez Martínez, V. Un nuevo campamento militar romano en el Páramo Leónés: Huerga de Frailes. Argutorio 2011, 26, 32-35.

83. Costa-García, J.M. Presencia militar romana en La Chana (Castrocalbón, León). Nailos 2016, 3, 47-85.

84. Sánchez-Palencia, F.J.; Currás, B.X. Campamentos romanos en zonas mineras del cuadrante noroeste de la Península Ibérica. In Las Guerras Astur-Cántabras; Camino Mayor, J., Peralta Labrador, E., Torres Martínez, J.F., Eds.; KRK Ediciones: Gijón, Spain, 2015; pp. 273-284.

85. Carman, J. Archaeologies of Conflict (Debates in Archaeology); Bloomsbury: London, UK, 2013.

86. Gardner, A. Thinking about Roman imperialism: Postcolonialism, globalization and beyond? Britannia 2013, 44, 1-25. [CrossRef]

87. Hingley, R. Globalizing Roman Culture: Unity, Diversity and Empire; Routledge: London, UK, 2005.

88. Parcak, S.; Mumford, G.; Childs, C. Using Open Access Satellite Data Alongside Ground Based Remote Sens.: An Assessment, with Case Studies from Egypt's Delta. Geosciences 2017, 7, 94. [CrossRef]

89. Luo, L.; Wang, X.; Guo, H.; Lasaponara, R.; Shi, P.; Bachagha, N.; Li, L.; Yao, Y.; Masini, N.; Chen, F.; et al. Google Earth as a Powerful Tool for Archaeological and Cultural Heritage Applications: A Review. Remote Sens. 2018, 10, 1558. [CrossRef]

90. Stek, T.D. Drones over Mediterranean landscapes. The potential of small UAV's (drones) for site detection and heritage management in archaeological survey projects: A case study from Le Pianelle in the Tappino Valley, Molise (Italy). J. Cult. Herit. 2016, 22, 1066-1071. [CrossRef]

91. Groh, S.; Sedlmayer, H. Expeditiones Barbaricae. Forschungen zu den Römischen Feldlagern von Engelharstetten, Kollnbrunn und Ruhhof, Niederösterreich; Landessammlungen Niederösterreich/Donau-Universität Krems: Krems, Austria, 2015.

92. Bernardini, F.; Vinci, G.; Horvat, J.; De Min, A.; Forte, E.; Furlani, S.; Lenaz, D.; Pipan, M.; Zhao, W.; Sgambati, A.; et al. Early Roman military fortifications and the origin of Trieste, Italy. Proc. Natl. Acad. Sci. USA 2015, 112, 1520-1529. [CrossRef] [PubMed]

93. Oltean, I.; Hanson, W. Conquest strategy and political discourse: New evidence for the conquest of Dacia from LiDAR analysis at Sarmizegetusa Regia. J. Roman Archaeol. 2017, 30, 429-446. [CrossRef]

94. Bödecker, S. Römische Übungslager im Hinterland von Bonn. In Der Limes Vom Niederrhein bis an die Donau: 6. Kolloquium der Deutschen Limeskommission; Heinrich, P., Ed.; Theiss: Stuttgart, Germany, 2012; pp. 21-27.

95. García Sánchez, J. Metodologías de prospección a escala regional y artefactual en la comarca. La prospección del Ager Segisamonensis; comarca Odra-Pisuerga (Burgos). Complutum 2013, 24, 9-28. [CrossRef]

96. Conrad, O.; Bechtel, B.; Bock, M.; Dietrich, H.; Fischer, E.; Gerlitz, L.; Wehberg, J.; Wichmann, V.; Böhner, J. System for Automated Geoscientific Analyses (SAGA) v. 2.1.4. Geosci. Model Dev. 2015, 8, 1991-2007. [CrossRef]

97. Kokalj, Ž.; Somrak, M. Why Not a Single Image? Combining Visualizations to Facilitate Fieldwork and On-Screen Mapping. Remote Sens. 2019, 11, 747. [CrossRef]

98. Mlekuž, D. Skin Deep: LiDAR and Good Practice of Landscape Archaeology In Good Practice in Archaeological Diagnostics. Non-Invasive Survey of Complex Archaeological Sites; Corsi, C., Slapšak, B., Vermeulen, F., Eds.; Springer: Cham, The Netherlands, 2013; pp. 113-129. [CrossRef]

99. Bennett, R.; Welham, K.; Hill, R.; Ford, A. A Comparison of Visualization Techniques for Models Created from Airborne Laser Scanned Data. Archaeol. Prospect. 2012, 19, 41-48. [CrossRef]

100. Štular, B.; Kokalj, Ž.; Oštir, K.; Nuninger, I. Visualization of lidar-derived relief models for detection of archaeological features. J. Archaeol. Sci. 2012, 39, 3354-3360. [CrossRef]

101. Devereux, B.J.; Amable, G.S.; Crow, P. Visualisation of LiDAR terrain models for archaeological feature detection. Antiquity 2015, 82, 470-479. [CrossRef]

102. Challis, K.; Forlin, P.; Kincey, M. A Generic Toolkit for the Visualization of Archaeological Features on Airborne LiDAR Elevation Data. Archaeol. Prospect. 2011, 19, 279-289. [CrossRef]

103. Opitz, R.; Cowley, D. Interpreting Archaeological Topography: Lasers, 3D Data, Observation, Visualisation and Applications; Oxbow: Oxford, ME, USA, 2013. 
104. Sevara, C.; Verhoeven, G.; Doneus, M.; Draganits, E. Surfaces from the Visual Past: Recovering High-Resolution Terrain Data from Historic Aerial Imagery for Multitemporal Landscape Analysis. J. Archaeol. Method Theory 2018, 25, 611-642. [CrossRef]

105. Hanson, W.; Oltean, I. (Eds.) Archaeology from Historical Aerial and Satellite Archives; Springer: Cham, The Netherlands, 2013.

106. Ivanišević, V.; Veljanovski, T.; Cowley, D.; Kiarszys, G.; Bugarski, I. (Eds.) Recovering Lost Landscapes; Institute of Archaeology-Aerial Archaeology Research Group: Belgrade, Serbia, 2015.

107. Ceraudo, G. Aerial Photography in Archaeology. In Good Practice in Archaeological Diagnostics. Non-Invasive Survey of Complex Archaeological Sites; Corsi, C., Slapšak, B., Vermeulen, F., Eds.; Springer: Cham, The Netherlands, 2013; pp. 11-30. [CrossRef]

108. Wilson, D. Air Photo Interpretation for Archaeologists; Tempus: Charleston, SC, USA, 2000.

109. Edis, J.; Macleod, D.; Bewley, R. An archaeologist's guide to classification of cropmarks and soilmarks. Antiquity 1989, 63, 112-126. [CrossRef]

110. Bewley, R.H. Aerial survey for archaeology. Photogramm. Rec. 2003, 18, 273-292. [CrossRef]

111. Evans, R.; Jones, R.J.A. Crop marks and soils at two archaeological sites in Britain. J. Archaeol. Sci. 1977, 4, 63-76. [CrossRef]

112. Sabia, C.; Masini, N.; Lasaponara, R. On the visibility of crop marks through seasons preliminary results from multi-date Google Earth pictures and ground truth. In Earth Observation: A Window on the Past; Lasaponara, R., Masini, N., Biscione, M., Hernández, M., Eds.; EARSeL: Potenza, Italy, 2013; pp. 377-388.

113. Hadjimitsis, D.G.; Themistocleous, K.; Cuca, B.; Agapiou, A.; Lysandrou, V.; Lasaponara, R.; Masini, N.; Schreier, G. Remote Sensing for Archaeology and Cultural Landscapes: Best Practices and Perspectives Across Europe and the Middle East; Springer: Cham, The Netherlands, 2019.

114. Cuesta, R.; Fiz Fernández, I.; Subías Pascual, E.; Tuset, F.; Iglesia, M.Á. Hydraulic and urban management during Roman times based on GIS and Remote Sens. analysis (Clunia, Spain). Revis. Arqueol. Ponent 2019, 29, 123-146. [CrossRef]

115. Calleja, J.F.; Requejo Pagés, O.; Díaz-Álvarez, N.; Peón, J.; Gutiérrez, N.; Martín-Hernández, E.; Cebada Relea, A.; Rubio Melendi, D.; Fernández Álvarez, P. Detection of buried archaeological remains with the combined use of satellite multispectral data and UAV data. Int. J. Appl. Earth Observ. Geoinform. 2018, 73, 555-573. [CrossRef]

116. Kalayci, T.; Lasaponara, R.; Wainwright, J.; Masini, N. Multispectral Contrast of Archaeological Features: A Quantitative Evaluation. Remote Sens. 2019, 11, 913. [CrossRef]

117. Verhoeven, G.; Doneus, M.; Briese, C.; Vermeulen, F. Mapping by matching: A computer vision-based approach to fast and accurate georeferencing of archaeological aerial photographs. J. Archaeol. Sci. 2012, 39, 2060-2070. [CrossRef]

118. Agudo, P.U.; Pajas, J.A.; Pérez-Cabello, F.; Redón, J.V.; Lebrón, B.E. The Potential of Drones and Sensors to Enhance Detection of Archaeological Cropmarks: A Comparative Study Between Multi-Spectral and Thermal Imagery. Drones 2018, 2, 29. [CrossRef]

119. Fuldain González, J.J.; Varón Hernández, F.R. NDVI Identification and Survey of a Roman Road in the Northern Spanish Province of Álava. Remote Sens. 2019, 11, 725. [CrossRef]

120. Reddé, M. Les camps militaires républicains et augustéens: Paradigmes et réalités archéologiques. SALDVIE 2008, 8, 61-71.

121. Reddé, M.; Brulet, R.; Fellmann, R.; Haalebos, J.K.; Von Schnurbein, S. Les fortifications Militaires; Ausonius: Bordeaux, France, 2006.

122. Costa-García, J.M. Roman Camp and Fort Design in Hispania: An Approach to the Distribution, Morphology and Settlement Pattern of Roman Military Sites during the Early Empire. In Proceedings of the 23rd International Limes Congress in Ingolstadt 2015, Limes XXIII, Ingolstadt, Germany, 12-23 September 2015; Sommer, C.S., Matešić, S., Eds.; Nünnerich-Asmus: Mainz, Germany, 2018; Volume 2, pp. 986-993.

123. Jones, R.H. 'Lager mit claviculae' in Britannia. In The Army and Frontiers of Rome: Papers Offered to David J. Breeze on the Occasion of his Sixty-Fifth Birthday and his Retirement from Historic Scotland; Hanson, W.S., Ed.; Society for the Promotion of Roman Studies: Portsmouth, UK, 2009; pp. 11-24.

124. Sevara, C.; Pregesbauer, M.; Doneus, M.; Verhoeven, G.; Trinks, I. Pixel versus object-A comparison of strategies for the semi-automated mapping of archaeological features using airborne laser scanning data. J. Archaeol. Sci. Rep. 2016, 5, 485-498. [CrossRef] 
125. Zingman, I.; Saupe, D.; Penatti, O.A.B.; Lambers, K. Detection of Fragmented Rectangular Enclosures in Very High Resolution Remote Sens. Images. IEEE Trans. Geosci. Remote Sens. 2016, 54, 4580-4593. [CrossRef]

126. Fiorucci, M.; Khoroshiltseva, M.; Pontil, M.; Traviglia, A.; Del Bue, A.; James, S. Machine Learning for Cultural Heritage: A Survey. Pattern Recognit. Lett. 2020, 133, 102-108. [CrossRef]

127. Driver, T.G.; Burnham, B.C.; Davies, J.L. Roman Wales: Aerial Discoveries and New Observations from the Drought of 2018. Britannia 2020. [CrossRef]

128. Waagen, J. New technology and archaeological practice. Improving the primary archaeological recording process in excavation by means of UAS photogrammetry. J. Archaeol. Sci. 2019, 101, 11-20. [CrossRef]

129. Verhoeven, G.; Sevara, C.; Karel, W.; Ressl, C.; Doneus, M.; Briese, C. Undistorting the Past: New Techniques for Orthorectification of Archaeological Aerial Frame Imagery. In Good Practice in Archaeological Diagnostics. Non-Invasive Survey of Complex Archaeological Sites; Corsi, C., Slapšak, B., Vermeulen, F., Eds.; Springer: Cham, The Netherlands, 2013; pp. 31-67.

130. Noguera, J.M.; Ble, E.; Valdés Matías, P. Metal Detecting for Surveying Marching Camps? Some Thoughts Regarding Methodology in Light of the Lower Ebro Roman Camps Project's Results. In Proceedings of the Limes XXII, 22nd International Congress of Roman Frontier Studies, Ruse, Bulgaria, September 2012; Vagalinski, L., Sharankov, N., Eds.; NAIM-BAS: Sofía, Bulgaria, 2015; pp. 853-860.

131. Bellón Ruiz, J.P.; Rueda Galán, C.; Lechuga Chica, M.Á.; Ruiz Rodríguez, A.; Molinos Molinos, M. Archaeological methodology applied to the analysis of battlefields and military camps of the Second Punic War: Baecula. Quat. Int. 2017, 435, 81-97. [CrossRef]

132. Becker, T.; Lang, A. Luftbild-Geophysik-Einzelfundkartierung. Prospektionsmassnahmen Im Bereich Der Frühkaiserzeitlichen Lager von Trebur-Geinsham. In Funde in Derl Landschaft. Neue Perpektiven Und Ergebnisse Archäologischer Prospektion; Wohlfarth, C., Keller, C., Eds.; LVR: Bonn, Germany, 2018; pp. 235-244.

133. Pisz, M.; Mieszkowski, R.; Jeczmienowski, E. Understanding the Anomaly: Multi-Method Geoscientific Research Applied on a Roman Fort in Pojejena. In New Global Perspectives on Archaeological Prospection; Bonsall, J., Ed.; Archaeopress: Oxford, UK, 2019; pp. 129-132.

134. Pisz, M.; Tomas, A.; Hegyi, A. Non-destructive research in the surroundings of the Roman Fort Tibiscum (today Romania). Archaeol. Prospect. 2020. [CrossRef]

135. Komoróczy, B.; Vlach, M.; Hüssen, C.-M.; Rajtár, J. 14C Dating of the Roman Military Interventions in the Middle Danube Barbarian World. Radiocarbon 2018, 61, 515-530. [CrossRef]

136. Jones, R.H. Roman Camps in Scotland; Society of Antiquaries of Scotland: Edinburgh, UK, 2011.

137. Maxwell, G.S. The Roman penetration of the North in the Late First Century AD. In A companion to Roman Britain; Todd, M., Ed.; Blackwell: Oxford, UK, 2004; pp. 75-90.

138. Davies, J.L.; Jones, R.H. Roman Camps in Wales and the Marches; University of Wales Press: Cardiff, UK, 2006.

139. Richardson, A. Theoretical Aspects of Roman Camp and Fort Design; Archaeopress: Oxford, UK, 2004.

140. Reddé, M. Titulum et clavicula. À propos des fouilles récentes d'Alésia. Revue Archéol. de l'Est et du Centre-Est 1995, 46, 349-356.

141. Henderson, A.A.R.; Keppie, L.J.F. Titulus or Titulum? Britannia 1987, 18, 281-284. [CrossRef]

142. García Sánchez, J. Arqueología y Paisaje en el Noroeste de Burgos: La Transición de la Segunda Edad de Hierro a época Romana a Través del Registro Material; UC-Tesis Doctoral Inédita: Santander, Spain, 2012.

143. Gómez-Pantoja, J.L. Legio IIII Macedonica. In Les Légions de Rome sous le Haut-Empire: Actes du Congrès de Lyon (17-19 September 1998); Le Bohec, Y., Wolff, C., Eds.; De Boccard: Paris, France, 2000; Volume I, pp. 104-117.

144. Peralta Labrador, E. La revisión de las guerras cántabras: Novedades arqueológicas en el norte de Castilla. In Arqueología Militar Romana en Hispania II: Producción y Abastecimiento en el Ámbito Militar; Morillo Cerdán, Á., Ed.; Universidad de León: León, Spain, 2006; pp. 523-547.

145. Fernández-Götz, M.; Torres-Martínez, J.F.; Martínez Velasco, A. The Battle at Monte Bernorio and the Augustan Conquest of Cantabrian Spain. In Conflict Archaeology. Materialities of Collective Violence from Prehistory to Late Antiquity; Fernández-Götz, M., Roymans, N., Eds.; Routledge: Oxford, UK, 2017; pp. 127-140.

146. García Alonso, M. El campamento de campaña de El Cincho (Campóo de Yuso, Cantabria). El yacimiento revisitado. In Las Guerras Astur-Cántabras; Camino Mayor, J., Peralta Labrador, E., Torres Martínez, J.F., Eds.; KRK Ediciones: Gijón, Spain, 2015; pp. 149-158.

147. Moreno Gallo, I. Vía romana de Segisamone a Pisoraca (de Sasamón a Herrera de Pisuerga). In Vías Romanas en Castilla y León; de Castilla y León, J., Ed.; Junta de Castilla y León: Valladolid, Spain, 2011; pp. 2-28. 
148. Burnham, B.C.; Davies, J.L. (Eds.) Roman frontiers in Wales and the Marches; Royal Comission on the Ancient and Historical Monuments of Wales: Aberystwyth, UK, 2010.

149. Moreno Gallo, I. Descripción de la Vía Romana de Italia a Hispana en Las Provincias de Burgos y Palencia; Excma. Diputación de Burgos-Excma. Diputación de Palencia: Salamanca, Spain, 2001.

150. Morillo Cerdán, Á.; Pérez González, C.; Illarregui Gómez, E. Herrera de Pisuerga (Palencia). Introducción histórica y arqueológica. Los asentamientos militares. In Los Campamentos Romanos en Hispania (27 a.C.-192 d.C): El Abastecimiento de Moneda; García-Bellido, M.P., Ed.; CSIC-Instituto Histórico Hoffmeyer-Instituto de Historia-Polifemo: Madrid, Spain, 2006; Volume I, pp. 305-323.

151. Illarregui Gómez, E. Acerca de los campamentos altoimperiales de Herrera de Pisuerga y su entorno. In Arqueología Militar Romana en Hispania; Morillo Cerdán, Á., CSIC, Eds.; Polifemo: Madrid, Spain, 2002; pp. 155-166.

152. Gómez Barreiro, M.; Morillo Cerdán, Á. Moneda romana y establecimientos durante las guerras cántabras y el siglo I d. C.: El registro estratigráfico de Herrera de Pisuerga (Palencia). Saldvie Estud. Prehist. Arqueol. 2008, 8, 139-151.

153. Gamarra Caballero, J.M. El alto valle del Pisuerga en época romana. Publ. Inst. Tello Téllez Men. 1988, 59, 241-296.

154. Bolado del Castillo, R.; Fernández Vega, P.Á.; Callejo Gómez, J. El recinto fortificado de El Pedrón (Cervatos, Cantabria), los campamentos de La Poza (Campoo de Enmedio, Cantabria) y el castro de Las Rabas (Cervatos, Cantabria): Un nuevo escenario de las Guerras Cántabras. Kobie 2010, 29, 85-108.

155. Peralta Labrador, E. Campamentos romanos en Cantabria. Castillos Esp. 2011, 161-163, 23-26.

156. Morillo Cerdán, Á.; García Marcos, V. The Roman Camps at León (Spain): State of the research and new approaches. In Limes XX. Estudios Sobre la Frontera Romana; Morillo Cerdán, Á., Hanel, N., Martín Hernández, E., CSIC, Eds.; Polifemo: Madrid, Spain, 2009; Volume I, pp. 389-406.

157. Morillo Cerdán, Á. Sistemas defensivos en los campamentos romanos de León. In V Congreso de Obras Públicas Romanas. Las Técnicas y las Construcciones en la Ingeniería Romana; Colegio de Ingenieros Técnicos de Obras Públicas de Madrid: Córdoba, Spain, 2010; pp. 463-477.

158. Morillo Cerdán, Á.; García Marcos, V. Legio VII Gemina and its Flavian fortress at León. J. Roman Archaeol. 2003, 16, 275-286. [CrossRef]

159. Camino Mayor, J. La Vía Asturica Augusta-Legio a Flavionavia por el Puerto de La Mesa; KRK Ediciones: Oviedo, Spain, 2018.

160. Moreno Gallo, I. Vías romanas de Astorga. In Nuevos Elementos de Ingeniería Romana, III Congreso de lasObras Públicas Romanas; Junta de Castilla y León-Colegio de Ingenieros Técnicos de Obras Públicas: Astorga, Spain, 2006; pp. 23-65.

161. Moreno Gallo, I. Vías Romanas en Castilla y León. Available online: http://www.viasromanas.net/ (accessed on 23 May 2014).

162. González-Álvarez, D. Vías romanas de montaña entre Asturias y León: La integración de la «Asturia transmontana» en la red viaria de Hispania. Zephyrus Revis. Prehist. Arqueol. 2011, 67, 171-192.

163. González-Álvarez, D.; Menéndez Blanco, A.; Álvarez Martínez, V.; Jiménez Chaparro, J.I. Los campamentos romanos de El Mouru (Grau-Miranda, Asturias) en la vía de La Mesa. BSAA Arqueol. Bol. Semin. Estud. Arqueol. 2011, 77-78, 245-267.

164. Camino Mayor, J.; Estrada García, R.; Viniegra Pacheco, Y. El campamento romano de la Vía Carisa en Asturia Transmontana. Esp. Tiempo Form. Ser. I Prehist. Arqueol. 2001, 1, 261-276. [CrossRef]

165. González Fernández, M.L. La Fortificación Campamental de Asturica Augusta; Ayuntamiento de Astorga: Astorga, Spain, 1997.

166. Celis Sánchez, J.; Valderas, A.; Muñoz Villarejo, F.A. Localización de un nuevo conjunto de campamentos romanos (Castra Aestiva) en la Vía XVII. In V Jornadas de Jóvenes Investigadores del Valle del Duero; Álvarez Rodríguez, A., Tejedor Rodríguez, C., García Vázquez, I., Eds.; Glyphos: Valladolid, Spain, 2015.

167. Mañanes Pérez, T. Arqueología de la Cuenca Leonesa del Río Sil (Laceana, Bierzo, Cabrera); Universidad de Valladolid: Valladolid, Spain, 1988.

168. Parcero Oubiña, C.; Fonte, J.; Costa-García, J.M. A GIS-based analysis of the rationale behind Roman roads. The case of the so-called via XVII (NW Iberian Peninsula). Mediterr. Archaeol. Archaeom. 2017, 17, 163-189. [CrossRef] 
169. González-Álvarez, D. Traditional Pastoralism in the Asturian Mountains: An Ethnoarchaeological View on Mobility and Settlement Patterns. In Ethnoarchaeology: Current Research and Field Methods, Proceedings of the Conference Proceedings, Rome, Italy, 13-14 May 2010; Lugli, F., Stoppiello, A.A., Biagetti, S., Eds.; Archaeopress: Oxford, UK, 2013; pp. 202-208.

170. González-Álvarez, D.; Costa-García, J.M.; Menéndez Blanco, A.; Fonte, J.; Álvarez Martínez, V.; Blanco-Rotea, R.; Gago Mariño, M. La presencia militar romana en el noroeste ibérico hacia el cambio de era: Estado actual y retos de futuro. In Accampamenti, Guarnigioni e Assedi Durante la Seconda Guerra Punica e la Conquista Romana (Secoli III-I aC): Prospettive Archeologiche; Vallori Márquez, B., Bellón Ruíz, J.P., Rueda Galán, C., Eds.; Edizioni Quasar di Severino Tognon: Roma, Italy, 2019; pp. 127-138.

171. Quintana López, J. El Castro de Peña Amaya (Amaya, Burgos): Del Nacimiento de Cantabria al de Castilla; Sautuola: Santander, Spain, 2017.

172. López Noriega, P.; Cisneros Cunchillos, M. (Eds.) El Castro de La Ulaña (Humada, Burgos): La Documentación Arqueológica (1997-2001); Universidad de Cantabria: Santander, Spain, 2005.

173. Moreno Gallo, I. Vías Romanas en Castilla y León; Junta de Castilla y León: Valladolid, Spain, 2011.

174. Peralta Labrador, E. Las Guerras Cántabras. In Historia Militar de España. Tomo I. Prehistoria y Antigüedad; Almagro Gorbea, M., Ed.; Laberinto: Madrid, Spain, 2009; pp. 247-265.

175. Amela Valverde, C. Triunfos en Hispania a finales de la República (36-27 a. C.). Iberia 2006, 9, $49-61$.

176. Lostal Pros, J. Lostal Pros, J. Los miliarios de la via romana de las Cinco Villas y del Pirineo aragonés. In Item a Caesarea Augusta Beneharno: La Carretera Romana de Zaragoza al Bearn; Moreno Gallo, I., Ed.; Centro de Estudios de las Cinco Villas: Ejea de los Caballeros, Spain, 2009; pp. 191-237.

177. Morillo Cerdán, Á. The augustean spanish experience: The origin of limes system? In Limes XX. Estudios Sobre la Frontera Romana; Morillo Cerdán, Á., Hanel, N., Martín Hernández, E., CSIC, Eds.; Polifemo: Madrid, Spain, 2009; Volume I, pp. 239-251.

178. Symonds, M. Protecting the Roman Empire: Fortlets, Frontiers, and the Quest for Post-Conquest Security; Cambridge University Press: Cambridge, UK, 2017. [CrossRef]

179. Visy, Z. Towers and Fortlets. In The Roman Army in Pannonia. An Archaeological Guide of the Ripa Pannonica; Visy, Z., Ed.; Teleki László Foundation: Pécs, Hungary, 2003; pp. 164-180.

180. García Marcos, V.; Morillo Cerdán, Á. Notas sobre la terra sigillata itálica procedente de León y Astorga: Nuevos datos cronológicos y productivos. Lancia Revis. Prehist. Arqueol. Hist. Antigua Noroeste Penins. 2003, 3, 141-151.

181. Carretero Vaquero, S. Petavonivm (Rosinos de Vidriales, Zamora). Introducción histórica y arqueológica. In Los Campamentos Romanos en Hispania (27 a.C.-192 d.C): El Abastecimiento de Moneda; García-Bellido, M.P., Ed.; CSIC-Instituto Histórico Hoffmeyer-Instituto de Historia-Polifemo: Madrid, Spain, 2006; Volume I, pp. 171-194.

182. Carretero Vaquero, S. El Campamento Romano del Ala II Flavia en Rosinos de Vidriales. La cerámica; Instituto de Estudios Zamoranos 'Florián de Ocampo': Zamora, Spain, 2000.

183. Philpott, R.A. New Evidence from Aerial Reconnaissance for Roman Military Sites in Cheshire. Britannia 1998, 29, 341-353. [CrossRef]

184. Bödecker, S. Ein Übungslagerareal im Hochwald bei Uedem. Der Limes 2013, 7, 10-13.

185. Camino Mayor, J.; Martín Hernández, E. La Carisa and the Conquest of Asturia Transmontana (Hispania) by Publius Carisius. In Proceedings of the 22nd International Congress of Roman Frontier Studies, Ruse, Bulgaria, September 2012; Vagalinski, L., Sharankov, N., Eds.; National Archaeological Institute: Sofia, Bulgaria, 2015.

186. Cepeda Ocampo, J.J.; Jiménez Chaparro, J.I. Los campamentos de La Poza y el Castro de Las Rabas revisitados. Campoo de Enmedio, Cantabria. In Las Guerras Astur-Cántabras; Camino Mayor, J., Peralta Labrador, E., Torres Martínez, J.F., Eds.; KRK Ediciones: Gijón, Spain, 2015; pp. 169-181.

187. Orejas, A.; Sánchez-Palencia, F.J.; Plácido Suárez, D. La arqueología de una conquista. In Las Médulas (León). Un Paisaje Cultural en la "Asturia Augustana"; Sánchez-Palencia, F.J., Ed.; Instituto Leónes de Cultura: León, Spain, 2000; pp. 109-136.

188. González Ruibal, A.G. Poder y comunidad en el Noroeste de la Península Ibérica (1200 a. C.-50 d. C.). Brigantium 2007, 18-19, 277-692.

189. González-García, F.J. Exploring Alternative Pathways to Social Complexity in the European Iron Age: The Northwestern Iberian Peninsula as a Case Study. Camb. Archaeol. Journey 2017, 27, 295-311. [CrossRef]

190. González-García, F.J. From cultural contact to conquest: Rome and the creation of a tribal zone in the North-western Iberian Peninsula. Greece Rome 2011, 58, 184-194. [CrossRef] 
191. Arias Vilas, F. A romanización de Galicia; A Nosa Terra: Vigo, Spain, 1992.

192. Van Dommelen, P. Postcolonial archaeologies between discourse and practice. World Archaeol. 2011, 43, 1-6. [CrossRef]

193. Parcero-Oubiña, C.; Armada, X.-L.; Nión, S.; González Insua, F. All together now (or not). In Change, Resistance and Resilience in the NW Iberian Peninsula in the Bronze Age-Iron Age transition; Currás, B.X., Sastre, I., Eds.; Routledge: London, UK, 2020; pp. 151-175. [CrossRef]

194. Sánchez-Palencia, F.J.; Mangas, J. (Eds.) El edicto del Bierzo: Augusto y el Noroeste de Hispania; Fundación las Médulas: Ponferrada, Spain, 2000.

195. Torres Martínez, J.F.; Serna Gancedo, A.; Domínguez Solera, S.D. El ataque y destrucción del oppidum de Monte Bernorio (Villarén, Palencia) y el establecimiento del castellum romano. Habis 2011, 42, 127-149.

196. Peralta Labrador, E. El asedio romano del Castro de la Espina del Gallego (Cantabria) y el problema de Aracelium. Complutum 1999, 10, 195-212.

197. Torres-Martínez, J.F.; Fernández-Götz, M.; Martínez-Velasco, A.; Vacas-Madrid, D.; Rodríguez-Millán, E. From the Bronze Age to the Roman Conquest: The Oppidum of Monte Bernorio (Northern Spain). Proc. Prehist. Soc. 2016, 82, 363-382. [CrossRef]

198. Costa-García, J.M. Las campañas augusteas en el Noroeste peninsular: Acción militar y propaganda. Revis. Arkeogazte 2015, 5, 95-111.

199. Morillo Cerdán, Á.; Aurrecoechea, J. (Eds.) The Roman Army in Hispania; Univesidad de León: León, Spain, 2006.

200. Fernández-Lozano, J.; Palao-Vicente, J.J.; Blanco-Sánchez, J.A.; Gutiérrez-Alonso, G.; Remondo, J.; Bonachea, J.; Morellón, M.; González-Díez, A. Gold-bearing Plio-Quaternary deposits: Insights from airborne LiDAR technology into the landscape evolution during the early Roman mining works in north-west Spain. J. Archaeol. Sci. Rep. 2019, 24, 843-855. [CrossRef]

201. Vidal Encinas, J.M. La aportación de las infraestructuras de datos espaciales al conocimiento de nuevos sitios castreños en la provincia de León. Férvedes 2015, 8, 25-34.

202. Millett, M. Roman Interaction in North-Western Iberia. Oxf. J. Archaeol. 2001, 20, 157-170. [CrossRef]

203. Hanson, W.S. Zones of interaction: Roman and native in Scotland. Antiquity 2002, 76, 834-840. [CrossRef]

Publisher's Note: MDPI stays neutral with regard to jurisdictional claims in published maps and institutional affiliations.

(C) 2020 by the authors. Licensee MDPI, Basel, Switzerland. This article is an open access article distributed under the terms and conditions of the Creative Commons Attribution (CC BY) license (http://creativecommons.org/licenses/by/4.0/). 